INHIBITION OF DRUG RESISTANCE IN TWO CANCER CELL LINES (MDR AND A2780CIS) IN VITRO; AND THE ROLE OF SELECTED SINGLE NUCLEOTIDE POLYMORPHISMS IN CANCER

Ph.D. Thesis

Julianna Serly, M.Sc. 


\title{
INHIBITION OF DRUG RESISTANCE IN TWO CANCER CELL LINES (MDR AND A2780CIS) IN VITRO; AND THE ROLE OF SELECTED SINGLE NUCLEOTIDE POLYMORPHISMS IN CANCER
}

\author{
Ph.D. Thesis
}

Julianna Serly, M.Sc.

Supervisor: József Molnár, M.D., Ph.D., D.Sc.

Department of Medical Microbiology and Immunobiology

Faculty of Medicine

University of Szeged

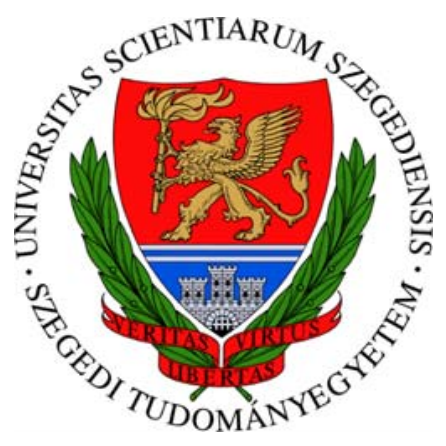

Szeged

2012 
"Perfect as the wing of a bird may be, it will never enable the bird to fly if unsupported by the air. facts are the air of science.

Without them a man of science can never rise."

Qvan Petrovich Oavlov (1849-1936) 


\section{TABLE OF CONTENTS}

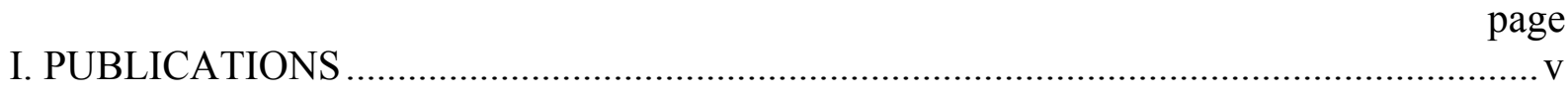

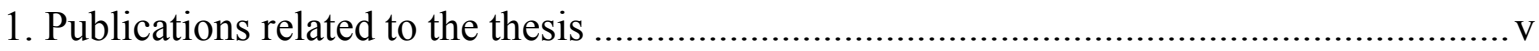

2. Publications not directly related to the thesis .................................................................... vi

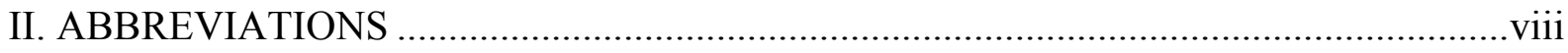

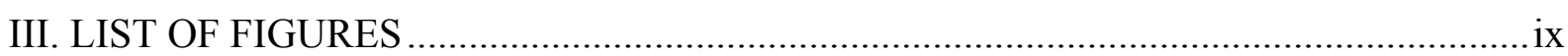

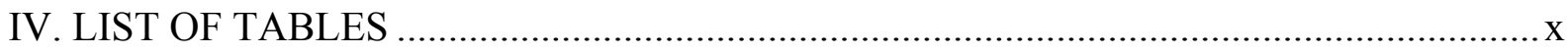

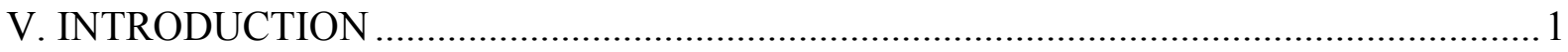

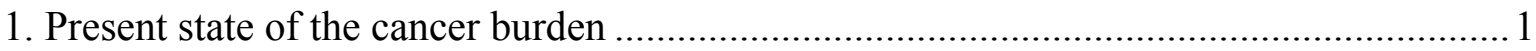

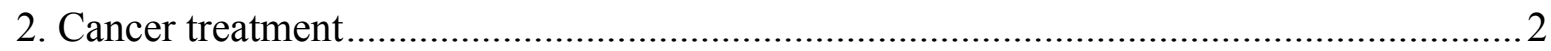

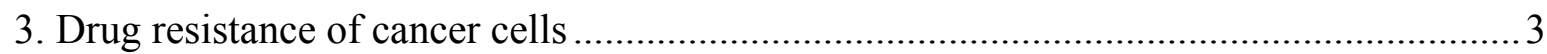

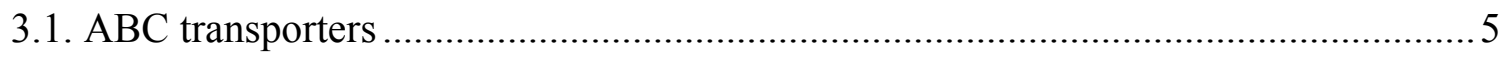

3.2. Copper transporters in cisplatin resistance ........................................................ 9

4. Association between SNPs and diseases of genetic origin........................................ 14

5. Background of the thesis: from cancer drug resistance to single nucleotide

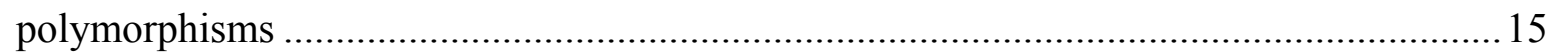

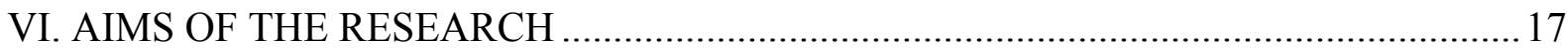

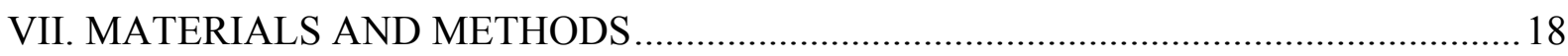

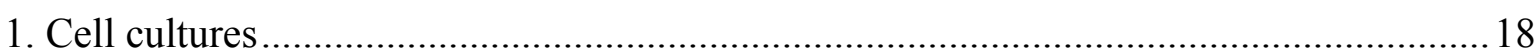

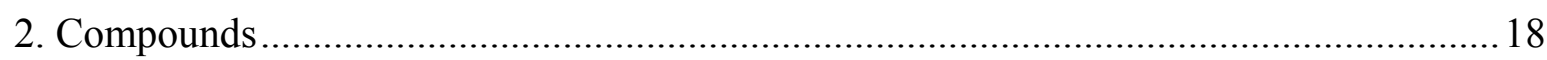

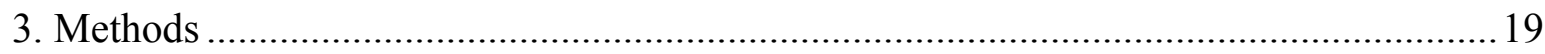

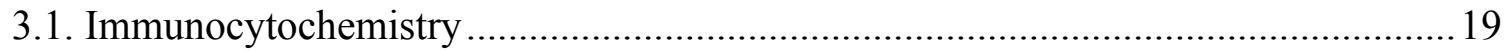

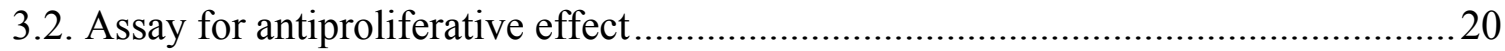

3.3. Assay for reversal of MDR in tumor cells by flow cytometry ...............................20

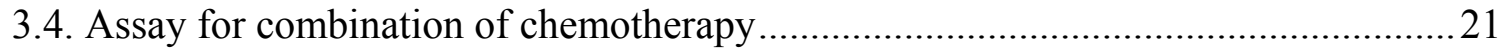

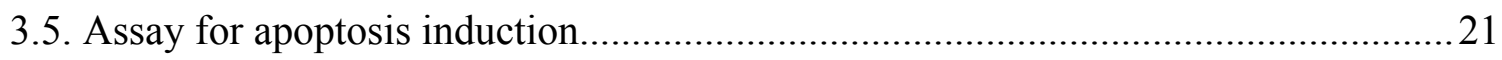

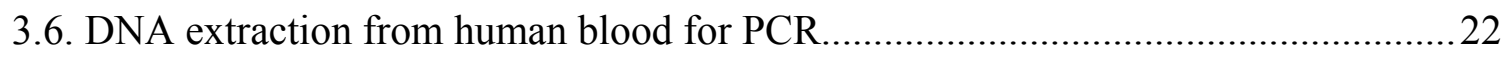

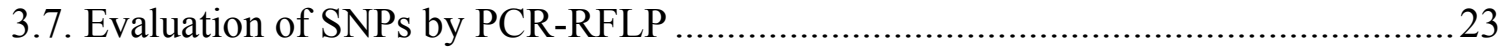

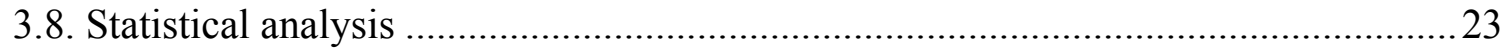

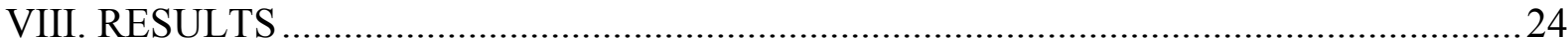




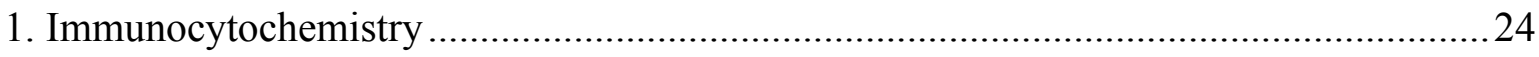

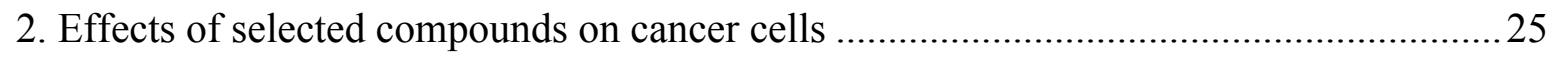

2.1. Antiproliferative effect of different compounds on MDR and A2780cis cells.........25

2.2. Effects of selected compounds on drug resistance in A2780cis and MDR cells......30

2.3. Effects of selected compounds in combination with cisplatin or doxorubicin, in A2780cis or MDR cells, respectively.

2.4. Effects of selected steroid-copper and -platinum complexes on apoptosis induction

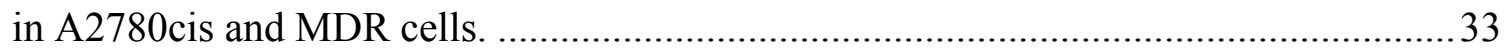

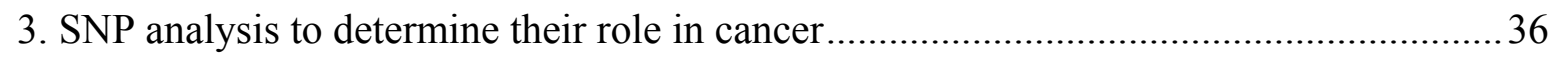

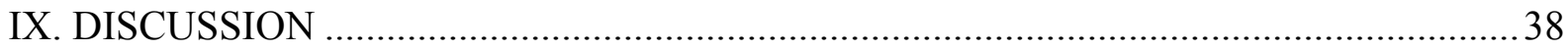

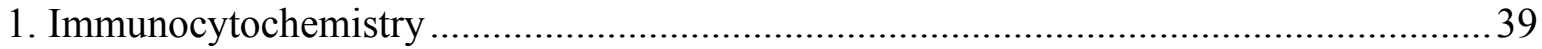

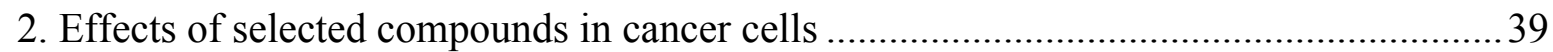

2.1. Semisubstituted steroids and selected platinum and copper complexes (I)...............39

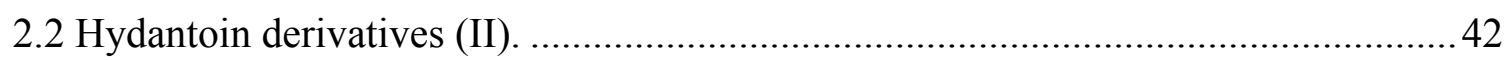

2.3. Steroidal alkaloids of Veratrum and Peganum species (III, IV)................................. 43

2.4. Saponins and phenolic components of Tribulus terrestris and Smilax excelsa (V). . 44

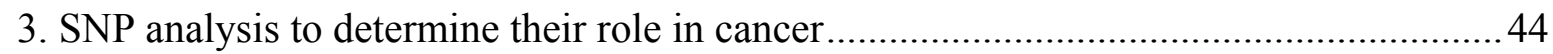

X. NEW SCIENTIFIC RESULTS RELATED TO THE THESIS ..........................................46

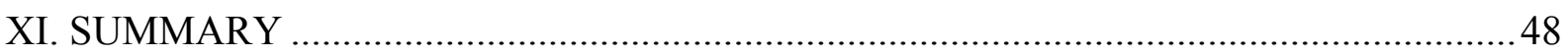

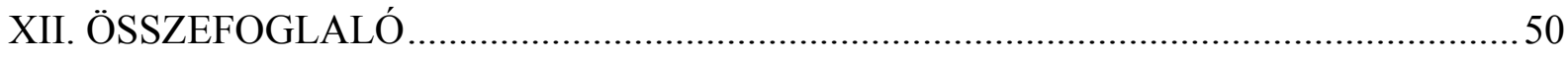

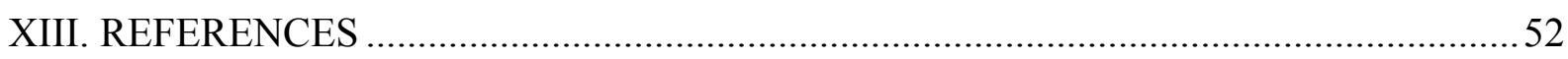

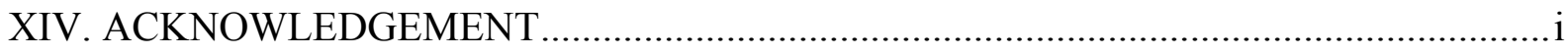

XV. FINANCIAL SUPPORT …………………………........................................i

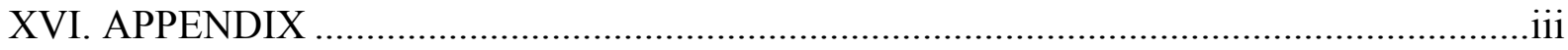

XVII. PUBLICATIONS ............................................................................................ii 


\section{PUBLICATIONS}

\section{Publications related to the thesis}

I. Serly, J.; Vincze, I.; Somlai, Cs.; Hodoniczki, L.; Molnár, J. Synthesis and comparison of the antitumor activities of steroids on $\mathrm{ABCB} 1$-transfected mouse lymphoma and human ovary carcinoma. Lett. Drug Des. Dis., 2011, 8: 138-147. IF: 0.668

II. Spengler, G.; Evaristo, M.; Handzlik, J.; Serly, J.; Molnár, J.; Viveiros, M.; KiecKononowicz, K.; Amaral, L. Biological activity of hydantoin derivatives on Pglycoprotein (ABCB1) of mouse lymphoma cells. Anticancer Res., 2010, 30: 48674871.

IF: 1.656

III. Christov, V.; Mikhova, B.; Ivanova, A.; Serly, J.; Molnár, J.; Selenge, D.; Solongo, A.; Kostova, N.; Gerelt-Od, Y.; Dimitrov, D. Steroidal alkaloids of Veratrum lobelianum Bernh. and Veratrum nigrum L. Z. Naturforsch. C., 2010, 65c: 195-200. IF: 0.718

IV. Ivanova, A.; Serly, J.; Christov, V.; Stamboliyska, B.; Molnár, J. Alkaloids derived from genus Veratrum and Peganum of Mongolian origin as multidrug resistance inhibitors of cancer cells. Fitoterapia, 2011, 85: 570-575.

IF: 1.899

V. Ivanova, A.; Serly, J.; Dinchev, D.; Ocsovszki, I.; Kostova, I.; Molnár, J. Screening of some saponins and phenolic components of Tribulus terrestris and Smilax excelsa as MDR modulators. In Vivo, 2009, 23: 545-550.

IF: 1.171

\section{$\Sigma I F=6.112$}




\section{Publications not directly related to the thesis}

I. Molnár, J.; Serly, J.; Pusztai, R.; Vincze, I.; Molnár, P.; Horváth, Gy.; Deli, J.; Maoka, T.; Zalatnai, A.; Enjo, F.; Tokuda, H.; Nishino, H. Putative supramolecular complexes formed by carotenoids and ascorbic acid to reverse multidrug resistance in cancer cells. Anticancer Res., 2012, 32: XXX, accepted.

IF:1.656

II. Parekh, S.; Bhavsar, D.; Savant, M.; Thakrar, S.; Bavishi, A.; Parmar, M.; Vala, H.; Radadiya, A.; Pandya, N.; Serly, J.; Molnár, J.; Shah, A. Synthesis of some novel benzofuran-2-yl(4,5-dihyro-3,5-substituted diphenylpyrazol-1-yl) methanones and studies on the antiproliferative effects and reversal of multidrug resistance of human MDR1-gene transfected mouse lymphoma cells in vitro. Eur. J. Med. Chem., 2011, 46: 1942-1948.

IF: 3.193

III. Ivanova, A.; Batovska, D.; Todorova, I.; Stamboliyska, B.; Serly, J.; Molnár, J. Comparative study on the MDR reversal effects of selected chalcones. Int. J. Med. Chem., 2011, DOI:10.1155/2011/5307800.

IV. Cindric, M.; Cipak, A.; Serly, J.; Plotniece, A.; Jaganjac, M.; Mrakovcic, L.; Lovakovic, T.; Dedic, A.; Soldo, I.; Duburs, G.; Zarkovic, N.; Molnár, J. Reversal of multidrug resistance in murine lymphoma cells by amphiphilic dihydropyridine antioxidant derivative. Anticancer Res., 2010, 30: 4063-4069.

IF: 1.656

V. Pusztai, R.; Abrantes, M.; Serly, J.; Duarte, N.; Molnár, J.; Ferreira, M.J.U. Anti-tumorpromoting activity of lignans: inhibition of human cytomegalovirus IE gene expression. Anticancer Res., 2010, 30: 451-454.

IF: 1.656

VI. Spengler, G.; Ramalhete, C.; Martins, M.; Martins, A.; Serly, J.; Viveiros, M.; Molnár, J.; Duarte, N.; Mulhovo, S; Ferreira, M.J.U.; Amaral, L. Evaluation of cucurbitane-type triterpenoids from Momordica balsamina on P-glycoprotein (ABCB1) by flow cytometry and real-time fluorometry. Anticancer Res., 2009, 29: 3989-3994. IF: 1.428 
VII. Das, S.; Das, U.; Selvakumar, P.; Sharma, R.K.; Balzarini, J.; De Clercq, E.; Molnár, J.; Serly, J.; Baráth, Z.; Schatte, G.; Bandy, B.; Gorecki, D.K.J.; Dimmock, J.R. 3,5Bis(benzylidene)-4-oxo-1-phosphonopiperidines and related diethyl esters: potent cytotoxins with multi-drug-resistance reverting properties. ChemMedChem, 2009, 4: 1831-1840.

IF: 3.232

VIII.Szolnoki, Z.; Serly, J.; Kondacs, A.; Mándi, Y.; Somogyvári, F. Evaluation of the genetic variants of kinesin motor protein in ischemic stroke. J. Stroke Cerebrovasc. Dis., 2009, 18: 360-362.

IX. Somogyvári, F.; Dóczi, I.; Serly J.; Ahmad, S.; Nagy, E. Rapid discrimination between Candida albicans and Candida dubliniensis by using real-time PCR. Diagn. Microbiol. Infect. Dis., 2007, 58: 367-369.

IF: 2.448

$\Sigma I F=15.269$

Cumulative IF: 21.381 


\section{ABBREVIATIONS}

A2780/cis human ovarian cancer cell line and its cisplatin-resistant subline

ABC transporter ATP-binding cassette transporter

ABCB1 ABC transporter B 1

AV annexin- $\mathrm{V}$

ATP adenosine triphosphate

ATP7A/B ATPase P-type copper transporter $\alpha$ and $\beta$

BAX BCL2-associated X

BCL2 B-cell CLL/lymphoma 2

BCRP breast cancer-related protein

bp base pair

conc. concentration

CI confidence interval

cisplatin cis-diamminedichloroplatinum(II)

CTR copper transporter (also called as SLC31)

DNA deoxyribonucleic acid

DMSO dimethyl sulfoxide

EDTA ethylenediaminetetraacetic acid

FACS fluorescence-activated cell sorter

FAR fluorescence activity ratio

FIC fractional inhibitory concentration

FITC fluorescein isothiocyanate

FIX fractional inhibitory index

HRP horseradish peroxidase

HWE Hardy-Weinberg equilibrium

$\mathbf{I C}_{\mathbf{5 0}}$ calculated concentration of the compound for $50 \%$ inhibition of cell growth in vitro

KSH Központi Statisztikai Hivatal (Hungarian Central Statistical Office)

LDA linkage disequilibrium analysis

M627 12H-benzo(a)phenothiazine

MAB(s) monoclonal antibody(ies)
MDR multidrug resistance or a human ABCB1 gene-transfected mouse lymphoma subline of PAR

MRP multidrug resistance-related protein

MTT 3-(4,5-dimethyiltiazol-2-yl)-2,5diphenyltetrazolium bromide

NBD nucleotide binding domain

nt. nucleotide

NTP nucleoside triphosphate

OR odds ratio

P53 tumor protein 53

P. nigelastrum Peganum nigelastrum

PAR parental human mouse lymphoma cell line PBS phosphate-buffered saline

PCR polymerase chain reaction

PI propidium iodide

PS power and sample size

$\mathbf{R E}$ restriction endonuclease

RFLP restriction fragment length polymorphism

RPMI Roswell Park Memorial Institute

rs reference sequence

S. excelsa Smilax excelsa

SDS sodium dodecyl sulphate

SLC31 solute carrier family (also called as CTR)

SNP(s) single nucleotide polymorphism(s)

T. terrestris Tribulus terrestris

Taq polymerase Thermus aquaticus polymerase

TBS Tris-buffered saline

TMD transmembrane domain

V. Iobelianum Veratrum lobelianum

V. nigrum Veratrum nigrum

WHO World Health Organization 


\section{LIST OF FIGURES}

page

Figure 1. $\mathrm{ABC}$ transporters responsible for cancer drug resistance.

Figure 2. Schematic representation of the primary structure of ABCB1 embedded in the plasma membrane.

Figure 3. Structure of the ABCB1 transporter with nucleotide binding domain (NBD) closed dimer and transmembrane domains (TMDs).

Figure 4. Schematic representation of copper homeostasis.

Figure 5. Proposed topology of the human CTR1 transporter.

Figure 6. Proposed topology of the ATP7A and ATP7B P-type transporters.

Figure 7. Structure of cisplatin.

Figure 8. ABCB1 staining of ovarian cancer (A2780cis) (left) and human ABCB1transfected mouse T-cell lymphoma (MDR) (right) cells by PGLYm monoclonal antibody (MAB).

Figure 9. MRP1 apecific red staining of the cytoplasm of ovarian cancer (A2780cis) (left) and human ABCB1-transfected mouse T-cell lymphoma (MDR) (right) cells by NCL-MRP1 monoclonal antibody (MAB).

Figure 10. Apoptosis induction in A2780cis ovarian cancer cells.

Figure 11. Structure of the most active five semisubstituted steroid-type compounds $(2,5,6,12$ and 25$)$. 


\section{LIST OF TABLES}

page

Table I. Cancer-related single nucleotide polymorphisms selected for SNP studies examined by PCR-RFLP.

Table II. The effects of semisubstituted steroids (1-35) on cell proliferation $\left(\mathrm{IC}_{50}\right)$ 26 and drug resistance (FAR) in ovarian cancer (A2780cis) and mouse Tcell lymhoma (MDR) cells.

Table III. The effects of selected steroid derivatives $(4,5,25)$ and their complexes with platinum(IV)-chloride and copper(II)-perchlorate (4C, 5C, 25C and 4P, 5P, 25P) on cell proliferation $\left(\mathrm{IC}_{50}\right)$, drug resistance $(\mathrm{FAR})$ and their interaction with anticancer drugs (FIX) in A2780cis and MDR cells.

Table IV. The effects of hydantoin derivatives on cell proliferation $\left(\mathrm{IC}_{50}\right)$ and drug resistance (FAR) in MDR cells.

Table V. The effects of alkaloids (A1-9) on cell proliferation $\left(\mathrm{IC}_{50}\right)$ and drug resistance (FAR) in MDR cells.

Table VI. Interaction between selected hydantoin derivatives and doxorubicin in MDR cells.

Table VII. Effects of selected semisubstituted steroids and their copper or platinum complexes on apoptosis induction in A2780cis cells.

Table VIII. Effects of selected semisubstituted steroids and their copper or platinum complexes on apoptosis induction in MDR cells.

Table IX. Results of the PCR-RFLP experiments in which five SNPs of four cancer-related genes $(A B C B 1, B A X, B C L 2, P 53)$ were examined. 


\section{INTRODUCTION}

\section{Present state of the cancer burden}

Death from cancer represents around one eighth of all deaths in the world. In the past 30 years, the yearly detected new cases of cancer patients has been doubled, in 2008 approximately 12.7 million new patients were diagnosed with cancer, and an estimated 7.6 million people died of cancer in the world (1). In the WHO (World Health Organization) European Region 3.4 million people were diagnosed with and 1.8 million people died of cancer. This represents more than $23 \%$ of the people who died from cancer all over the world; however, the population of this region represents less than $15 \%$ of the world's population. The higher ratio is the consequence of the aging population with a bulge-number of middle age and decreasing number of births in the younger age categories (1).

In Hungary the problem of the aging population is even more serious; the population has been decreasing by $0.3 \%$ yearly for 10 years. Now there are fewer than 10 million Hungarians. The most affected first baby-boom generation of Ratkó-era born in the mid $20^{\text {th }}$ century is at the end of their middle-age, and their children have just reached middle-age, so the ratio of cancer cases is even higher than expected.

The mortality in Hungary has been significantly elevated for a long time, but in the last 20 years the overall number of death cases has significantly decreased from the 145.660 deaths of the early nineties to the 130.456 deaths detected in 2010 according to the data of the Hungarian Central Statistical Office (Központi Statisztikai Hivatal, KSH) (2).

The number of cancer patients has been considerably increased in the $20^{\text {th }}$ century due to the aging and civilization harms, but it has been more or less stabilized in the last 20 years at around 70.000. At present, there are about 300.000 cancer patients and 32.460 people died of malignant neoplastic diseases in Hungary in 2010. Cancer is the second most frequent cause of death following cardiovascular diseases with 47.743 deaths in 2010 in Hungary according to the KSH data (2). The risk of getting cancer is $28.1 \%$, and the risk of dying from cancer is $17.6 \%$ under the age of 75 in Hungary which values are significantly higher in comparison with the value calculated for the EURO region: $24 \%$ and $12.5 \%$ and for the world: $18.7 \%$ and $11.2 \%$, respectively (3). (The risk of getting/dying of cancer means the 
probability or risk of individuals getting/dying from cancer expressed as the number of new born children (out of 100) who would be expected to develop/die from cancer before the age of 75 if they had cancer - in the absence of other causes of death). In Hungary, the leading cancer types according to cancer incidence are breast, lung, colorectal, prostate cervix uteri, corpus uteri, bladder and ovary, but there are differences in incidence between sexes. Among women, the range of cancer incidence is breast, colorectal, lung, cervix uteri, corpus uteri, ovary, pancreas, stomach and melanoma of the skin (3). Ovarian cancer is the sixth most frequent cancer type in Hungary among women with its incidence of. $4.3 \%$ and mortality of. $5 \%$ within cancer types (3).

Due to the aging of the Hungarian population predicted for the next decades, cancer incidence will dramatically raise, therefore, scientific discovery into new approaches to cancer treatment and therapy prediction is even more urgent.

A complete understanding of the mechanisms of the development of cancer is very unlikely to come about in the foreseeable future, making impossible reliance on a single approach to prevent cancer and deaths from the disease. Pharmacological research is of paramount importance from basic research to clinical phase studies. The development of new anticancer drugs cannot only improve the efficacy of treatment, but it can reduce the side effects. In cancer research, genetic aspects have become even more important for revealing the molecular basis of the disease that can have a predictive value in cancer development and can contribute to forecast the efficacy of treatment.

\section{Cancer treatment}

The term cancer including a class of diseases is characterized by uncontrolled and invasive growth of cells. These cells may spread to other parts of the body, and this is called metastasis. The biological properties of malignant tumor cells summarized by Hanahan and Weinberg are as follows: 1. acquisition of self-sufficiency in growth signals, leading to unchecked growth; 2 . loss of sensitivity to anti-growth signals, also leading to unchecked growth; 3. loss of capacity for apoptosis, in order to allow growth despite genetic errors and external anti-growth signals; 4 . loss of capacity for senescence, leading to limitless replicative potential (immortality); 5. acquisition of sustained angiogenesis, allowing the tumor to grow beyond the limitations of passive nutrient diffusion; 6. acquisition of ability to invade neighboring tissues, the defining property of invasive carcinoma; 7. acquisition of ability to 
build metastases at distant sites, the classical property of malignant tumors (carcinomas or others), and; 8. loss of capacity to repair genetic errors, leading to an increased mutation rate (genomic instability), thus, accelerating all of the other changes (4). These changes occurring at genetic or epigenetic level can lead even to increased resistance to anticancer treatment.

Treatment throughout history has ranged from removal of organs to targeting specific markers on cancer cells with molecular drugs. Nowadays, the hallmark of cancer treatment is even more diverse, ranging from the general therapies, e.g. irradiation, surgery and standard chemotherapy to the more sophisticated therapies, e.g. immunobiological therapy. Other personalized therapies are under development, such as anticancer vaccination and viral gene therapy of cancer by adenovirus particles (5).

Our research focuses on the adjuvant therapy of cancer that can help to reduce the resistance occurring before or during the treatment following standard recommendations of chemotherapy. The level of resistance can be modified by special membrane transporters, for instance, ABC (ATP-binding cassette) or copper transporters (6-8). Moreover, other additional advantages can be outlined with the development of adjuvant agents, such as reducing the level of neutropenia and cachexia $(9,10)$.

\section{Drug resistance of cancer cells}

Cancer resistance to drugs is of paramount importance when evaluating the response to chemotherapy; therefore, its relevance is unambiguous in clinical practice (11). Treatment failure can be due to pharmacokinetic mechanisms, also called pharmacokinetic resistance; the consequence is decreased drug exposure of cancer cells (12).

There are two ways by which clinical tumor resistance takes place: intrinsic and acquired resistance. Intrinsic resistance is present at the time of diagnosis in tumors that fail to respond to first-line chemotherapy. Acquired resistance occurs in tumors that are often highly responsive to initial treatment, but on tumor recurrence, exhibit an entirely different phenotype. They become resistant to the previously used drug and to new agents with different structures and mechanisms of action $(7,13)$.

Multidrug resistance (MDR) is the main reason for the reduced effect of chemotherapy in many cancer types. Experimentally, tumor cells in vitro exposed to one cytotoxic agent develop cross-resistance to a range of structurally and functionally unrelated compounds (14). A number of different mechanisms $(15,16)$ can mediate the development of MDR in cancer 
including increased drug efflux from the cells (17-19), decreased drug uptake into the cells $(20,21)$, alteration of drug targets $(22,23)$, increased DNA repair mechanisms $(24,25)$ and defective apoptotic pathways $(26,27)$.

It is very common for cancer cells to be resistant to chemotherapeutic agents that is due to a multifactorial mechanism. However, overexpression of the ABC (ATP-binding cassette)transporters (e.g. MDR1: multidrug resistance protein 1, ABCB1; MRP1: multidrugresistance-related protein 1, $\mathrm{ABCC} 1$; $\mathrm{BCRP}$ : breast cancer resistance protein, $\mathrm{ABGC} 2$ ) is amongst the most important reasons (28-30).

Besides ABCB1-mediated resistance, the main focus of the research was to overcome cisplatin resistance of a cisplatin-resistant ovarian cancer cell line (A2780cis). Previously, it has been shown that cancer cells can develop cisplatin resistance through: 1. changes in drug transport leading to reduced intracellular cisplatin accumulation due to copper transporters; 2 . an enhanced drug detoxification system due to elevated levels of intracellular scavengers, such as glutathione and/or metallothioneins; 3. changes in DNA repair involving increased nucleotide excision repair; 4. interstrand crosslink repair or loss of mismatch repair; 5. changes in DNA damage tolerance mechanisms, and; 6. changes in the apoptotic cell death pathways (31).

In ovarian cancer, up to two-thirds of tumor specimens have been found to overexpress $\mathrm{ABCB} 1$ and this overexpression has been shown in some cases to correlate with poor overall survival $(13,32,33)$. However, in case of the A2780cis cell line, ABCB1 overexpression does not seem to be important in cisplatin resistance (34). Other gene families responsible for cisplatin resistant ovarian cancer are the families of copper transporters (CTRs or SLC31) and P-type transporters, whose members are localized in the plasma membrane, such as CTR1, or localized in the intracellular membranes, such as the other member of the SLC31 transporters called CTR2 or P-type copper transporter $\alpha$ and $\beta$ (ATP7A/B) $(19,35)$.

We also focused on the genetic aspect of cancer, since drug resistance of cancer may also be due to alterations in gene expression, forasmuch changes in certain regulatory genes can lead to increased or decreased expression levels of proteins important in resistance and survival of cancer cells. The direct effect is the altered physiological function of membrane transporters i.e. higher efflux (ABCB1) or lower influx rate (CTR1). The indirect effect is due to structural changes in other proteins, for instance, in the apoptosis pathway (P53, BAX, and 
BCL2). The most common genetic cause of resistance is the alteration in certain loci, called single nucleotide polymorphisms (SNPs) $(36,37)$, when a base change leads to different protein structure or can result in a different binding site upstream or downstream from the coding region that inhibits or strengthens the binding of proteins important in signal transduction pathways (38). Therefore, it results in different expression levels of certain proteins responsible for resistance directly or indirectly. Although the research of SNPs in correlation with cancer treatment outcome has been intensified recently, the data still conflict, hence, the necessity for SNP studies pursues further investigation.

\subsection{ABC transporters}

The ability of $\mathrm{ABC}$ transporters to efflux diverse drugs prior to reach their intended targets provided an explanation for the clinical phenomenon of MDR. The superfamily of ABC transporters, comprised of 48 members, includes seven families designated A through G (39). ABC transporters couple the hydrolysis of adenosine triphosphate (ATP) to move drugs and xenobiotics unidirectional out of cells, thereby promoting drug resistance (Figure 1) (40). ABC transporters are membrane

proteins consisting of both transmembrane domains (TMDs) and distinctive nucleotide binding domains (NBDs) which generate

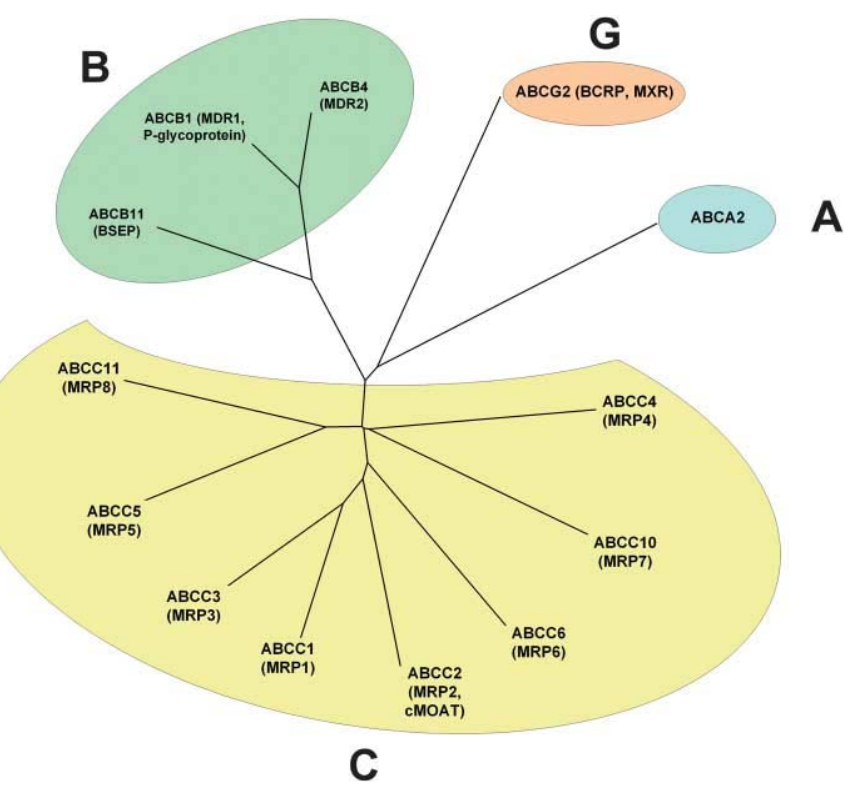

Figure 1. $\mathrm{ABC}$ transporters responsible for cancer drug resistance. (Figure taken from Ross, D.D.; Doyle, L.A. Cancer Cell, 2004, 6, 105-107 (40).) energy from ATP hydrolysis to actively transport a variety of compounds across the plasma membrane. These subfamilies (ABCA-ABCG) are based on sequence homology and domain organization. While the roles of $13 \mathrm{ABC}$ transporters in MDR have been fully characterized, recent studies suggest the involvement of more than 20 members out of the 48 encoded in the human genome (41). Nowadays, three members of the ABC transporters have been the most extensively studied: 
$\mathrm{ABCB} 1, \mathrm{ABCC} 1$ and $\mathrm{ABCG} 2$ (42). In our investigation we focused on MDR reversal of an MDR mouse T-cell lymphoma cell line transfected with the human gene that encodes the $\mathrm{ABCB} 1$ transporter. The expression of human $\mathrm{ABCB} 1$ in this cell line is much higher in comparison with normal cells of human which makes it to be a good model cell line to examine the $\mathrm{ABCB} 1$-related drug resistance.

Essentially, when these $\mathrm{ABC}$ drug transporters are overexpressed in cancer cells, they can confer cross-resistance to multiple drugs of differing chemical classes by actively extruding cytotoxic drugs, thus, they reduces the accumulated amount of drug below the effective chemotherapeutic level and result in MDR (16). In addition, at least 15 genetic disease conditions have been associated with defects in 20 members of the $A B C$ superfamily, such as cystic fibrosis (ABCC7), Tangier-disease (ABCA1), Dubin-Johnson syndrome $(\mathrm{ABCC} 2)$ and pseudoxanthoma elasticum (ABCC6) (43).

\section{Structure and function of $A B C B 1$}

The ABCB1 gene is located on chromosome 7 in humans and encodes 1280 amino acids (44). It functions as an ATP-driven efflux transporter and moves its substrates from intracellular to extracellular direction. It has 12 transmembrane sequences, of which the number 5, 6, 11 and 12 sequences seem to be responsible for the transport function (Figure 2, page 7) $(45,46)$.

A functional unit of an $\mathrm{ABCB} 1$ transporter requires two nucleotide binding domain regions (NBDs), and two transmembrane domain regions (TMDs). Furthermore, the units are composed of several conserved sequence motifs, the A-loop (an aromatic residue 25 amino acids upstream of the Walker A), the Walker A, the Walker B, the signature motif (LSGGQ motif, linker peptide or $\mathrm{C}$ motif) and the $\mathrm{D}, \mathrm{H}$ and Q-loops. Crystal structures of the $\mathrm{ABC}$ domains of several $\mathrm{ABC}$ transporters indicate that a functional ATP site is formed by the interaction of residues from both halves of the protein (47-50). 


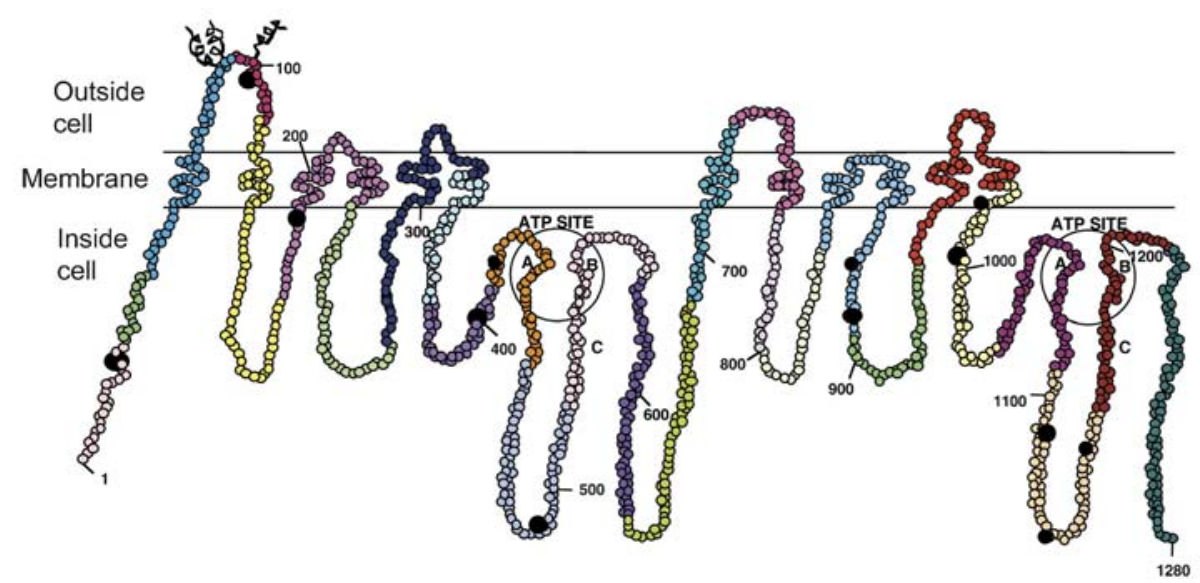

Figure 2. Schematic representation of the primary structure of ABCB1 embedded in the plasma membrane. The molecule contains 1280 amino acids spanning 28 exons (each exon sequence is presented in different color). Black dots show the location of some of the identified SNPs. (Figure taken from Aszalos, A. Drug. Discov. Today, 2007, 12, 833-837 (46).)

There are several theoretical models for the action of the ABCB1 membrane transporter, but the most possible way of function is described by the ATP switch model (51). This model involves repeated communication, in both directions, between the NBDs and TMDs (Figure 3).

Figure 3. Structure of the ABCB1 transporter with nucleotide binding domain (NBD) closed dimer and transmembrane domains (TMDs). As no complete transporter with bound ATP has been crystallized, a consensus structure based on structures of several NBDs and TMDs modeled for ABCB1 is shown. The two ATP molecules and two magnesium ions, shown in ball-and-stick and colored by atom types, occupy the two nucleotide binding pockets at the interface

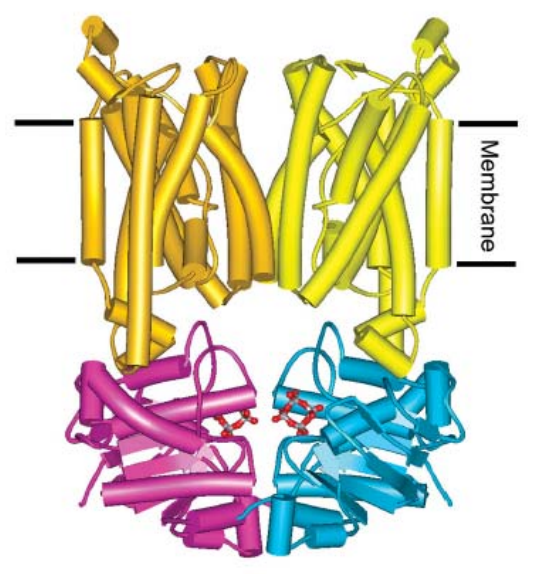
between the two NBDs and are coordinated by residues from both NBD regions. (Figure taken from Higgins, C.F.; Linton, K.J. Nat. Struct. Mol. Biol., 2004, 11, 918-926 (51).)

Unlike in case of P-type transporter ATPases (ATP7A/B), there are no phosphorylated protein intermediates, and communication involves only noncovalent conformational changes. At the heart of the model is a switch between two principal conformations of the NBDs: formation of a closed dimer upon binding two ATP molecules at the dimer interface; and dissociation to an open dimer facilitated by ATP hydrolysis and release of $\mathrm{P}_{\mathrm{i}}$ and ADP (adenosine diphosphate). 
The kinetics of this switch are enhanced by cooperativity between the two nucleotide binding pockets, and can be tightly regulated by signals from the TMDs. Switching between the open and closed configurations of the dimer induces conformational changes in the TMDs necessary for vectorial transport of substrate across the membrane (51).

$\mathrm{ABCB} 1$ is expressed in the apical membrane of many secretory cell types, such as kidney, liver, intestine, adrenal gland, and the blood-brain barrier, where the normal function involves the excretion of drugs and their metabolites $(52,53)$. Thus, suggesting a barrier function to inhibit the entering of toxic materials into such vulnerable organs (30). Furthermore, high-level expression of $\mathrm{ABCB} 1$ can be observed in hormone-producing tissues, such as pancreatic ductules and steroid-producing endometrial glands, indicating its role in steroid hormone transport e.g. aldosterone and corticosterone (30).

The expression level is variable in different tissues, and can be activated by substrates via feed-back mechanisms (54). In cancer cells the increased ABCB1 expression comes off de novo as a result of genetic or epigenetic changes, or can be the consequence of chemotherapeutic treatment, which is called secondary resistance that can be caused by epigenetic changes, too. De novo and secondary types of resistance are very common in cancer, for instance, they are presented in $65 \%$ and $80 \%$ in acute myeloid leukemia and $15 \%$ and $47 \%$ in ovarian cancer, respectively (29).

\section{Substrates and modulation of ABCB1}

The substrates of ABCB1 are mostly hydrophobic and amphipathic compounds that are transported actively out of the cells by an ATP-dependent mechanism (16). It has been revealed that most substrates of the ABCB1 possess two or three electron donor groups with a fixed spatial separation of 2.5 and $4.6 \AA$, with an increased number of these elements increasing the affinity to drug binding (55). Correspondingly, there is a high percentage of amino acids with hydrogen bonding donor side chains in the transmembrane sequences of ABCB1 responsible for substrate recognition. Further studies have found that partitioning into the lipid membrane is the rate-limiting step for the interaction of a substrate with ABCB1 and that dissociation of the ABCB1-substrate complex is determined by the number and strength of the hydrogen bonds formed between the substrate and ABCB1 membrane transporter (56). 
Most ABCB1 inhibitors share some common chemical features, such as aromatic ring structures, a tertiary or secondary amino group and high lipophylicity, although ABCB1 substrates as a whole have varying classes of inhibitory action (57).

In cancer treatment, the potential therapeutic use of ABCB1 inhibitors is very important, because the co-administration with existing chemotherapy drugs will help to negate cancer multidrug resistance caused by ABCB1 (52). Due to the nature of ABCB1 as an efflux pump for cell protection against a variety of structurally unrelated substances, its substrates vary greatly in size, structure and function, ranging from small molecules, such as organic cations, carbohydrates, amino acids, and some antibiotics to macromolecules, such as polysaccharides and proteins $(16,58)$. The most common inhibitor is verapamil which is generally used as positive control in the MDR reversal rhodamine 123 (R123) excluding FACS experiments (59). Moreover, this pump can be not only induced by chemical compounds, but also by physical stress, such as X-irradiation, ultraviolet light irradiation, and heat shock (55).

Several compounds have been found as promising MDR modifiers e.g. flavonoids and phenothiazines such as chlorpromazines, stilbenes, di- and triterpenes and carotenoids at the Department of Medical Microbiology and Immunobiology in the last 30 years (60-65). Furthermore, specifically modified compounds such as metal coordination complexes of tricyclic compounds have also been investigated, since it has been assumed that metals induce some changes in binding features to ABCB1 (61).

\subsection{Copper transporters in cisplatin resistance}

The platinum drugs like cisplatin, carboplatin and oxaliplatin enter cells much more slowly than most other classes of small-molecule anticancer agents. Current evidence suggests that one component of their uptake is mediated by copper transporter 1 and 2 (CTR1 and CTR2) (66). Furthermore, besides the overexpression of ABCB1, CTR1 is the most commonly identified protein in cancer that leads to drug resistance (66-69). Decreased drug accumulation may be partly the result of the upregulation of this CTR1 copper transporter, whose mechanism is common in certain tumors, such as of the human ovarian, testicle, lung or head and neck cancers (70).

A number of studies have demonstrated that besides CTRs, the ATPase copper efflux transporter $\alpha$ and $\beta$ (ATP7AB) modulate the export of cisplatin (Figure 4, page 10) (71-74). These copper transporters are of distinct origin. 
The CTR (also called SLC31) family belongs to the solute carrier (SLC) superfamily that currently includes 50 families (SLC150) and almost 400 genes according to the Human Genome Organisation (HUGO) Nomenclature Committee Database (75). The SLC series includes genes encoding passive transporters, ion coupled transporters and exchangers (76). One of the two CTR transporters representing the SLC31 family is called CTR1 (SLC31A1) that was

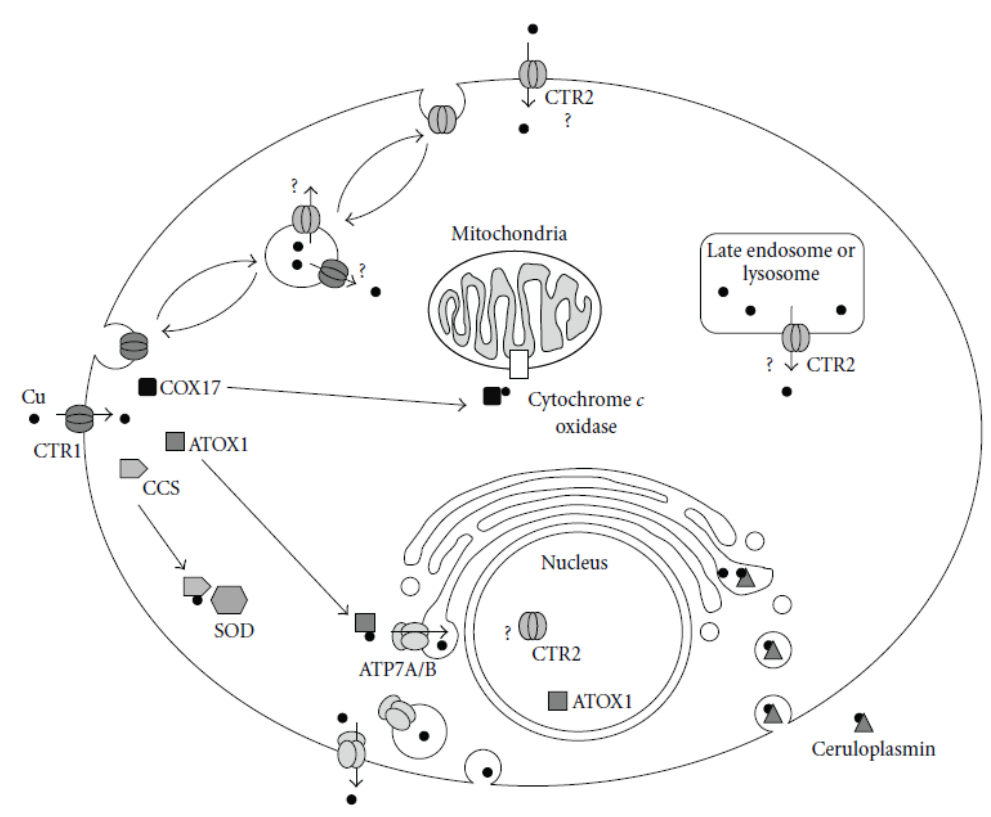

Figure 4. Schematic representation of copper homeostasis. While CTR1 rather participates in copper influx, CTR2 seems to be working in both direction depending on the stimuli, however, its function is less well defined. P-type transporters (ATP7A/B) are most likely participated in the intracellular vesicular copper transport. (Figure taken from Abada, P.; Howell, S.B. Met. Based Drugs., 2010, 2010: 317581 (74).) described as the major copper influx transporter that controls the uptake of platinum-containing drugs. According to recent studies, it has been shown that mammalian cells express a second structurally related transporter, the other member of SLC31 family, the CTR2 (SLC31A2), whose function is less well-defined. Although CTR1 functions to influx both copper and cisplatin into the cell, a recent study demonstrated that CTR2 has the opposite effect and serves to limit the accumulation of cisplatin in cell line models (77). Blair et al. also reported that CTR2 mRNA and protein levels increased when mammalian cells were exposed to either copper or cisplatin. They demonstrated that CTR2 protein was rapidly degraded when cells were starved for copper. Similar to the effect of knocking down CTR2 expression using short hairpin RNA interference, the loss of CTR2 caused by depletion of cellular copper led to increased cisplatin accumulation and cytotoxicity. Furthermore, they also reported that CTR2 was found not only 
in intracellular membranes but also in the nucleus and that exposure to either copper or cisplatin increased the level of CTR2 in the nucleus as well as in the cytoplasm (78).

ATPases (copper-transporting Cu-ATPases) represent a large superfamily of P-type membrane transporters consisting of ATP1-13 families with approximately 140 members (75). The Cu-ATP-ase family of transporters uses the energy of ATP hydrolysis to transport copper across cell membranes. The most studied Cu-ATPases in human are ATP7A and ATP7B. It is thought that the Cu-ATPases perform at least three major functions: 1. mediate copper uptake; 2. prevent toxic copper accumulation; and, 3. in eukaryotic cells participate in the biosynthesis of copper-dependent enzymes in the secretory pathway, therefore, preventing diseases, such as Menkes and Wilson-disease (79-81).

ATP7A is expressed in the intestinal epithelium as well as most other tissues other than liver, and the pathology of X-linked Menkes disease reflects inadequate mobilization of copper from a number of tissues such as intestine, kidney and blood-brain barrier (82-85). ATP7B is expressed in liver and kidney and to a lesser extent in brain of normal individuals, consistent with excessive copper accumulation observed in these tissues when ATP7B function is lost in patients with the autosomal recessive Wilson's disease (86). ATP7A and ATP7B are found predominantly in the membranes of the trans-Golgi network and endocytic vesicles, and to a lesser extent at the plasma membrane. ATP7A and ATP7B cycle between these compartments in response to changing copper levels, as well as other stimuli. This regulated intracellular localization determines whether copper is utilized for the biosynthesis of copper-dependent enzymes in the secretory pathway, sequestered in vesicles for storage, or rapidly released from vesicles into the extracellular milieu for export and, possibly, signaling (87).

\section{Structure and function of CTR1/2 and ATP7A/B}

The main copper uptake transporter in human cells is CTR1 whose gene is localized on chromosome 9; it encodes a 190 amino acid protein with three transmembrane domains. CTR1 can form oligomeric (most likely homotrimer) complexes, possibly to facilitate pore formation for copper uptake $(88,89)$. The methionine- and histidine-rich amino terminal of CTR1 may be important in copper binding (Figure 5, page 12) (90). 


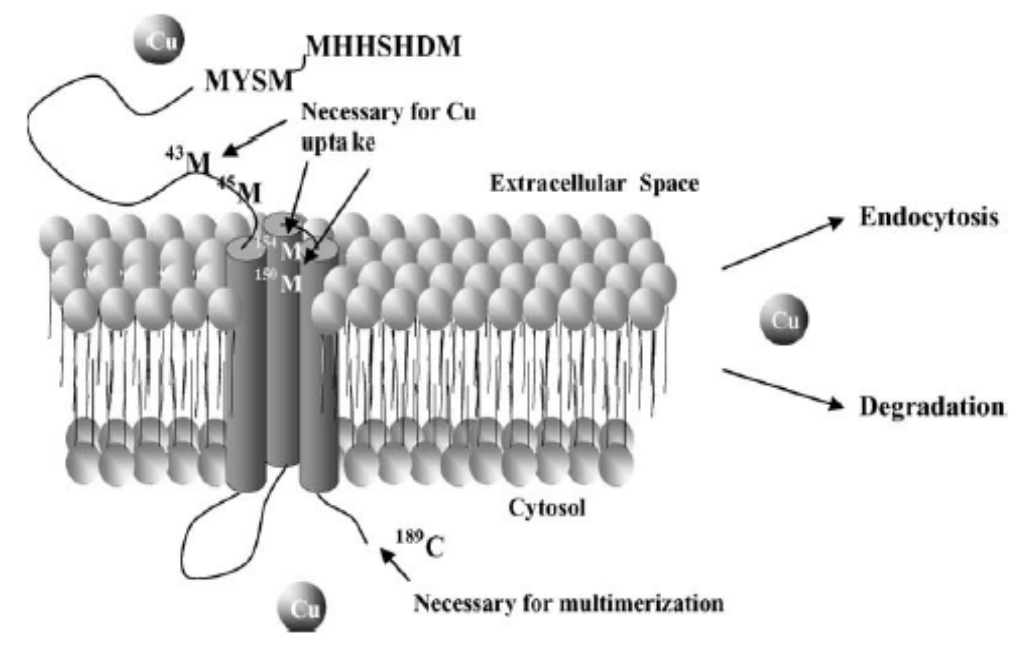

Figure 5. Proposed topology of the human CTR1 transporter. The methionine residues $(\mathrm{M})$ at the extracellular amino-terminal domain are required for $\mathrm{Cu}$ binding. (Figure taken from Safaei, R.; Howell, S.B. Crit. Rev. Oncol. Hematol., 2005, 53: 13-23 (90).)

The other SLC31 family member copper transporter CTR2 is localized in chromosome 9 as well, and encodes a 143 amino acid protein. Less is known about the function and structure of CTR2; however, CTR2 functions as a homomultimer similar to CTR1. In contrast to CTR1, lower levels of CTR2 increase the cellular uptake of platinum-based chemotherapeutic drugs and toxicity to the drugs $(77,91)$. Knocking down CTR2 in mouse embryonic fibroblast cells increased the accumulation of cisplatin by 2-3-fold, which was associated with increased cytotoxicity to cisplatin. Furthermore, an investigation of several human ovarian carcinoma cell lines revealed that CTR2 content was inversely correlated with sensitivity to cisplatin (77). CTR2 is predominantly localized in endosomes and lysosomes in mammalian cells; however, when expressed at the cell surface, CTR2 is capable of mediating copper uptake as well (91-93).

Export of copper from mammalian cells besides CTR2 involves two P-type ATPases, ATP7A and ATP7B. The two copper efflux proteins are homologous both in structure $(54 \%$ amino acid similarity) and in function. ATP7A is localized in chromosome $\mathrm{X}$, but ATP7B is localized in chromosome 13. Both ATP7A and ATP7B are 160-170 kDa membrane proteins with eight transmembrane segments and several cytosolic domains, ATP7A is glycosylated (presumably in the first luminal loop), while B is not. The sixth transmembrane domain is conserved and forms the channel through which copper moves. Both proteins also have 6 'metal binding sequences' (MBS) repeats of approximately 70 amino acids each at the Nterminal cytosolic side. ATP7B and ATP7A are P1-(CPx)-type ATPases, and like other Ptype ATPases, function as monomers and couple the energy of ATP hydrolysis with the uphill transport of cations across cell membranes (Figure 6, page 13) (90). ATP7A is likely to have 
a faster turnover compared with ATP7B because it performs key steps of the catalytic cycle faster than ATP7B; however ATP7B may have a higher affinity for copper (94).

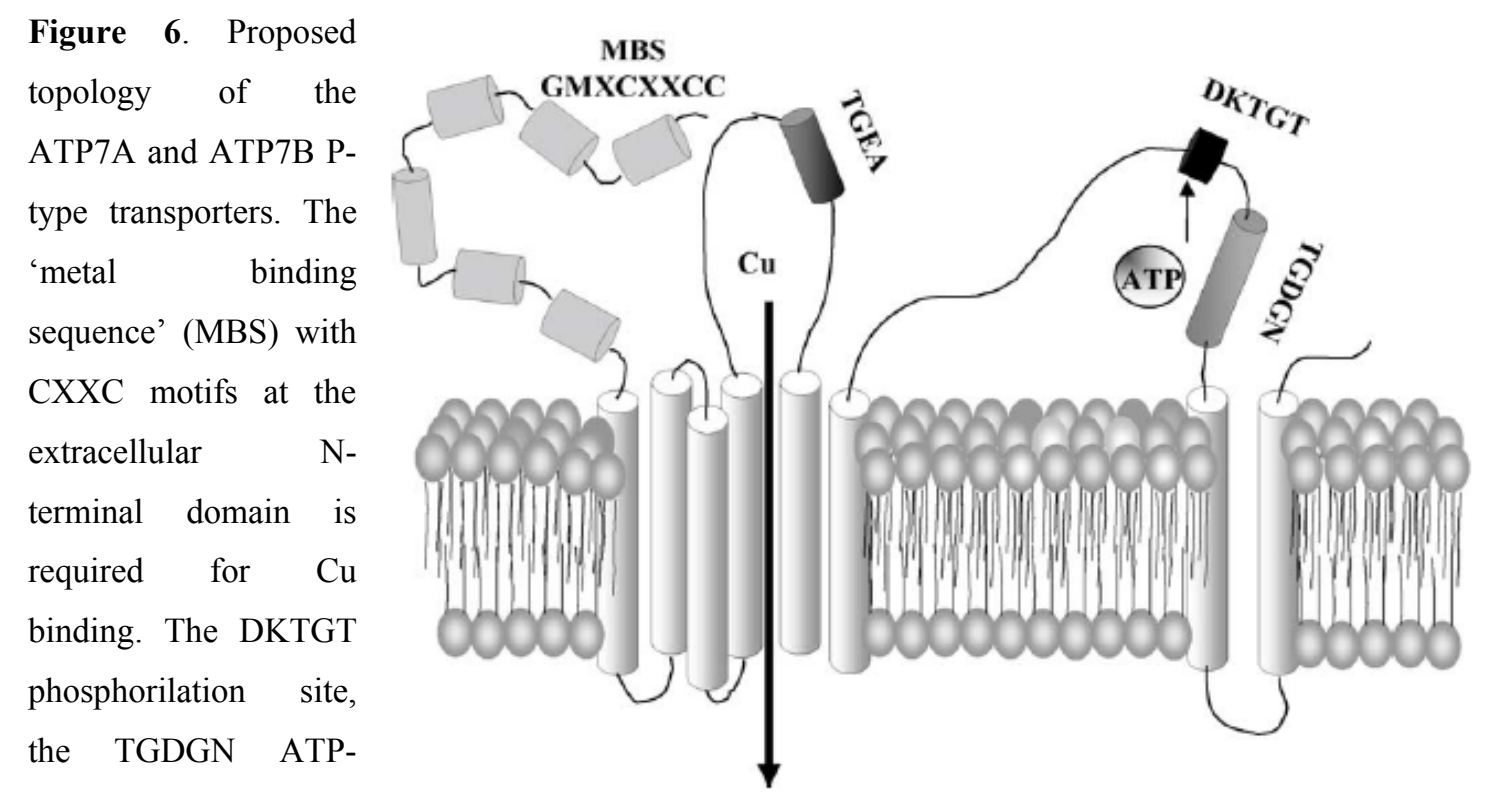

binding site, and the

TGEA phosphatase domain are conserved in all of the P-type ATPases. (Figure taken from Safaei, R.; Howell, S.B. Crit. Rev. Oncol. Hematol., 2005, 53: 13-23 (90).)

\section{Substrates and modulation of CTR1/2 and ATP7A/B}

The CTR1 and CTR2 copper transporter mediates the transport of cisplatin and, therefore, essential in cisplatin resistance $(90,94,95)$. Furthermore, cross resistance of cisplatin and other platinum-based drugs like carboplatin and oxaliplatin has been proved as well (96). However, the mechanism by which these drugs enter the cell is still not completely clear. It has also been reported that CTR1 mediates other ion influx like selenium, vanadium, zinc or iron (97).

The overexpression of ATP7A and B has been observed in cisplatin resistant cell lines, for example, in prostate carcinoma, epidermoid carcinoma and ovarian tumors, however, the mechanism of efflux is still unclear (98).

All of these copper transporter proteins contain metal binding motifs which, in addition to binding copper ion, are likely to interact with the platinum-based drugs as evidenced by the results of crystallographic and mass spectrometry experiments $(71,98,99)$.

Since CTR1 is responsible for the influx of platinum-based drugs, upregulation would be necessary to increase the drug uptake; unfortunately, direct upregulation of the CTR1 
transporter seems to be much more complicated in comparison with the inhibition of $\mathrm{ABC}$ transporters. Because of the nature of CTR2 and these ATP7A/B transporters responsible for the efflux of platinum-based drugs, from this point of view, CTR2, ATP7A and B are similar to $\mathrm{ABC}$ transporters. Conversely, CTR2 and P-type transporters can be localized in the membrane of intracellular vesicles trafficking drugs out of the cell, therefore, targeting these proteins intracellular environment is more complicated. It has already been demonstrated that a clusterin, a chaperon-like protein, participates in the degradation of Cu-ATPases (100). In conclusion, modulating these copper transporters directly seems to be complicated, but not impossible; therefore, we tried to overcome cisplatin resistance directly.

\section{Association between SNPs and diseases of genetic origin}

Genetic variation in the human genome is an emerging resource for studying cancer. The most common sequence variation in the human genome is the stable substitution of a single base, the single nucleotide polymorphism (SNP). By definition, a SNP has a minor allele frequency of greater than $1 \%$ in at least one population, whereas mutations are rare and occur in less than $1 \%$ of the population (usually much less than 1\%). SNPs are present throughout the human genome with an average frequency of approximately 1 per 1.000 base pairs (bp) (101). 'The SNP Consortium' (a consortium of pharmaceutical and bioinformatics companies, five academic centers and a charitable trust, also denoted as International HapMap Project) is currently producing an ordered high-density SNP map of the human genome available at www.hapmap.org (102). Furthermore, other databases are available in SNP research, such as SNP500 Cancer of the National Institute of Health (NIH) Cancer Genome Anatomy Project, to find known or newly discovered single nucleotide polymorphisms (SNPs) which are of immediate importance in molecular epidemiology studies of cancer (103).

According to a report, approximately $50 \%$ of SNPs are found in noncoding regions, $25 \%$ lead to missense mutations, and the remaining $25 \%$ are silent mutations in the coding regions (104). Both synonymous and nonsynonymous SNPs can influence promoter activity and pre-mRNA conformation or stability. SNPs can also alter the ability of a protein to bind its substrates or inhibitors and change the subcellular localization of proteins (105). Therefore, these small genetic changes may be responsible for medicinal drug deposition and disease susceptibility, which have already been verified in certain diseases, such as age-related cortical cataract, diabetes mellitus and cancer (106-108). 


\section{Background of the thesis: from cancer drug resistance to single nucleotide polymorphisms}

The majority of cancer patients die as a consequence of 'ineffective' therapy including chemotherapy mediated drug resistance. To overcome MDR induced by the expression of human $\mathrm{ABCB} 1$, various compounds of synthetic and natural origin have been studied at the Department of Medical Microbiology and Immunobiology for more than 30 years in different cancer cell lines (lymphoma, lung, colon, breast, etc.). Several compounds have been found as promising resistance modifiers, for example, flavonoids and phenothiazines such as chlorpromazines, stilbenes, di- and triterpenes and carotenoids (60-65). Furthermore, specifically modified compounds have also been investigated, such as metal coordination complexes of tricyclic compounds, since it has been assumed that metals induce some changes in binding features to $\mathrm{ABCB} 1(61,109)$. (By definition, coordination complexes are compounds in which atoms, molecules or ions (ligands) are connected to metal atoms by dative bonds, thus both electrons of the bond derive from the ion or Lewis base (110).)

Metal complexes remain an important resource in the search for novel therapeutic and diagnostic agents, especially in the area of anticancer drug development (111). Moreover, the anticancer agent cisplatin $\left(\mathrm{PtCl}_{2}\left(\mathrm{NH}_{3}\right)_{2}\right.$, cis-diamminedichloroplatinum(II)) is a coordination complex itself (Figure 7.).

The target of the classical platinum-based drugs is DNA, leading to extensive DNA damage and cytotoxicity, which severely limits its usage (112). At present, a number of metal-based compounds are known to have promising antiproliferative effects in a wide range of tumors with novel modes of DNA binding, such as ruthenium(II) organometallic arene complexes (113). Furthermore, newly discovered proteins and enzymes serve as target of anticancer coordination complex design

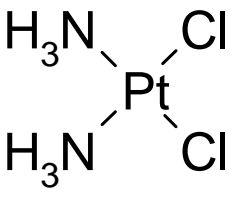

Figure 7. Structure of cisplatin. A coordination complex that is widely used in anticancer chemotherapy. (114). For instance, the target of tetrahedral $\mathrm{Au}(\mathrm{I})$ phosphine complexes displays a wide spectrum of anticancer activity in vivo, especially in cisplatin-resistant cell lines $(115,116)$. Their cytotoxicity is mediated by their ability to inhibit mitochondrial human glutathione reductase and thioredoxin reductase irreversibly (116). 
A number of studies have demonstrated that copper transporters (CTR1/2 and ATP7A/B) are responsible for transport of cisplatin (71-74). Therefore, we tried to combine the advantages of platinum- and copper-based coordination complexes and resistance modifier steroid compounds in a wish to overcome drug resistance in a cisplatin-resistant human ovarian cancer cell line directly through copper transporters and in a doxorubicinresistant human $\mathrm{ABCB} 1$-expressing mouse lymphoma cell line. In our experiments other compounds of synthetic (hydantoin derivatives) and natural origin (steroidal alkaloids, saponins and phenolic components) were also investigated to reverse drug resistance.

Cancer is a consequence of genetic changes in certain tumor suppressor genes and proto-oncogenes that can be hereditary in many cancer types, such as breast and ovarian cancer (117-119). Resistance can also be caused by SNPs of membrane transporters $(36,37)$. Evidence of a relationship between a specific $A B C B 1$ haplotype and altered pharmacokinetics may make it possible to predict individual sensitivity to many drugs which are ABCB1 substrates (120). Furthermore, the overexpression of BCL2 and ABCB1 may predict the inefficacy of paclitaxel-based chemotherapy (121). In multivariate analyses, the group of women with P53 genetic alterations (rs1042522), who did not receive adjuvant radiation therapy, had a 5.9-fold increased risk of death (95\% CI: 1.5-22.7) compared to women whose tumors lacked $P 53$ alterations and did not receive adjuvant radiation therapy (122). In another study, a clear trend for a higher response rate to paclitaxel and platinum-based therapy, and longer progression-free and overall survival were observed in wild-type P53 and heterozygous ovarian cancer patients compared to patients with mutant P53 (123). The correlation between the response to paclitaxel and the SNP of ABCB1 rs2032582 has also been verified in ovarian cancer (124). Furthermore, other genes of the apoptotic pathway can be important to determine cancer risk and disease outcome (125). Therefore, we tried to define the relationship between certain SNPs and cancer, complementing our knowledge about sequence - protein function relationships of the examined genes and proteins. In our examinations, SNPs of $A B C B 1, P 53, B A X$, and BCL2, were studied in order to find genetic differences between cancer patient and healthy volunteer groups. 


\section{AIMS OF THE RESEARCH}

The main aim of our study was to evaluate the effects of synthetic and natural compounds on drug resistance in a hormone-independent cisplatin-resistant human ovarian cancer cell line (A2780cis) and in a human ABCB1-transfected doxorubicin-resistant mouse T-lymphoma cell line (MDR). Furthermore, distributions of certain single nucleotide polymorphisms in cancer-related genes were also investigated.

The goals of the study are as follows:

1. Characterization of the examined cell lines (A2780/A2780cis and PAR/MDR) by immunocytochemistry using specific monoclonal antibodies to determine the expression of certain proteins, such as ABCB1, MRP1, estrogen and progesterone receptors.

2. Determination of the antiproliferative effects of compounds (semisteroids and platinum/copper complexes, hydantoin derivatives, steroidal alkaloids of Veratrum lobelianum, V. nigrum and Peganum nigelastrum, saponins and phenolic components of Tribulus terrestris and Smilax excelsa) in A2780cis and/or MDR cells.

3. Evaluation of the MDR reversal effects of compounds (semisteroids and platinum/copper complexes, hydantoin derivatives, steroidal alkaloids of Veratrum lobelianum, V. nigrum and Pergamum nigelastrum, saponins and phenolic components of Tribulus terrestris and Smilax excelsa) in A2780cis and/or MDR cell lines

4. Combination of selected resistance modifiers and some anticancer agents (doxorubicin and cisplatin) to determine their mode of interaction by checkerboard microplate method in A2780cis and MDR cells.

5. Apoptosis induction in A2780cis and MDR cells by selected semisubstituted steroids, and their platinum and copper complexes.

6. Evaluation of allele distribution of single nucleotide polymorphisms of cancerrelated genes by PCR-RFLP. 


\section{MATERIALS AND METHODS}

\section{Cell cultures}

PAR/MDR. Parental (PAR) mouse T-cell lymphoma cells (ECACC cat. no. 87111908, U.S. FDA, Silver Spring, MD, USA) were transfected with $\mathrm{pHa}$ ABCB1/A retrovirus, as described previously $(126,127)$. The human ABCB1-expressing cell line L5178Y (MDR) was selected by culturing the infected cells with $60 \mathrm{ng} / \mathrm{ml}$ colchicine to maintain the expression of the MDR phenotype. The PAR and its subline MDR were cultured at $37^{\circ} \mathrm{C}$ in McCoy's 5A media (Sigma-Aldrich Co., St. Louis, MO, USA) supplemented with 10\% heat-inactivated horse serum (H1270, Sigma-Aldrich Co.), L-glutamine 200 mM (Invitrogen Corp., Carlsbad, CA, USA) and penicillin-streptomycin mixture (Sigma-Aldrich Co.) in 100U/1 and $100 \mathrm{mg} / \mathrm{l}$ concentration, respectively. The media for culturing the $\mathrm{ABCB} 1$ gene-transfected cell line is complemented with colchicine $(60 \mathrm{ng} / \mathrm{ml}$, Sigma-Aldrich Co.) to maintain the ABCB1expressing phenotype. The mouse lymphoma cell lines were cultured in a $5 \% \mathrm{CO}_{2}$ incubator at $37^{\circ} \mathrm{C}$.

A2780/A2780cis. A2780cis cell line (ECACC cat. no. 93112517, Salisbury, UK) has been developed by chronic exposure of the parental A2780 human ovarian cancer cell line to increasing concentrations of cisplatin $(34,128,129)$. These cell lines were cultured in RPMI (Roswell Park Memorial Institute) 1640 media (Sigma-Aldrich Co.) supplemented with 10\% heat-inactivated fetal bovine serum (10106-169, GIBCO, Invitrogen Corp.), L-glutamine $200 \mathrm{mM}$ and penicillin-streptomycin mixture in $100 \mathrm{U} / 1$ and $100 \mathrm{mg} / \mathrm{l}$ concentration, respectively. In order to retain resistance of A2780cis cells, cisplatin (Teva Pharma Kft., Budapest, Hungary) was added to the media in every $2-3$ passages at $1 \mu \mathrm{M}$ final concentration. The ovarian cancer cell lines were maintained in a $5 \% \mathrm{CO}_{2}$ incubator at $37^{\circ} \mathrm{C}$.

\section{Compounds}

Semisubstituted steroids and their derivatives in complex with platinum and copper (I). A number of steroid-type molecules have been described previously to prevent drug and multidrug resistance in cancer $(130,131)$. In our study, thirty-five modified steroid (1-35) derivatives were examined in A2780cis and MDR cells, provided by Prof. Irén Vincze (Department of Organic Chemistry, University of Szeged) and Dr. Csaba Somlai (Department of Medical Chemistry, University of Szeged) (Appendix 1) (132-140). Then, three selected compounds $(4,5,25)$ and their copper $(4 \mathrm{C}, 5 \mathrm{C}, \mathbf{2 5 C})$ and platinum complexes $(4 \mathrm{P}, 5 \mathrm{P}, 25 \mathrm{P})$ were investigated. These compounds were provided by Dr. Imre Labádi (Department of Inorganic and Analytical Chemistry, University of Szeged).

Hydantoin derivatives (II). Various aspects of the biochemical and pharmacological properties of hydantoin derivatives have been studied by their fungicidal, herbicidal and antiinflammatory properties $(141,142)$. The anticancer activity of these compounds has received little attention. Recently, the cytotoxic activity of spirohydantoin derivatives was tested on ovarian and breast cancer cell lines, furthermore, it was shown that two spirohydantoin derivatives inhibited cell growth and induced apoptosis in leukemia cells (143-148). In our experiments, thirty hydantoin derivatives (SZ-2, SZ-7, LL-9, BS-1, JH-63, MN-3, TD-7k, GG-5k, P3, P7, P10, P11, RW-15b, AD-26, RW-13, AD-29, KF-2, PDPH-3, Mor-1, KKXV, Thioam-1, JHF-1, JHC-2, JHP-1, Fur-2, GL-1, GL-7, GL-14, GL-16, GL-18) were investigated in MDR cells. These compounds were provided by Prof. Dr. Katarzyna Kieć- 
Kononowich and Dr. Jadwiga Handzlik (Department of Technology and Biotechnology of Drugs, Jagiellonian University, Cracow, Poland) (Appendix 2).

Steroidal alkaloids of Veratrum and Peganum species (III, IV). Plants from genus Veratrum (Liliaceae) and genus Peganum (Zygophyllaceae) has been traditionally used as medicinal substances by Mongolia for a long history. The alkaloids have extensive pharmacological actions including anticancer, anti-Alzheimer's disease, anti-diabetes, antimicrobial, antiinflammatory activities $(149,150)$. Therefore, we investigated nine alkaloids (A1-9): neogermitrine (A1), verabenzoamine (A2), veratroilzigadenine (A3), 15-O-(2methylbutyroyl)germine (A4), veralosinine (A5), veranigrine (A6), deoxypeganine (A7), harmine (A8) and peganine (A9) in MDR cells isolated previously from the roots and rhizomes of three Mongolian species (Veratrum lobelianum, V. nigrum, Peganum nigelastrum) by Veselin Christov et al. and Antoaneta Ivanova et al. (Institute of Organic Chemistry with Centre of Phytochemistry, Bulgarian Academy of Sciences, Sofia, Bulgaria) (Appendix 3) (151-153).

Saponins and phenolic components of Tribulus terrestris and Smilax excelsa (V). Saponins are generally found in the roots, flowers and seeds of higher plants and have long been used against various diseases contributing to pest and pathogen resistance $(154,155)$. Therefore, we evaluated six steroidal saponins (S-4, S8, S9), a mixture of three saponin isomers (S5-7), and two phenolic components (S10, S11) isolated from the saponin fractions of Tribulus terrestris (Zygophyllaceae) and Smilax excelsa (Smilacaceae) as possible MDR modifiers in MDR cells. These compounds were provided by Antoaneta Ivanova et al. (Institute of Organic Chemistry with Centre of Phytochemistry, Bulgarian Academy of Sciences, Sofia, Bulgaria) (Appendix 4) (156-163).

\section{Methods}

\subsection{Immunocytochemistry}

The immunocytochemical investigations were carried out at the National Institute of Oncology (Budapest, Hungary). Cancer cells were cultured and resuspended in serum-free media to a density of $1 \times 10^{6}$ cells $/ \mathrm{ml}$. $100 \mu \mathrm{l}$ cell suspension was centrifuged at $1.000 \mathrm{rpm}$ for 5 min by a Shandon Cytospin 3 centrifuge (Thermo Fisher Scientific Inc., Weltham, MA, USA), then Giemsa-stain was applied for one of each sample. The slides were fixed in acetone at $-20^{\circ} \mathrm{C}$ for $10 \mathrm{~min}$ and were washed for $5 \mathrm{~min}$ in Tris-buffered saline buffer $(1 \mathrm{x}$ TBS: $50 \mathrm{mM}$ Tris- $\mathrm{HCl} \mathrm{pH} 7.4$ and $150 \mathrm{mM} \mathrm{NaCl}$ ). The latter investigations were performed in a wet chamber.

The following monoclonal antibodies (MABs) were applied to detect the cell membrane proteins: NCL-JSB1 (for ABCB1; Novocastra ${ }^{\mathrm{TM}}$, Leica Biosystems Newcastle Ltd., Newcastle Upon Tyne, UK), NCL-PGLYm (for ABCB1; Novocastra ${ }^{\mathrm{TM}}$ ), NCL-MRP1 (for MRP1; Novocastra ${ }^{\mathrm{TM}}$ ), NCL PGR 312 (for progesterone receptor; Novocastra ${ }^{\mathrm{TM}}$ ), SP1 RM 9101-S (for estrogen receptor; Neomarkers, Thermo Fisher Scientific Inc.). MCF-7 breast cancer cell line (ECACC nr. 86012803) was applied as a control. The smears were washed with phosphate-buffered saline (PBS: $\mathrm{Na}_{2} \mathrm{HPO}_{4} 1.48 \mathrm{~g}, \mathrm{KH}_{2} \mathrm{PO}_{4} 0.43 \mathrm{~g}, \mathrm{NaCl} 7.2 \mathrm{~g}$, solved in

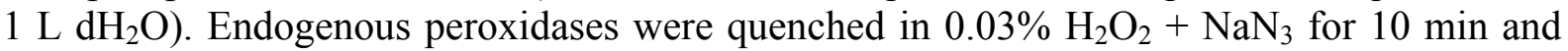
washed with PBS. The samples were incubated for $1 \mathrm{~h}$ at room temperature with primary MABs, $100 \mu \mathrm{l}$ of the MABs (anti-ABCB1, anti-MRP1 10x; anti-estrogen 200x; antiprogesterone $180 \mathrm{x}$ diluted in $\mathrm{PBS})$ and the positive control cytokeratinase (25x diluted in PBS) were added. Then, DAKO Cytomation EnVision+ System-HRP (AEC) kit (DAKO 
North America Inc., Carpinteria, CA, USA) was applied according to manufacturer's instructions to detect the red end-product of the cleavage by horseradish peroxidase (HRP) under microscope. Finally, haematoxylin-eosin staining was carried out and cover slips placed over the slides containing the samples (wet mounts) with Dako Cytomation Faramount Adequous Mounting and photographed with a Nikon Microphot-SA + UFX-DX instrument (Nikon Corp., Tokyo, Japan) to yield 100x, 200x and 400x magnifications.

\subsection{Assay for antiproliferative effect}

The effects of increasing concentrations of the drugs on cell growth were examined in 96-well flat-bottomed microtitre plates. The stock compounds were dissolved in DMSO to yield a starting concentration of $50 \mu \mathrm{g} / \mathrm{ml}$ in a final volume of $150 \mu \mathrm{l}$. Two-fold dilutions with $2 \%$ DMSO and $50 \mu \mathrm{g} / \mathrm{ml}$ of compounds were made; the final concentration of DMSO was $0.0156 \%$ and the final concentration of the compound was $1.5625 \mu \mathrm{g} / \mathrm{ml}$. DMSO was used as a control. A total of $6 \times 10^{3}$ cells in $50 \mu 1$ of media were then added to each well, with the exception of the media control wells. The culture plates were further incubated in a $5 \% \mathrm{CO}_{2}$ incubator at $37^{\circ} \mathrm{C}$ for $72 \mathrm{~h}$. At the end of the incubation, $15 \mu \mathrm{l}$ of MTT solution $(3-(4,5-$ dimethyiltiazol-2-yl)-2,5-diphenyltetrazolium bromide (MTT) thiazolyl blue solved in PBS at a final concentration of $5 \mathrm{mg} / \mathrm{ml}$ ) were added to each well. After further incubation at for $4 \mathrm{~h}$, $100 \mu 1$ of sodium dodecyl sulphate (SDS) solution $(10 \%+1 \mathrm{~N} \mathrm{HCl})$ were added to each well and the plates were further incubated in a $5 \% \mathrm{CO}_{2}$ incubator at $37^{\circ} \mathrm{C}$ overnight. The cell growth was determined by measuring the optical density (OD) at $550 \mathrm{~nm}$ (ref. $630 \mathrm{~nm}$ ) with a Multiscan EX ELISA reader (Thermo Fisher Scientific Inc.). Inhibition of cell growth was determined as a percentage according to the formula (164):

$$
100-\left[\frac{\text { ODtreated cells-OD medium control }}{\text { ODcell control-ODmediumcontrol }} \times 100\right]
$$

\subsection{Assay for reversal of MDR in tumor cells by flow cytometry}

The cells were adjusted to a density of $2 \times 10^{6}$ cells $/ \mathrm{ml}$, resuspended in serum-free McCoy's $5 \mathrm{~A}$ media and distributed in $0.5 \mathrm{ml}$ aliquots $\left(1 \times 10^{6}\right.$ cells $)$ into Eppendorf centrifuge tubes. The cells were incubated in the presence of compounds for $10 \mathrm{~min}$ at room temperature. Then, indicator ABCB1-substrate rhodamine 123 (R123) (Sigma-Aldrich Kft, Budapest, Hungary) was added to each sample at a final concentration of $10 \mu \mathrm{g} / \mathrm{ml}$ and the cells were incubated for a further $20 \mathrm{~min}$ at $37^{\circ} \mathrm{C}$ in water bath, washed twice and resuspended in $0.5 \mathrm{ml}$ phosphate-buffered saline (PBS) for analysis. The fluorescence of the cell population was measured in FL1 at $540 \mathrm{~nm}$ (ref. $630 \mathrm{~nm}$ ) wavelength with a FACS Star Plus flow cytometer (Beckton, Dickinson and Company, Franklin Lakes, NJ, USA). Verapamil hydrochloride (EGIS Pharmaceuticals PLC, Budapest, Hungary) was used as a positive control in MDR cells at a final concentration of $10 \mu \mathrm{g} / \mathrm{ml}$ (Appendix 5) (59).

The results presented are obtained from a representative flow cytometric experiment in which $1 \times 10^{4}$ individual cells of the population were evaluated for the amount of the retained R123 (Appendix 6) (165). The percentage of mean fluorescence intensity was calculated for the PAR/MDR and A2780/A2780cis cell lines; treated cells were compared with the untreated ones. Fluorescence activity ratio (FAR) was calculated via the following equation on the basis of the measured fluorescence values:

$$
F A R=\frac{\text { MDR treated } / \text { MDR control }}{\text { parental treated } / \text { parental control }}
$$




\subsection{Assay for combination of chemotherapy}

A checkerboard microplate method was applied to study the mode of interactions of the resistance modifiers and the anticancer agent doxorubicin (Ebewe Pharma, Unternach, Austria) on MDR cells or cisplatin (Teva Pharma Kft., Budapest, Hungary) on A2780cis cells as an in vitro model of combination chemotherapy (Appendix 7, 8) $(166,167)$. The combinations were carried out in a final volume of $200 \mu$ l. Doxorubicin or cisplatin (A) was measured into the microtitre plate in a horizontal direction in two-step dilutions, the highest final concentration was $8 \mu \mathrm{g} / \mathrm{ml}$ or $20 \mu \mathrm{g} / \mathrm{ml}$, respectively. The resistance modifiers (B) were diluted vertically in the microtitre plate in two-step dilutions. The cell suspension in the appropriate tissue culture media was distributed into each well in $50 \mu$ containing $1 \times 10^{4}$ MDR cells or $2 \times 10^{4}$ A2780cis cells. The plates were incubated in a $5 \% \mathrm{CO}_{2}$ incubator at $37^{\circ} \mathrm{C}$ for $48 \mathrm{~h}$. The cell growth rate was determined after MTT staining and the intensity of the blue color was measured with a Multiscan EX ELISA reader. Drug interactions were evaluated according to the following system:

$$
\begin{aligned}
& \mathrm{FIC}_{\mathrm{A}}=\mathrm{IC}_{50 \mathrm{~A} \text { combination }} / \mathrm{IC}_{50 \mathrm{~A} \text { alone }} \\
& \mathrm{FIC}_{\mathrm{B}}=\mathrm{IC}_{50 \mathrm{~B} \text { combination }} / \mathrm{IC}_{50 \mathrm{~B} \text { alone }}
\end{aligned}
$$

where IC $=$ inhibitory concentration and FIC $=$ fractional inhibitory concentration. FIX $=$ $\mathrm{FIC}_{\mathrm{A}}+\mathrm{FIC}_{\mathrm{B}}$, where FIX $=$ fractional inhibitory index. FIX $<0.5$ indicates synergism, $0.5<$ FIX $<4$ indicates no interaction (addition), and FIX $>4$ indicates antagonism between the anticancer drug and the potential MDR modifier agent $(166,167)$.

\subsection{Assay for apoptosis induction}

Apoptosis induction in the presence of various compounds was determined in MDR and A2780cis cells $(168,169)$. The MDR cells were adjusted to a density of $1 \times 10^{6}$ cells $/ \mathrm{ml}$ and were distributed in $0.5 \mathrm{ml}$ aliquots into microcentrifuge tubes. Then, drugs were added to the samples to determine their activity on apoptosis induction. 12H-benzo(a)phenothiazine (M627) was used as a control of apoptosis at a final concentration of $50 \mu \mathrm{g} / \mathrm{ml}$ (Appendix 9) (170). The MDR cells were incubated at $37^{\circ} \mathrm{C}$ for $45 \mathrm{~min}$ in water bath, then washed twice with PBS and resuspended in $0.5 \mathrm{~mL}$ McCoy's $5 \mathrm{~A}$ media. The $24 \mathrm{~h}$ incubation was carried out in a $5 \% \mathrm{CO}_{2}$ incubator at $37^{\circ} \mathrm{C}$.

The suspension of A2780cis ovarian cancer adherent cells were diluted to $1.5 \times 10^{6}$ cells $/ \mathrm{ml}$ and distributed into 24-well culture plates for $4 \mathrm{~h}$ in $750 \mu \mathrm{l}$ aliquots to let the cells attach. Then, the compounds were added, M627 was used as a control for apoptosis at a final concentration of $50 \mu \mathrm{g} / \mathrm{ml}$, and $2 \%$ paraformaldehide (PFA) was used as a control for necrosis. Apoptosis induction on the A2780cis cells was conducted over a period of up to $3 \mathrm{~h}$ in the presence and absence of the compounds. The samples were then washed with PBS and resuspended in RPMI media. The $24 \mathrm{~h}$ incubation was carried out in a $5 \% \mathrm{CO}_{2}$ incubator at $37^{\circ} \mathrm{C}$.

MDR cells were transferred into $1.5 \mathrm{ml}$ Eppendorf centrifugation tubes. The apoptosis assay was carried out according to the Rapid Annexin V Binding Protocol of Annexin VFITC Apoptosis Detection Kit (Calbiochem, Merck KGaA, Darmstadt, Germany). Briefly, after transferring the MDR cells into Eppendorf centrifugation tubes, $10 \mu \mathrm{l}$ of Media Binding Buffer was added to each sample, then $1.2 \mu 1$ Annexin V (AV)-FITC (fluorescein isothiocyanate) was measured to the samples. In case of A2780cis cells, $15 \mu 1$ of Media Binding Buffer and $1.2 \mu \mathrm{l} \mathrm{AV-FITC} \mathrm{was} \mathrm{added} \mathrm{into} \mathrm{the} \mathrm{wells} \mathrm{of} \mathrm{the} \mathrm{24-well} \mathrm{plate.} \mathrm{The}$ samples were incubated at room temperature for $15 \mathrm{~min}$ in the dark. Then, after washing the 
cell with PBS, they were centrifuged at $2000 \mathrm{~g}$ for $3 \mathrm{~min}$ at room temperature, and the media was removed. The cells were resuspended in 0.5 ice-cold 1x Binding Buffer, and stored on ice. $10 \mu \mathrm{l}$ propidium iodide (PI, final concentration $1.5 \mu \mathrm{g} / \mathrm{ml}$ ) was added to the samples, and analyzed immediately by measuring the fluorescence activity. AV was measured in FL1 at $540 \mathrm{~nm}$, and PI was measured in FL3 at $680 \mathrm{~nm}$ wavelength. Twenty thousand cells of the gated population were measured from each sample by a FACS Star Plus flow cytometer (Beckton, Dickinson and Company). Degree of apoptosis was determined by comparison of the control population where the $\%$ of AV binding does not exceed $5 \%$ and the experimental population.

The background of this apoptosis assay is that FITC-labeled Annexin V (AV) binds to phosphatidyl serine, which membrane component is translocated to the outer leaflet of the membrane during apoptosis $(168,169)$. Since membrane permeabilization is observed in necrosis, necrotic cells will also bind AV. FITC signal can be detected in FL1 channel by flow cytometry. PI is used to distinguish between viable, early apoptotic, and necrotic/late apoptotic cells, because PI is excluded from viable and apoptotic cells. PI is a DNAintercalating agent, once it is excited, it fluoresces red, which can be detected in FL2/FL3 channels by flow cytometry. In the absence of phagocytosis, final stages of apoptosis involve necrotic-like disintegration of the total cell, thus, cells in late apoptosis will be labeled with both FITC and PI.

\subsection{DNA extraction from human blood for PCR}

Ethical Permission was approved by the Human Investigation Review Board at the Albert Szent-Györgyi Clinical Centre (Szeged, Hungary), and all patients gave their inform consents to the examination. In our experiments most of the cancer patients (69 of 88) selected for SNP analysis had been treated by chemotherapy previously, the therapies were carried out according to the variable protocols of certain cancer types. The patients were divided into two groups: gynecological cancer group (ovarian and cervical cancer, $n=31$ ), and a mixed cancer group $(n=57)$. A group of healthy volunteers $(n=99)$ was applied as control group.

Venous blood was taken into $3 \mathrm{ml}$ tubes anticoagulated with ethylenediaminetetraacetic acid (EDTA) at the Blood Transfusion Centre at the Albert Szent-Györgyi Clinical Centre. The deoxyribonucleic acid (DNA) extraction was carried out by a modified salting out protocol (171). Briefly, $400 \mu$ l blood was resuspended in a $1.5 \mathrm{ml}$ Eppendorf centrifugation tube with $600 \mu \mathrm{l}$ distilled water and $250 \mu \mathrm{l}$ of nuclei lysis buffer $(50 \mu \mathrm{M}$ Tris- $\mathrm{HCl} \mathrm{pH} 7.5$, $22.7 \%$ Triton $\mathrm{X}-100,20 \mu \mathrm{M} \mathrm{MgCl}_{2}$ and $140 \mu \mathrm{M}$ saccharose). After washed twice with $600 \mu 1$ distilled water $(10.000 \mathrm{rpm}, 3 \mathrm{~min})$, the cell lysates were digested overnight at $37^{\circ} \mathrm{C}$ with 40 $\mu 1$ of $10 \%$ sodium dodecyl sulphate (SDS), $80 \mu 15 x$ proteinase-K buffer $(0.3 \mathrm{M} \mathrm{NaCl}$ and 0.1 $\mathrm{M}$ EDTA pH 8.0) and $20 \mu \mathrm{l}$ of a proteinase $\mathrm{K}(20 \mathrm{mg} / \mathrm{ml}$, Fermentas, Thermo Fisher Scientific Inc.) solution. After complete digestion, $150 \mu \mathrm{l}$ of $5 \mathrm{M} \mathrm{Na}$-acetate was added to each tube and shaken vigorously for $15 \mathrm{sec}$, followed by centrifugation at $13.000 \mathrm{rpm}$ for $3 \mathrm{~min}$. The precipitated protein pellet was left at the bottom of the tube and the supernatant containing the DNA was transferred to another $1.5 \mathrm{ml}$ Eppendorf centrifugation tube. $600 \mu 1$ of pre-cooled isopropanol $\left(-20^{\circ} \mathrm{C}\right)$ was added to each tube and the tubes were inverted several times until the DNA precipitation. After centrifugation at $13.000 \mathrm{~g}$ for $3 \mathrm{~min}$, the supernatant was discarded and $800 \mu \mathrm{l}$ of pre-cooled ethanol $\left(-20^{\circ} \mathrm{C}, 70 \%\right)$ was added to the pellet. After the final centrifugation step at $13.000 \mathrm{~g}$ for $3 \mathrm{~min}$, the supernatant was discarded again, and the DNA was dried at room temperature. For the PCR experiments the DNA was dissolved in 
$25 \mu 1$ PCR-clean DNAse and RNAse free distilled-water (Fermentas). The concentration of the DNA was measured by NanoDrop ${ }^{\mathrm{TM}} 1000$ (Thermo Fisher Scientific Inc.).

\subsection{Evaluation of SNPs by PCR-RFLP}

These experiments were carried out at the Institute of Integrative and Comparative Biology. (University of Leeds, United Kingdom). Polymerase chain reaction - restriction fragment length polymorphism (PCR-RFLP) was applied to identify ABCB1 (rs2032582, rs 1045642), $P 53$ (rs1042522), BCL2 (rs4645878) and BAX (rs2279115) single nucleotide polymorphisms (SNPs) $(172,173)$. Each PCR was performed in a $20 \mu 1$ reaction mixture containing 10-100 ng of genomic DNA templates, $0.5 \mathrm{pM}$ of each primer (Sigma-Aldrich, St. Louise, MO, USA), $2 \mathrm{mM}$ of each deoxynucleoside triphosphate (Promega Corporation, Madison, WI, USA), 10x PCR buffer, $2.5 \mathrm{mM} \mathrm{MgCl}_{2}$, and $0.5 \mathrm{U}$ Thermus aquaticus (Taq) polymerase (BIOTAQ $^{\mathrm{TM}}$ Red DNA Polymerase, Bioline USA Inc., Taunton, MA, USA). The PCR profile consisted of an initial denaturation step of $96^{\circ} \mathrm{C}$ for $5 \mathrm{~min}, 35$ cycles of $96^{\circ} \mathrm{C}$ for $45 \mathrm{~s}, 56^{\circ} \mathrm{C}$ for $40 \mathrm{~s}$ and $72^{\circ} \mathrm{C}$ for $30 \mathrm{~s}$ and a final extension step of $72^{\circ} \mathrm{C}$ for $10 \mathrm{~min}$ in a 2720 Thermal Cycler (Applied Biosystems, CA, USA) $(172,173)$.

$A B C B 1, B A X, B C L 2$ and $P 53$ polymorphisms were examined by digesting $5 \mu 1$ of PCR product by $2 \mathrm{U}$ of restriction enzyme (New England Biolabs, Beverly, MA, USA) in a final volume of $10 \mu \mathrm{l}$ at $37^{\circ} \mathrm{C}$ overnight (BanI, DpnII, MspI, BccI) or at $60^{\circ} \mathrm{C} 4 \mathrm{~h}$ (BstuI), then evaluated by gel electrophoresis on $2 \%$ agarose gel (Sigma-Aldrich). The sequences of the primers and fragment length of selected SNPs are presented in Table I.

Table I. Cancer-related single nucleotide polymorphisms selected for SNP studies examined by PCR-RFLP.

\begin{tabular}{|c|c|c|c|c|c|}
\hline Gene & SNP & primer & sequence & $\mathrm{RE}$ & size $(b p)$ \\
\hline \multirow{4}{*}{$A B C B 1$} & \multirow{2}{*}{ rs2032582 } & MDR-9 (f) & "5`-TgCAggCTATAggTTCCAgg-3` & \multirow{2}{*}{ BanI } & \multirow{2}{*}{198,$26 ; \underline{224}$} \\
\hline & & MDR-10 (r) & 5`-TTTAgTTTgACTCACCTTCCCg-3` & & \\
\hline & \multirow{2}{*}{ rs 1045642} & MDR-11 (f) & 5`-TgTTTTCAgCTgCTTGATgg-3` & \multirow{2}{*}{ DpnII } & \multirow{2}{*}{158,$39 ; \underline{197}$} \\
\hline & & MDR-12 (r) & 5'-AAggCATgTATgTTggCCTC-3` & & \\
\hline \multirow{2}{*}{$B A X$} & \multirow{2}{*}{ rs2279115 } & BAX1 (f) & 5`-CATTAgAgCTgCgATTggACCg-3' & \multirow{2}{*}{ MspI } & \multirow{2}{*}{20,$89 ; \underline{109}$} \\
\hline & & BAX2 (r) & 5`-gCTCCCTCgggAggTTTggT-3` & & \\
\hline \multirow{2}{*}{ BCL2 } & \multirow{2}{*}{ rs4645878 } & BCL1 (f) & $5^{`}$-CTgCCTTCATTTATCCAgCA-3` & \multirow{2}{*}{ BccI } & \multirow{2}{*}{189,$111 ; \underline{300}$} \\
\hline & & BCL2 (r) & 5`-ggCggCAgATgAATTACAA-3` & & \\
\hline \multirow{2}{*}{ P53 } & \multirow{2}{*}{ rs 1042522} & P53A (f) & 5'-ATCTACAgTCCCCCTTgCCg-3` & \multirow{2}{*}{ BstUI } & \multirow{2}{*}{169,$127 ; \underline{296}$} \\
\hline & & P53B (r) & $5^{\prime}$-gCAACTgACCgTgCAAgTCA-3` & & \\
\hline
\end{tabular}

Rs: reference sequence number. $(f)$ and $(r)$ represents forward and reverse primers. RE: restriction endonuclease. $\mathrm{Bp}$ : base pair. Product size after digestion: wild type alleles digested, variant alleles undigested in italics underlined. Bases: A - adenine, $\mathrm{C}$ - cytosine, $\mathrm{g}$ - guanine, $\mathrm{T}$ - thymine. (Primer sequences were taken from Cascorbi, I et al. Clin. Pharmacol. Ther., 2001, 69: 169-74 (172); and Chen, K. et al. Carcinogenesis, 2007, 28 : 2008-2012 (173).)

\subsection{Statistical analysis}

Statistical analyses for comparison of genotype frequencies between groups were performed by using the $\chi^{2}$ (chi-square) test, and Fisher's exact test when the values in any of the cells of a contingency table was below 10 with only one degree of freedom. The relationship between genotypes and cancer is presented as the odds ratio (OR), with a 95\% confidence interval (CI). Genotype distributions and deviation from Hardy-Weinberg equilibrium (HWE) were tested separately for both cases and controls with SPSS (SPSS for Windows 16.0) and HWE calculator (174). All statistical tests were two-sided, a $P$ value of 0.05 was considered significant. Power and sample size (PS) was determined by the PS program version 3.0 (175). Linkage disequilibrium was measured between the two SNPs of ABCB1 by LDA software that was available at http://www.chgb.org.cn/lda/lda.htm (176). 


\section{RESULTS}

\section{Immunocytochemistry}

High level of $\mathrm{ABCB} 1$ expression was detected in the membrane of the doxorubicin-resistant ABCB1 gene-transfected mouse lymphoma (MDR) cell line, whereas in the cisplatin-resistant human ovarian cancer (A2780cis) cell line (Figure 8), and in the control cell lines (data not presented) ABCB1 expression was not detected. Aspecific staining of the cytoplasm was shown when using MRP1 specific monoclonal antibody (MAB) in both MDR and A2780cis cell lines (Figure 9). The expression of estrogen or progesterone hormone receptors was undetectable in A2780/cis and PAR/MDR cell lines, but it was visible in MCF-7 breast cancer control cell line (data not presented).
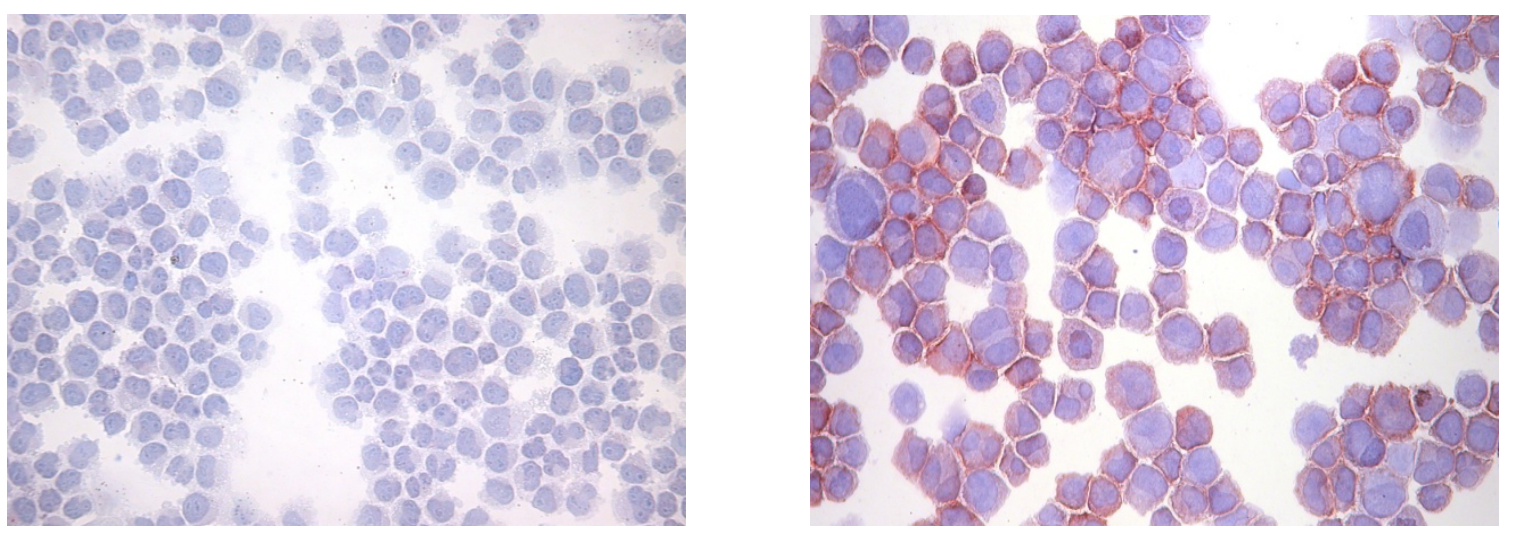

Figure 8. ABCB1 staining of ovarian cancer cells (A2780cis) (left) and human ABCB1-transfected mouse T-cell lymphoma (MDR) (right) cells by PGLYm monoclonal antibody (MAB). ABCB1 protein (red staining) was detectable only in MDR cells.
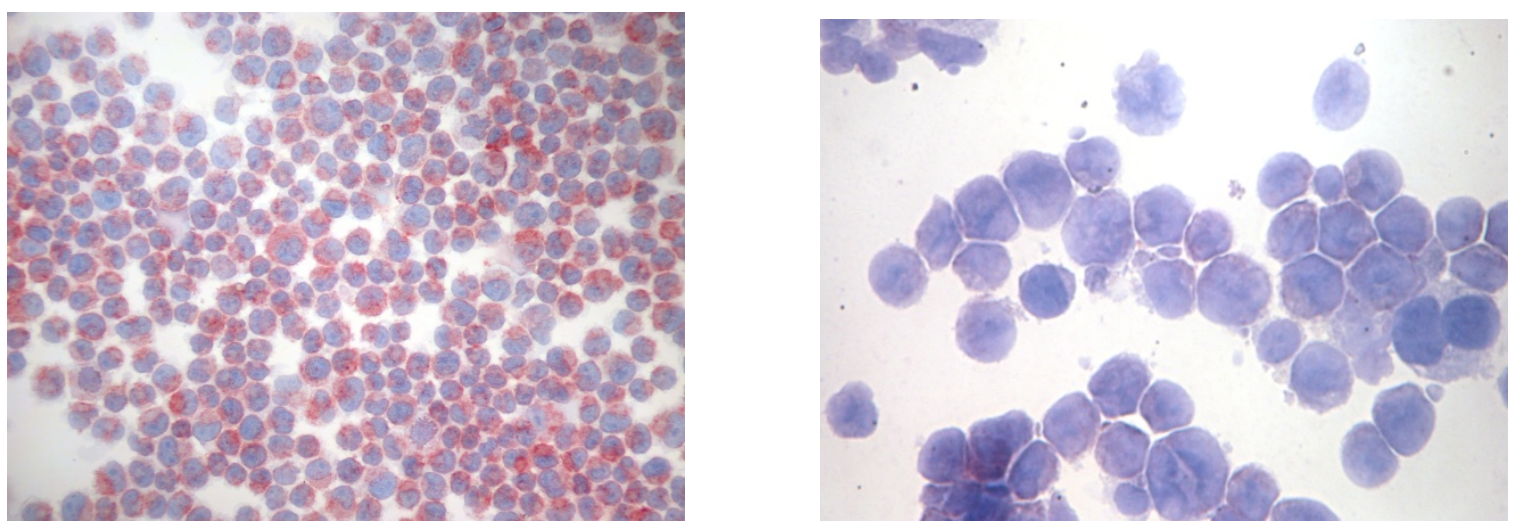

Figure 9. MRP1 aspecific red staining of the cytoplasm of ovarian cancer cells (A2780cis) (left) and human ABCB1-transfected mouse T-cell lymphoma (MDR) (right) cells by NCL-MRP1 monoclonal antibody (MAB). 


\section{Effects of selected compounds on cancer cells}

\subsection{Antiproliferative effect of different compounds on MDR and A2780cis cells.}

\section{Semisubstituted steroids and selected platinum and copper coordination complexes (I).} Thirty-five modified steroid (1-35) derivatives (androstanes, -enes, pregnanes, -enes, estratienes and special D-ring dervatives) were examined in A2780cis and MDR cells to determine their antiproliferative activity. In A2780cis cells, three groups of steroid derivatives were determined according to the level of the effective concentrations: strong antiproliferative effect $0<\mathrm{IC}_{50}<10 \mu \mathrm{g} / \mathrm{ml}$ (compounds 21-24, 34), moderate antiproliferative effect $10<\mathrm{IC}_{50}<50 \mu \mathrm{g} / \mathrm{ml}$ (compounds 2, 9-11, 15, 17, 18, 20, 25, 27-29, 33) and no antiproliferative effect $\mathrm{IC}_{50}>50 \mu \mathrm{g} / \mathrm{ml}(\mathbf{1}, \mathbf{3 - 8}, \mathbf{1 2 - 1 4}, \mathbf{1 6}, \mathbf{1 9}, \mathbf{2 6}, \mathbf{3 0 - 3 2}, \mathbf{3 5})$. In MDR cells, three groups of compounds were determined with the same concentration intervals: strong (compounds 10-12, 18, 33, 34), moderate (compounds 5, 6, 9, 13, 16, 22, 32, 35) and no antiproliferative effect $(\mathbf{1 - 4}, \mathbf{7}, \mathbf{8}, \mathbf{1 4}, \mathbf{1 5}, \mathbf{1 7}, \mathbf{1 9 - 2 1 , 2 3 - 3 1 )}$ (Table II, page 26).

Then, three interesting compounds $(\mathbf{4}, \mathbf{5}, \mathbf{2 5})$ were selected to examine their platinum(IV)-chloride (platinum) and copper(II)-perchlorate (copper) coordination complexes (4C, 5C, 25C and 4P, 5P, 2P) (Table III, page 27). The basis for the selection of these compounds was partly due to their proliferation inhibitory efficacy: compound $\mathbf{2 5}$ was effective in A2780cis cells; compound $\mathbf{5}$ was effective in MDR cells; but compound $\mathbf{4}$ was not effective in either of these two cell types. The other selection criterion was the MDR reversal activity: compounds $\mathbf{5}$ and $\mathbf{2 5}$ were effective in both cell lines, but compound $\mathbf{4}$ was not effective in either of them.

In A2780cis cells, only copper-steroid complexes $(\mathbf{4 C}, \mathbf{5 C}, \mathbf{2 5 C})$ were found to be better inhibitors of cell proliferation than steroids $(\mathbf{4}, \mathbf{5}, \mathbf{2 5})$ alone. Since the steroid-based compounds were dissolved in DMSO which completely inhibits cell proliferation in 2-4\% concentration in the examined cell lines, and there is a solubility limit for these compounds, the $\mathrm{IC}_{50}$ values that exceeded $50 \mu \mathrm{g} / \mathrm{ml}$ could not be calculated. In MDR cells, all of the complexes inhibited cell proliferation as compared to the steroids applied alone, whose effect is represented by the lower $\mathrm{IC}_{50}$ values.

As a general statement, copper-steroid complexes $(\mathbf{4 C}, \mathbf{5 C}, \mathbf{2 5 C})$ seem to be better inhibitors of cell proliferation than platinum-steroid complexes (4P, 5P, 22P) in both A2780cis and MDR cell lines. 
Table II. The effects of semisubstituted steroids (1-35) on cell proliferation $\left(\mathrm{IC}_{50}\right)$ and drug resistance (FAR) in ovarian cancer (A2780cis) and mouse T-cell lymphoma (MDR) cells.

\begin{tabular}{|c|c|c|c|c|}
\hline \multirow{2}{*}{ compounds } & \multicolumn{2}{|c|}{ A2780cis } & \multicolumn{2}{|c|}{ MDR } \\
\hline & $\mathrm{IC}_{50}(\mu \mathrm{g} / \mathrm{ml})$ & FAR & $\mathrm{IC}_{50}(\mu \mathrm{g} / \mathrm{ml})$ & FAR \\
\hline verapamil & 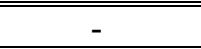 & 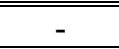 & - & $11.57 \bullet$ \\
\hline 1 & $>50$ & 0.86 & $>50$ & 1.38 \\
\hline 2 & $31.41 \mathbf{\Delta}$ & $1.68 \bullet$ & $>50$ & $24.48 \bullet$ \\
\hline 3 & $>50$ & 0.99 & $>50$ & 2.67 \\
\hline 4 & $>50$ & 0.81 & $>50$ & 1.59 \\
\hline 5 & $>50$ & $1.84 \bullet$ & $25.87 \boldsymbol{\Delta}$ & $7.41 \bullet$ \\
\hline 6 & $>50$ & $1.72 \bullet$ & $47.1 \mathbf{\Delta}$ & $55.11 \bullet$ \\
\hline 7 & $>50$ & 0.92 & $>50$ & $17.59 \bullet$ \\
\hline 8 & $>50$ & 1.06 & $>50$ & 2.39 \\
\hline 9 & $13.77 \mathrm{~A}$ & 1.02 & $15.05 \mathrm{~A}$ & 2.38 \\
\hline 10 & $19.97 \boldsymbol{\Delta}$ & 0.97 & $9.05 \bullet$ & $7.39 \bullet$ \\
\hline 11 & $10.84 \Delta$ & $1.26 \Delta$ & $4.33 \bullet$ & $15.84 \bullet$ \\
\hline 12 & $>50$ & $2.67 \bullet$ & $6.97 \bullet$ & $9.31 \bullet$ \\
\hline 13 & $>50$ & $1.37 \mathbf{\Delta}$ & $42.56 \Delta$ & 1.85 \\
\hline 14 & $>50$ & 1.07 & $>50$ & 1.52 \\
\hline 15 & $37.27 \boldsymbol{\Delta}$ & $1.39 \Delta$ & $>50$ & 0.94 \\
\hline 16 & $>50$ & 0.92 & $12.63 \Delta$ & 1.30 \\
\hline 17 & $21.84 \boldsymbol{\Delta}$ & 0.78 & $>50$ & $5.28 \bullet$ \\
\hline 18 & $14.19 \Delta$ & 0.99 & $5.42 \bullet$ & $11.45 \bullet$ \\
\hline 19 & $>50$ & 0.90 & $>50$ & $12.90 \bullet$ \\
\hline 20 & $18.14 \Delta$ & 0.92 & $>50$ & 3.55 \\
\hline 21 & $3.01 \bullet$ & 0.98 & $>50$ & $56.48 \bullet$ \\
\hline 22 & $9.99 \bullet$ & $1.71 \bullet$ & $28.67 \boldsymbol{\Delta}$ & $55.22 \bullet$ \\
\hline 23 & $3.56 \bullet$ & $1.11 \boldsymbol{\Delta}$ & $>50$ & $92.82 \bullet$ \\
\hline 24 & $7.21 \bullet$ & $1.22 \Delta$ & $>50$ & $9.62 \bullet$ \\
\hline 25 & $14.81 \boldsymbol{\Delta}$ & $3.40 \bullet$ & $>50$ & $92.82 \bullet$ \\
\hline 26 & $>50$ & 0.83 & $>50$ & 3.17 \\
\hline 27 & $22.05 \Delta$ & $2.19 \bullet$ & $>50$ & $17.04 \bullet$ \\
\hline 28 & $33.83 \Delta$ & 0.74 & $>50$ & 2.73 \\
\hline 29 & $23.02 \Delta$ & 0.52 & $>50$ & $35.23 \bullet$ \\
\hline 30 & $>50$ & 0.61 & $>50$ & $36.86 \bullet$ \\
\hline 31 & $>50$ & 0.99 & $>50$ & 1.21 \\
\hline 32 & $>50$ & 0.44 & $22.17 \boldsymbol{\Delta}$ & $7.29 \bullet$ \\
\hline 33 & $17.18 \Delta$ & $1.38 \mathbf{\Delta}$ & $5.53 \bullet$ & $15.23 \bullet$ \\
\hline 34 & $0.26 \bullet$ & 0.29 & $0.86 \bullet$ & $8.05 \bullet$ \\
\hline 35 & $>50$ & 0.42 & $15.55 \Delta$ & $23.40 \bullet$ \\
\hline DMSO & $1.78 \%$ & 0.64 & $2.21 \%$ & 0.79 \\
\hline
\end{tabular}

The flow cytometric results are from one representative experiment in which $1 \times 10^{4}$ cells were investigated. The samples were tested in $40 \mu \mathrm{g} / \mathrm{ml}$ final conc. FAR: fluorescence activity ratio. Positive control verapamil $(10 \mu \mathrm{g} / \mathrm{ml})$ and solvent control DMSO (2\%) were applied in the flow cytometric experiments. The most effective proliferation inhibitors $\left(\mathrm{IC}_{50}<10 \mu \mathrm{g} / \mathrm{ml}\right)$ and those with the higher FAR values (MDR: over 5.0, A2780cis: over 1.49) are identified with solid circles $(\bullet)$, the moderately effective proliferation inhibitors $\left(10<\mathrm{IC}_{50}<50 \mu \mathrm{g} / \mathrm{ml}\right)$ and compounds with moderate FAR values (A2780cis: 1.1-1.5) are signed with filled triangles ( $\mathbf{\Delta}$ ). 
Table III. The effects of selected steroid derivatives $(4, \mathbf{5}, \mathbf{2 5})$ and their complexes with platinum(IV)-chloride and copper(II)-perchlorate $(\mathbf{4 C}, \mathbf{5 C}, \mathbf{2 5 C}$ and $\mathbf{4 P}, \mathbf{5 P}, \mathbf{2 5 P})$ on cell proliferation $\left(\mathrm{IC}_{50}\right.$ ), drug resistance (FAR) and their interaction with anticancer drugs (FIX) in A2780cis and MDR cells.

\begin{tabular}{|c|c|c|c|c|c|c|c|c|c|c|c|}
\hline \multirow[b]{2}{*}{ compounds } & \multirow{2}{*}{$\begin{array}{c}\text { MW } \\
(\mathrm{g} / \mathrm{mol})\end{array}$} & \multicolumn{5}{|c|}{ A2780cis } & \multicolumn{5}{|c|}{ MDR } \\
\hline & & $\begin{array}{c}\mathrm{IC}_{50} \\
(\mu \mathrm{g} / \mathrm{ml})\end{array}$ & $\begin{array}{c}\text { conc. } \\
(\mu \mathrm{g} / \mathrm{ml})\end{array}$ & $\begin{array}{l}\text { steroid conc. } \\
(\mu \mathrm{g} / \mathrm{ml})\end{array}$ & FAR & FIX & $\begin{array}{c}\mathrm{IC}_{50} \\
(\mu \mathrm{g} / \mathrm{ml})\end{array}$ & $\begin{array}{c}\text { conc. } \\
(\mu \mathrm{g} / \mathrm{ml})\end{array}$ & $\begin{array}{l}\text { steroid conc. } \\
(\mu \mathrm{g} / \mathrm{ml})\end{array}$ & FAR & FIX \\
\hline $\mathrm{Cu}\left(\mathrm{ClO}_{4}\right)_{2} \cdot \mathrm{H}_{2} \mathrm{O}$ & 370.54 & 4.22 & 48.99 & - & $1.28 \bullet$ & 1.76 & 3.56 & 48.99 & - & 1.19 & 1.76 \\
\hline $\mathrm{PtClO}_{4}$ & 336.90 & $>50.00$ & 33.61 & - & 0.76 & not calc. & $>50.00$ & 33.61 & - & 1.11 & 2.95 \\
\hline \multirow[t]{3}{*}{4} & \multirow[t]{3}{*}{314.28} & $>50.00$ & 40.00 & 40.00 & 0.81 & 1.43 & $>50.00$ & 40.00 & 40.00 & 1.59 & 1.81 \\
\hline & & \multirow[b]{2}{*}{-} & \multirow[b]{2}{*}{-} & \multirow[b]{2}{*}{-} & \multirow[b]{2}{*}{ - } & $+\mathrm{Cu}: 1.67$ & \multirow[b]{2}{*}{-} & \multirow[b]{2}{*}{-} & \multirow[b]{2}{*}{-} & \multirow[b]{2}{*}{-} & $+\mathrm{Cu}: 1.66$ \\
\hline & & & & & & +Pt: 2.18 & & & & & $+\mathrm{Pt}: 1.26$ \\
\hline $4 \mathrm{C}$ & 684.83 & 29.95 & 84.99 & 39.00 & 0.42 & 2.25 & 6.29 & 84.99 & 39.00 & $27.99 \bullet$ & 1.77 \\
\hline $4 P$ & 651.18 & $>50.00$ & 74.56 & 35.99 & $1.12 \bullet$ & not calc. & 19.79 & 74.56 & 35.99 & $24.57 \bullet$ & 2.38 \\
\hline \multirow[t]{3}{*}{5} & \multirow{3}{*}{411.48} & $>50.00$ & 40.00 & 40.00 & $1.84 \bullet$ & 1.75 & 25.87 & 40.00 & 40.00 & $7.41 \bullet$ & 1.75 \\
\hline & & \multirow{2}{*}{-} & \multirow[b]{2}{*}{ - } & \multirow{2}{*}{-} & \multirow[b]{2}{*}{ - } & $+\mathrm{Cu}: 1.97$ & \multirow{2}{*}{-} & \multirow{2}{*}{-} & \multirow{2}{*}{-} & \multirow{2}{*}{-} & $+\mathrm{Cu}: 1.89$ \\
\hline & & & & & & +Pt: 1.60 & & & & & +Pt: 2.59 \\
\hline $5 \mathrm{C}$ & 782.02 & 8.04 & 81.72 & 42.99 & 0.70 & 1.98 & 5.70 & 81.72 & 42.99 & $105.24 \bullet$ & 2.35 \\
\hline $5 P$ & 748.37 & $>50.00$ & 77.31 & 42.51 & 0.42 & 2.21 & 16.98 & 77.31 & 42.51 & $85.16 \bullet$ & 1.46 \\
\hline \multirow[t]{3}{*}{25} & \multirow[t]{3}{*}{340.50} & 14.81 & 40.00 & 40.00 & $3.40 \bullet$ & 1.35 & $>50.00$ & 40.00 & 40.00 & $92.82 \bullet$ & $0.47 \bullet ?$ \\
\hline & & \multirow{2}{*}{-} & \multirow{2}{*}{ - } & \multirow{2}{*}{-} & \multirow{2}{*}{-} & $+\mathrm{Cu}: 2.24$ & \multirow{2}{*}{-} & \multirow{2}{*}{-} & \multirow{2}{*}{-} & \multirow{2}{*}{-} & $+\mathrm{Cu}: 0.63$ \\
\hline & & & & & & +Pt: 1.41 & & & & & +Pt: 1.13 \\
\hline $25 C$ & 711.04 & 8.54 & 83.19 & 39.84 & $1.38 \bullet$ & 2.62 & 19.85 & 83.19 & 39.84 & $85.34 \bullet$ & 1.81 \\
\hline 25P & 677.39 & 24.95 & 83.59 & 42.02 & 1.08 & 0.72 & 28.54 & 83.59 & 42.02 & $63.77 \bullet$ & 2.07 \\
\hline
\end{tabular}

MW: molar weight. FAR: fluorescence activity ratio. The most active compounds in flow cytometric experiments with FAR values above 1.49 in A2780cis cells and above 5.0 in MDR cells are identified by solid circles $(\bullet)$. Compounds $\mathbf{4 C}, \mathbf{5 C}$ and $\mathbf{2 5 C}$ represent the compounds in complex with $\mathbf{C u}(\mathbf{C l O})_{2} \cdot \mathbf{H} \mathbf{H}_{\mathbf{2}}(\mathrm{Cu})$. Compounds $\mathbf{4} \mathbf{P}, \mathbf{5 P}$ and 25P represent the compounds in complex with $\mathbf{P t C l O}_{4}(\mathrm{Pt})$. The column 'steroid conc. $(\mu \mathrm{g} / \mathrm{ml})$ ' represents the concentration (conc.) of steroids without platinum and copper derived from the steroid-platinum and -copper complexes. In the combination experiments the highest conc. of all compounds was 8 times higher than the $\mathrm{IC}_{50}$ values, or the final conc. was $50 \mu \mathrm{g} / \mathrm{ml}$ when the $\mathrm{IC}_{50}$ was not available to calculate. The anticancer agents were applied at $8 \mu \mathrm{g} / \mathrm{ml}$ (doxorubicin) and $20 \mu \mathrm{g} / \mathrm{ml}$ (cisplatin) for MDR and A7280cis cells, respectively. FIX: fractional inhibitory index: FIX $<0.5$ indicates synergism $(\bullet), 0.5-3.99$ indicates no interaction/additive effect, $4<$ FIX indicates antagonism. In order to determine the differences between the complexes and the drugs applied alone and in combination with anticancer agent doxorubicin or cisplatin, steroid + copper/platinum + chemotherapeutic agent combinations were also evaluated. 
Hydantoin derivatives (II). Thirty hydantoin derivatives (SZ-2, SZ-7, LL-9, BS-1, JH-63, MN-3, TD-7k, GG-5k, P3, P7, P10, P11, RW-15b, AD-26, RW-13, AD-29, KF-2, PDPH3, Mor-1, KK-XV, Thioam-1, JHF-1, JHC-2, JHP-1, Fur-2, GL-1, GL-7, GL-14, GL-16, GL-18) were examined in MDR cells to determine their 50\% growth inhibitory concentrations. The $\mathrm{IC}_{50}$ values varied within a wide range of concentration $(3-450 \mu \mathrm{g} / \mathrm{ml})$. Non-toxic compounds with $\mathrm{IC}_{50}$ values under $100 \mu \mathrm{g} / \mathrm{ml}$ were selected from the 30 hydantoin derivatives (Table IV).

Table IV. The effects of hydantoin derivatives on cell proliferation $\left(\mathrm{IC}_{50}\right)$ and drug resistance (FAR) in MDR cells.

\begin{tabular}{|c|c|c|c|}
\hline compound & $\mathrm{IC}_{50}(\mu \mathrm{g} / \mathrm{ml})$ & $\begin{array}{c}\text { conc. } \\
(\mu \mathrm{g} / \mathrm{ml})\end{array}$ & FAR \\
\hline verapamil & - & 10 & 13.19 \\
\hline \multirow{2}{*}{ SZ-7 } & \multirow{2}{*}{4.54} & 4 & 44.12 \\
\hline & & 40 & 55.98 \\
\hline \multirow{2}{*}{ BS-1 } & \multirow{2}{*}{15.21} & 4 & 77.68 \\
\hline & & 40 & 174.35 \\
\hline \multirow{2}{*}{ JH-63 } & \multirow{2}{*}{15.24} & 4 & 57.05 \\
\hline & & 40 & 107.62 \\
\hline \multirow{2}{*}{ MN-3 } & \multirow{2}{*}{10.55} & 4 & 59.95 \\
\hline & & 40 & 196.42 \\
\hline \multirow{2}{*}{ AD-26 } & \multirow{2}{*}{33.19} & 4 & 28.12 \\
\hline & & 40 & 144.86 \\
\hline \multirow{2}{*}{ AD-29 } & \multirow{2}{*}{39.42} & 4 & 8.65 \\
\hline & & 40 & 180.77 \\
\hline \multirow{2}{*}{ KF-2 } & \multirow{2}{*}{71.99} & 4 & 7.63 \\
\hline & & 40 & 57.38 \\
\hline \multirow{2}{*}{ RW-15b } & \multirow{2}{*}{53.42} & 4 & 1.68 \\
\hline & & 40 & 32.69 \\
\hline \multirow{2}{*}{ RW-13 } & \multirow{2}{*}{11.95} & 4 & 8.56 \\
\hline & & 40 & 25.21 \\
\hline \multirow{2}{*}{ LL-9 } & \multirow{2}{*}{54.19} & 4 & 2.00 \\
\hline & & 40 & 23.42 \\
\hline \multirow{2}{*}{ P-3 } & \multirow{2}{*}{19.33} & 4 & 1.16 \\
\hline & & 40 & 12.13 \\
\hline \multirow{2}{*}{ Thioam-1 } & \multirow{2}{*}{5.272} & 4 & 1.28 \\
\hline & & 40 & 9.49 \\
\hline DMSO & $1.09 \%$ & $4 \%$ & 0.77 \\
\hline
\end{tabular}

The results are from one representative flow cytometric experiment in which $1 \times 10^{4}$ cells were investigated. Conc.: final concentration. FAR: fluorescence activity ratio. Positive control verapamil and solvent control DMSO were applied in the FACS experiment. 
Steroidal alkaloids of Veratrum and Peganum species (III, IV). Nine alkaloids (A1-9) isolated from $V$. lobelianum, $V$. nigrum and $P$. nigelastrum were evaluated for their antiproliferative effects in MDR cells. Their $\mathrm{IC}_{50}$ values were found to be between 20.76 and $26.07 \mu \mathrm{g} / \mathrm{ml}$ for compounds A1-3, A5 and A6 (Table V).

Table V. The effect of alkaloids (A1-9) on cell proliferation $\left(\mathrm{IC}_{50}\right)$ and drug resistance (FAR) in MDR cells.

\begin{tabular}{|c|c|c|c|}
\hline compounds & $\begin{array}{c}\mathrm{IC}_{50} \\
(\mu \mathrm{g} / \mathrm{ml})\end{array}$ & $\begin{array}{l}\text { conc. } \\
(\mu \mathrm{g} / \mathrm{ml})\end{array}$ & FAR \\
\hline verapamil & - & 10 & 6.06 \\
\hline \multirow{2}{*}{ A1 } & \multirow[t]{2}{*}{21.76} & 4 & 1.83 \\
\hline & & 40 & 18.76 \\
\hline \multirow{2}{*}{ A2 } & \multirow[t]{2}{*}{26.07} & 4 & 3.95 \\
\hline & & 40 & 87.00 \\
\hline \multirow{2}{*}{$\mathbf{A 3}$} & \multirow[t]{2}{*}{24.86} & 4 & 2.16 \\
\hline & & 40 & 13.06 \\
\hline \multirow{2}{*}{ A4 } & \multirow[t]{2}{*}{$>50.00$} & 4 & 1.01 \\
\hline & & 40 & 2.35 \\
\hline \multirow{2}{*}{ A5 } & \multirow[t]{2}{*}{22.69} & 4 & 26.81 \\
\hline & & 40 & 93.26 \\
\hline \multirow{2}{*}{ A6 } & \multirow[t]{2}{*}{20.76} & 4 & 33.09 \\
\hline & & 40 & 88.81 \\
\hline \multirow{2}{*}{ A7 } & \multirow[t]{2}{*}{$>50.00$} & 4 & 1.23 \\
\hline & & 40 & 1.38 \\
\hline \multirow{2}{*}{ A8 } & \multirow[t]{2}{*}{$>50.00$} & 4 & 0.96 \\
\hline & & 40 & 1.79 \\
\hline \multirow{2}{*}{ A9 } & \multirow[t]{2}{*}{$>50.00$} & 4 & 1.07 \\
\hline & & 40 & 1.57 \\
\hline DMSO & $1.22 \%$ & $4 \%$ & 1.23 \\
\hline
\end{tabular}

The results are from one representative flow cytometric experiment in which $1 \times 10^{4}$ cells were investigated. Conc.: final concentration. FAR: fluorescence activity ratio. Positive control verapamil and solvent control DMSO were applied in the FACS experiment.

Saponins and phenolic components of Tribulus terrestris and Smilax excelsa (V). Six pure saponins $(\mathbf{S 1 - 4}, \mathbf{8}, \mathbf{9})$, three saponin isomers in a mixture (S5-7) and 2 phenolic components (S10, S11) isolated from the saponin fractions of T. terrestris and S. excelsa were evaluated for their antiproliferative activity in MDR cells, and the $\mathrm{IC}_{50}$ values were found to be between 12.64 and $20.62 \mu \mathrm{g} / \mathrm{ml}$ (detailed data not presented). 


\subsection{Effects of selected compounds on drug resistance in A2780cis and MDR cells.}

\section{Semisubstituted steroids and selected platinum and copper coordination complexes (I).}

In A2780cis cells, seven compounds $(\mathbf{2}, \mathbf{5}, \mathbf{6}, \mathbf{1 2}, \mathbf{2 2}, \mathbf{2 5}, \mathbf{2 7})$ were found to be effective as potent resistance inhibitors resulting in FAR values above 1.5 at $40 \mu \mathrm{g} / \mathrm{ml}$ final concentration. This means that these compounds promoted at least a $50 \%$ increase in the retention of R123 in comparison to the untreated cells. A few compounds $(\mathbf{1 1}, \mathbf{1 3}, \mathbf{1 5}, \mathbf{2 3}, \mathbf{2 4}$, 33) had moderate effects in A2780cis cells with FAR values between 1.1 and 1.5 (Table II, page 26).

In MDR cells, the majority of the semisubstituted steroids resulted in low (e.g. 1, 3, 4, 9) or moderate (e.g. 3, 8) accumulation of R123 when the samples were applied at $4 \mu \mathrm{g} / \mathrm{ml}$ (data not shown), but more than half of these compounds $(2,5-7,10-12,17-19,21-25,27,29$, 30, 32-35) were able to reverse multidrug resistance of MDR cells at $40 \mu \mathrm{g} / \mathrm{ml}$ final concentration resulting in FAR values above 5.0 (Table II, page 26). This means that the accumulation of R123 was at least 5 times greater than that by the untreated control cells.

Three compounds $(\mathbf{4}, \mathbf{5}, \mathbf{2 5})$ were selected for the purpose of examining their modulating effect on resistance in complex with copper(II)-perchlorate $(\mathbf{4 C}, \mathbf{5 C}, \mathbf{2 5 C})$ and platinum(IV)-chloride (4P, 5P, 2P) (Table III, page 27). In A2780cis cells, the steroidplatinum or -copper complexes were not found to be more effective inhibitors of cisplatin resistance than non-complexed steroids. The effect of platinum is questionable since it increased the resistance when applied alone $(\mathrm{FAR}=0.76)$, but slightly decreased the resistance in complex with compound $\mathbf{4}(\mathrm{FAR}$ of $\mathbf{4 P}=1.12)$.

Both copper and platinum complexes were effective resistance inhibitors in MDR cells. Interestingly, 4P, 4C and 5P, 5C steroid-complexes were more effective inhibitors with higher FAR values than the steroids alone, but this statement is not valid for $\mathbf{2 5 P}$ and $\mathbf{2 5 C}$. However, compound $\mathbf{2 5}$ was found to be the most effective inhibitor of resistance in MDR cells with its FAR value of 92.82 at a concentration of $40 \mu \mathrm{g} / \mathrm{ml}$, its complexes (25P and 25C) were found to be less effective resistance inhibitors.

Hydantoin derivatives (II). Out of the thirty hydantoin derivatives, the following non-toxic compounds with $\mathrm{IC}_{50}$ under $100 \mu \mathrm{g} / \mathrm{ml}$ were examined in the $\mathrm{R} 123$ excluding short-term experiment in MDR cells: SZ-7, BS-1, JH-63, MN-3, AD-26, AD-29, KF-2, RW-15b, RW13, LL-9, P3 and Thioam-1, SZ-2, GG-5k, PDPH-3 and KK-XV. Compounds SZ-7, BS-1, 
JH-63, MN-3, AD-26, AD-29, KF-2, RW-15b, RW-13, LL-9, P3 and Thioam-1 significantly increased the retention of rhodamine 123 (Table IV, page 28). Compound BS-1 was the most potent inhibitor (FAR $=77.68)$, it was found to be more than 77 times active at a relatively low concentration of $4 \mu \mathrm{g} / \mathrm{ml}$ in the accumulation of R123 compared to the untreated control. Furthermore, this compound was found to be effective even at very low 0.4 $\mu \mathrm{g} / \mathrm{ml}$ concentration with FAR value of 46.71 (data not presented).

Steroidal alkaloids of Veratrum and Peganum species (III, IV). In the R123 accumulation assay, A1-A3, A5, A6 of the nine alkaloids were found to be better inhibitors of resistance in MDR cells than verapamil with FAR values above 6 at $40 \mu \mathrm{g} / \mathrm{ml}$ concentration. Two alkaloids (A5, A6) were found to be active even at a relatively low concentration of $4 \mu \mathrm{g} / \mathrm{ml}$ (Table $\mathbf{V}$, page 29).

Saponins and phenolic components of Tribulus terrestris and Smilax excelsa (V). In the R123 accumulation assay, all of the Six pure saponins $(\mathbf{S 1 - 4 , 8}, \mathbf{9})$, three saponin isomers in a mixture (S5-7) and 2 phenolic components $(\mathbf{S 1 0}, \mathbf{S 1 1})$ were found to be only moderate MDR inhibitors in MDR cells, since their FAR values were below 7.0 when applied at $40 \mu \mathrm{g} / \mathrm{ml}$ final concentration (detailed data not shown).

2.3. Effects of selected compounds in combination with cisplatin or doxorubicin, in A2780cis or MDR cells, respectively.

Semisubstituted steroids and selected platinum and copper coordination complexes (I).

Selected compounds were evaluated in a checkerboard assay in the presence of the anticancer drug doxorubicin or cisplatin in A2780cis and MDR cell lines, respectively. In A2780cis cell line, no synergistic interaction between cisplatin and selected compounds $(\mathbf{2}, \mathbf{4}, \mathbf{5}, \mathbf{1 2}, \mathbf{1 5}, \mathbf{2 2}$, 25) was found since all of the fractional inhibitory index (FIX) values were found to be between 1 and 2 (data not shown). In MDR cell line, compound 11 was in synergistic interaction with doxorubicin (FIX $=0.45$ ); and the effect of compound 25 in combination with doxorubicin was found to be on the boarder of synergism/additive effect (FIX $=0.47$ ) (Table III, page 27). The other selected compounds $(4,5,16,20,22,33)$ unambiguously were not in synergistic or antagonistic interaction with doxorubicin, all of the FIX values were found to be between 1 and 2 (detailed values not shown).

Furthermore, three compounds $(4,5,25)$ were selected to the compare their effects with their copper (4C, 5C, 25C) or platinum (4P, 5P, 2P) on doxorubicin and cisplatin resistance 
in both cell lines. All of the copper and platinum complexes were found to have only additive effects in the combination experiments with doxorubicin in MDR cells or with cisplatin in A2780cis cells (Table III, page 27).

Hydantoin derivatives (II). Nine compounds (AD-26, AD-29, RW-13, KF-2, BS-1, MN-3, RW-15b, JH-63 and SZ-7) with high FAR values were chosen to determine their interaction with doxorubicin, and out of these, most of the compounds except for SZ-7, showed synergistic interaction with doxorubicin in MDR cells represented by FIX values under 0.5. (Table VI).

Table VI. Interaction between selected hydantoin derivatives and doxorubicin in MDR cells.

\begin{tabular}{l|c}
\hline compounds & FIX values \\
\hline SZ-7 & 1.25 \\
\hline BS-1 & $0.22 \bullet$ \\
\hline JH-63 & $0.49 \bullet$ \\
\hline MN-3 & $0.31 \bullet$ \\
\hline AD-26 & $0.03 \bullet$ \\
\hline AD-29 & $0.08 \bullet$ \\
\hline KF-2 & $0.18 \bullet$ \\
\hline RW-15b & $0.24 \bullet$ \\
\hline RW-13 & $0.16 \bullet$ \\
\hline
\end{tabular}

FIX: fractional inhibitory index: $<0.5$ indicates synergism (solid circles: $\bullet$ ),

0.5-3.99 indicates no interaction/additive effect, $4<$ FIX indicates antagonism.

Steroidal alkaloids of Veratrum and Peganum species (III, IV). The most effective compounds at $4 \mu \mathrm{g} / \mathrm{ml}$ concentration in the MDR reversal experiment, veralosinine (A5) and veranigrine (A6) had synergistic interaction with doxorubicin in MDR cells with FIX values of 0.11 and 0.25 , respectively.

Saponins and phenolic components of Tribulus terrestris and Smilax excelsa (V). The compounds were tested in combination and only one compound, methylprototribestin (S2) with FIX value of 0.49 was found to act in a synergistic manner with the anticancer agent doxorubicin in MDR cells. 


\subsection{Effects of selected steroid-copper and -platinum complexes on apoptosis induction in}

\section{A2780cis and MDR cells.}

None of the tested compounds induced apoptosis either in A2780cis or in MDR cells. However, a non-significant increase of the percentage of apoptotic population was observed when evaluated against A2780cis cells, but the higher dose of compounds $\mathbf{5}$ and $\mathbf{5 C}$ only resulted in increased non-apoptotic dead cell population (Figure 10, Table VII and VIII, pages 34-35).
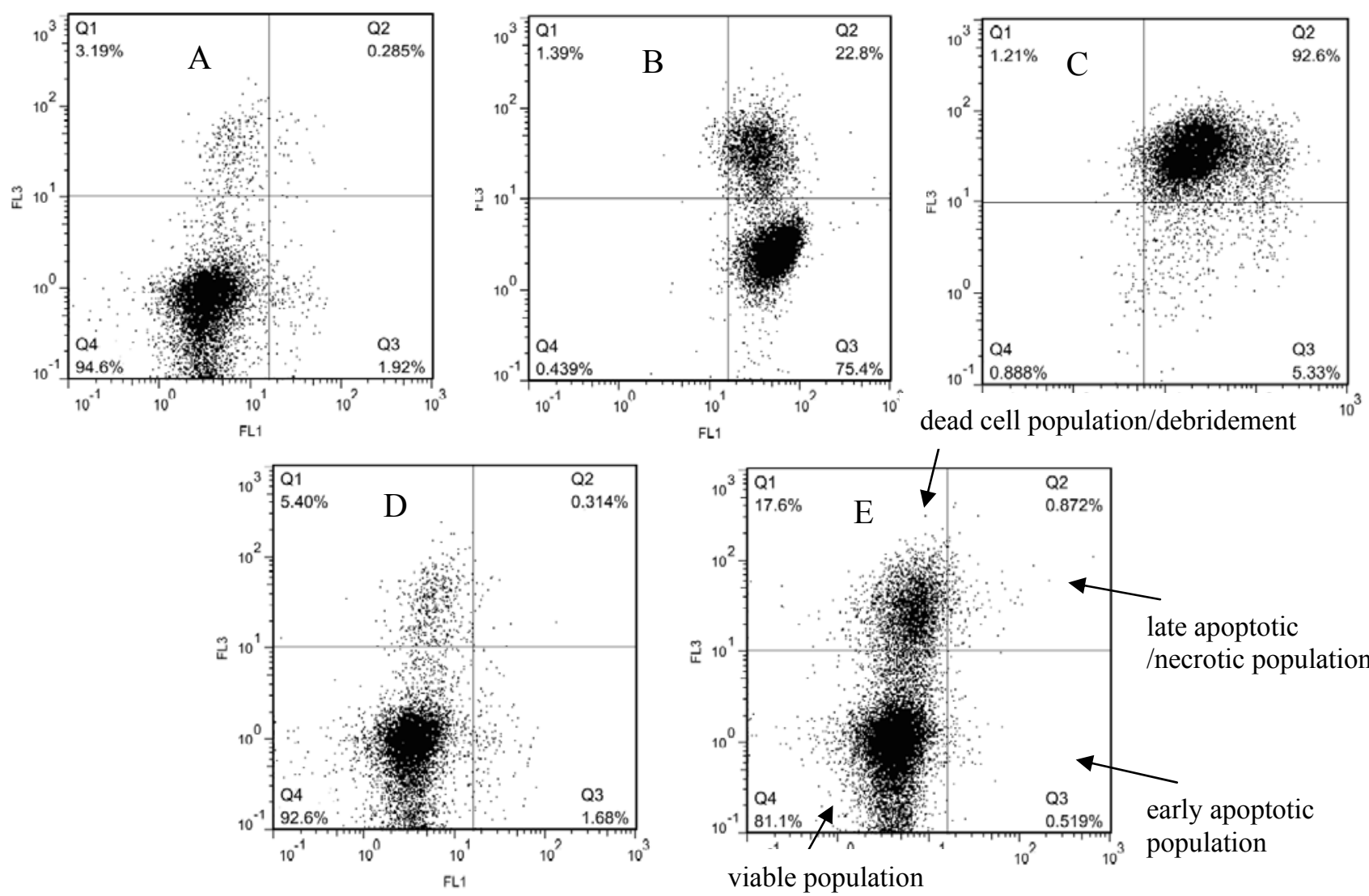

Figure 10. Apoptosis induction in A2780cis ovarian cancer cells. Annexin V-FITC was detected in FL1 channel, propidium iodide (PI) was detected in FL3 channel by flow cytometry. A: negative control, stained with Annexin V-FITC and PI (early apoptotic 1.92\%; late apoptotic/necrotic: $0.285 \%$, dead: $3.19 \%$ ). B: control of apoptosis, treated with M627 (12H-benzo(a)phenothiazine) at a final conc. of $50 \mu \mathrm{g} / \mathrm{ml}$ (early apoptotic: $75.4 \%$; late apoptotic/necrotic: $22.8 \%$; dead: $1.39 \%$ ). C: control of necrosis, treated with $2 \%$ paraformaldehide (PFA) (late apoptotic/necrotic: 92.6\%). D: DMSO control, final conc. of 2\%. E: compound 25 increased the amount of dead cell population $(17.6 \%)$ but not affected early apoptosis $(0.519 \%)$ or necrosis $(0.872 \%)$. The compounds tested in the experiment (Table IX.) did not found to be apoptosis inducers. Some of the compounds like 25P increased the amount of necrotic cell population $(\mathbf{E})$. 
Table VII/ a and b. Effects of selected semisubstituted steroids and their copper and platinum complexes on apoptosis induction in A2780cis ovarian cancer cells.

Table VII/a.

\begin{tabular}{|c|c|c|c|c|}
\hline \multirow[b]{2}{*}{ compounds } & \multirow{2}{*}{$\begin{array}{l}\text { conc. } \\
(\mu \mathrm{g} / \mathrm{ml})\end{array}$} & \multicolumn{3}{|c|}{ gated events \% } \\
\hline & & $\begin{array}{l}\text { early apoptosis } \\
\% \\
\end{array}$ & $\begin{array}{l}\text { late apoptosis } \\
\text { and necrosis \% }\end{array}$ & $\begin{array}{l}\text { dead cells and } \\
\text { debridement \% }\end{array}$ \\
\hline A-I- & - & 0.07 & 0.00 & 0.00 \\
\hline $\mathbf{A}+\mathbf{I}+$ & - & 9.92 & 2.08 & 2.94 \\
\hline M627 & 50.00 & 77.30 & 21.10 & 0.98 \\
\hline \multirow{2}{*}{$\mathrm{PtClO}_{4}$} & 44.80 & 3.70 & 1.41 & 5.44 \\
\hline & 8.96 & 6.66 & 1.82 & 4.20 \\
\hline \multirow{2}{*}{$\mathrm{Cu}\left(\mathrm{ClO}_{4}\right)_{2} \cdot 6 \mathrm{H}_{2} \mathrm{O}$} & 4.90 & 5.68 & 1.62 & 4.49 \\
\hline & 0.98 & 6.37 & 1.45 & 3.31 \\
\hline \multirow{2}{*}{4} & 50.00 & 8.61 & 1.73 & 3.17 \\
\hline & 10.00 & 8.02 & 1.39 & 3.13 \\
\hline \multirow{2}{*}{$4 \mathrm{Pt}$} & 49.73 & 9.53 & 5.66 & 6.24 \\
\hline & 9.95 & 6.71 & 1.91 & 4.21 \\
\hline \multirow{2}{*}{5} & 50.00 & 13.40 & 2.34 & 4.39 \\
\hline & 10.00 & 11.30 & 2.40 & 3.63 \\
\hline \multirow{2}{*}{$5 P$} & 51.53 & 6.93 & 5.93 & 8.63 \\
\hline & 10.31 & 8.67 & 2.71 & 4.43 \\
\hline \multirow{2}{*}{$5 \mathrm{C}$} & 8.18 & 11.10 & 1.97 & 2.33 \\
\hline & 1.64 & 11.20 & 1.70 & 2.75 \\
\hline DMSO & $1 \%$ & 7.77 & 1.56 & 3.04 \\
\hline
\end{tabular}

Table VII/b.

\begin{tabular}{|c|c|c|c|c|}
\hline \multirow[b]{2}{*}{ compounds } & \multirow[b]{2}{*}{$\begin{array}{l}\text { conc. } \\
(\mu \mathrm{g} / \mathrm{ml})\end{array}$} & \multicolumn{3}{|c|}{ gated events \% } \\
\hline & & \begin{tabular}{|l} 
early apoptosis \\
$\%$
\end{tabular} & $\begin{array}{l}\text { late apoptosis } \\
\text { and necrosis \% } \\
\end{array}$ & $\begin{array}{l}\text { dead cells and } \\
\text { debridement } \%\end{array}$ \\
\hline A- I- & - & 0.09 & 0.01 & 0.00 \\
\hline $\mathbf{A}+\mathbf{I}+$ & - & 1.92 & 0.29 & 3.19 \\
\hline M627 & 50.0 & 75.40 & 22.80 & 1.39 \\
\hline PFA & $2 \%$ & 5.33 & 92.6 & 1.21 \\
\hline \multirow{2}{*}{25} & 50.00 & 2.03 & 0.38 & 6.33 \\
\hline & 10.00 & 1.94 & 0.35 & 3.99 \\
\hline \multirow{2}{*}{$25 P$} & 27.87 & 0.52 & 0.87 & 17.60 \\
\hline & 5.57 & 1.20 & 0.33 & 7.10 \\
\hline \multirow{2}{*}{$25 \mathrm{C}$} & 8.32 & 1.55 & 0.22 & 5.94 \\
\hline & 1.66 & 1.17 & 0.20 & 3.93 \\
\hline \multirow{2}{*}{4} & 50.00 & 1.51 & 0.27 & 6.04 \\
\hline & 10.00 & 1.37 & 0.30 & 6.47 \\
\hline \multirow{2}{*}{$4 C$} & 42.50 & 0.13 & 0.17 & 10.70 \\
\hline & 8.50 & 0.16 & 0.41 & 10.00 \\
\hline \multirow{2}{*}{5} & 200.00 & 0.39 & 0.49 & 7.49 \\
\hline & 50.00 & 1.70 & 0.35 & 10.60 \\
\hline \multirow{2}{*}{$5 \mathrm{C}$} & 81.80 & 0.53 & 0.24 & 10.00 \\
\hline & 8.18 & 1.62 & 0.27 & 6.12 \\
\hline DMSO & $1 \%$ & 7.77 & 1.56 & 3.04 \\
\hline
\end{tabular}

Conc.: concentration. The compounds were tested in $\mathrm{IC}_{50}$ and $\mathrm{IC}_{10}$ concentrations. A-I-: unstained negative control. A+I+: Annexin (A) and propidium-iodide (I) stained control. M627 (12Hbenzo(a)phenothiazine): control of apoptosis. PFA (paraformaldehide): control of necrosis. DMSO: control of solvent. 
Table VIII/ a and b. Effects of selected semisubstituted steroids and their copper and platinum complexes on apoptosis induction in MDR mouse T-lymphoma cells.

Table VIII/a.

\begin{tabular}{|c|c|c|c|c|}
\hline \multirow[b]{2}{*}{ compounds } & \multirow{2}{*}{$\begin{array}{l}\text { conc. } \\
(\mu \mathrm{g} / \mathrm{ml})\end{array}$} & \multicolumn{3}{|c|}{ gated events \% } \\
\hline & & $\begin{array}{l}\text { early apoptosis } \\
\%\end{array}$ & $\begin{array}{l}\text { late apoptosis } \\
\text { and necrosis \% }\end{array}$ & $\begin{array}{l}\text { dead cells and } \\
\text { debridement } \%\end{array}$ \\
\hline A-I- & - & 0.03 & 0.01 & 0.03 \\
\hline $\mathbf{A}+\mathbf{I}+$ & - & 0.74 & 0.74 & 0.74 \\
\hline M627 & 50.00 & 73.18 & 11.36 & 0.93 \\
\hline \multirow{2}{*}{$\mathrm{PtClO}_{4}$} & 33.61 & 0.48 & 0.01 & 0.23 \\
\hline & 3.36 & 1.01 & 0.05 & 0.17 \\
\hline \multirow{2}{*}{$\mathrm{Cu}\left(\mathrm{ClO}_{4}\right)_{2} \cdot 6 \mathrm{H}_{2} \mathrm{O}$} & 48.90 & 0.67 & 0.01 & 0.06 \\
\hline & 4.90 & 0.46 & 0.01 & 0.13 \\
\hline \multirow{2}{*}{5} & 40.00 & 0.31 & 0.01 & 0.13 \\
\hline & 4.00 & 0.55 & 0.03 & 0.20 \\
\hline \multirow{2}{*}{$5 P$} & 77.31 & 0.74 & 0.25 & 2.03 \\
\hline & 7.33 & 0.55 & 0.03 & 0.20 \\
\hline \multirow{2}{*}{$5 C$} & 81.80 & 0.50 & 0.03 & 0.04 \\
\hline & 8.18 & 0.53 & 0.01 & 0.18 \\
\hline \multirow{2}{*}{25} & 40.00 & 0.33 & 0.01 & 0.56 \\
\hline & 4.00 & 0.31 & 0.06 & 1.11 \\
\hline \multirow{2}{*}{ 25P } & 83.59 & 0.94 & 0.19 & 6.67 \\
\hline & 8.36 & 0.58 & 0.09 & 0.75 \\
\hline \multirow{2}{*}{$25 \mathrm{C}$} & 83.19 & 0.49 & 0.02 & 0.80 \\
\hline & 8.32 & 0.25 & 0.01 & 0.68 \\
\hline DMSO & $1 \%$ & 0.39 & 0.03 & 0.29 \\
\hline
\end{tabular}

Table VIII/b

\begin{tabular}{|c|c|c|c|c|}
\hline \multirow[b]{2}{*}{ compounds } & \multirow[b]{2}{*}{$\begin{array}{l}\text { conc. } \\
(\mu \mathrm{g} / \mathrm{ml})\end{array}$} & \multicolumn{3}{|c|}{ gated events \% } \\
\hline & & $\begin{array}{l}\text { early apoptosis } \\
\%\end{array}$ & $\begin{array}{l}\text { late apoptosis } \\
\text { and necrosis \% }\end{array}$ & $\begin{array}{l}\text { dead cells and } \\
\text { debridement } \%\end{array}$ \\
\hline A-I- & 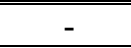 & 0.48 & 0.05 & 0.14 \\
\hline $\mathbf{A}+\mathbf{I}+$ & - & 3.75 & 1.28 & 0.38 \\
\hline M627 & 50.00 & 83.30 & 12.26 & 0.42 \\
\hline \multirow[b]{2}{*}{4} & 40.00 & 3.59 & 1.29 & 0.57 \\
\hline & 4.00 & 6.63 & 2.14 & 0.12 \\
\hline \multirow[b]{2}{*}{ 4P } & 74.56 & 2.53 & 0.80 & 0.69 \\
\hline & 7.46 & 2.52 & 0.62 & 0.59 \\
\hline \multirow[b]{2}{*}{$4 \mathrm{C}$} & 84.99 & 2.83 & 0.85 & 0.31 \\
\hline & 8.50 & 2.29 & 0.74 & 0.74 \\
\hline DMSO & $1 \%$ & 1.79 & 0.63 & 0.79 \\
\hline
\end{tabular}

Conc.: concentration. The compounds were tested in $\mathrm{IC}_{50}$ and $\mathrm{IC}_{10}$ concentrations. A-I-: unstained negative control. A+I+: Annexin (A) and propidium-iodide (I) stained control. M627 (12Hbenzo(a)phenothiazine): control of apoptosis. DMSO: control of solvent. 


\section{SNP analysis to determine their role in cancer}

In our examinations, single nucleotide polymorphisms (SNPs) of $A B C B 1, P 53, B A X$, and $B C L 2$ were studied to find genetic differences between cancer patient and healthy volunteer groups. The patients were divided into two groups: gynecological cancer group (ovarian and cervical cancer, $n=31)$, and a mixed cancer group $(n=57)$. A group of healthy volunteers $(\mathrm{n}=99)$ was applied as control group. The following SNPs were examined: $A B C B 1$ (rs2032582, rs1045642), P53 (rs1042522), BCL2 (rs4645878) and BAX (rs2279115) (172, 173).

The observed genotype frequencies of the SNPs were in agreement with HardyWeinberg equilibrium (HWE) using $\chi^{2}$-square test. In the single-locus analysis, when the $B A X$ AA genotype (SNP nr. rs2279115) was used as the reference group, significant association ( $\chi^{2}$-square test, $\left.P<0.01, \mathrm{OR}=3.561, \mathrm{CI}=95 \%\right)$ was found between the GG and GA variant genotypes and risk of cancer between the control and the mixed cancer group. In this case we tested the sample size (type I error $=0.1$, power $=0.9$ adjusted, calculated with Fisher's exact test, $\mathrm{n}=57$ ) and the power of the sample (type I error $=0.1, \mathrm{n}=57$ adjusted, calculated with Fisher's exact test, power $=0.974)$, both were in the range of acceptance. In the single locus analysis of $A B C B 1$ when the TT genotype was used as the reference group (SNPs nr. rs2032582 and rs1045642), no association was found between the GG/GT or CC/CT genotypes in cancer patient and healthy volunteer groups. Strong linkage disequilibrium was measured between the two SNPs of ABCB1 $\left(\mathrm{r}^{2}=0.114\right)$. In the single locus analysis of P53 when GG genotype was used as the reference group (SNP nr. rs1042522), no significant association was found between CC and CG genotypes, however, a positive trend $(P=0.059)$ with $\mathrm{OR}=1.622(\mathrm{CI}=95 \%)$ was found in the mixed cancer group by using $\chi 2$-square test. In the single locus analysis of BCL2 when the BCL2 AA genotype was used as the reference group (SNP nr. rs4645878), no association was found between the CC and CA genotypes in cancer patient and healthy volunteer groups (Table IX, page 37).

In summary, we could demonstrate the correlation of a certain SNP and cancer in case of BAX SNP nr. rs2279115, but not in the case of the other four genes, however, we evaluated a limited number of patient. Therefore, the power of the sample was not strong enough to verify our null hypothesis (H0) about the connection of these SNPs of ABCB1, BCL2, P53 and cancer. 
Table IX. Results of the PCR-RFLP experiments in which five SNPs of four cancer-related genes (ABCB1, BAX, BCL2, P53) were examined.

\begin{tabular}{|c|c|c|c|c|c|c|c|c|c|c|}
\hline \multirow{3}{*}{ gene } & \multirow{3}{*}{ nt. change } & \multirow{3}{*}{ rs number } & \multirow{3}{*}{ genotype } & \multirow{3}{*}{$\begin{array}{l}\text { controls } \\
(\mathrm{n}=99)\end{array}$} & \multicolumn{6}{|c|}{ cases } \\
\hline & & & & & \multicolumn{3}{|c|}{ gynecological $(\mathrm{n}=31)$} & \multicolumn{3}{|c|}{ mixed group $(\mathrm{n}=57)$} \\
\hline & & & & & frequencies & $P$ value & OR $(95 \% \mathrm{CI})$ & frequencies & $P$ value & OR $(95 \% \mathrm{CI})$ \\
\hline \multirow[t]{8}{*}{$A B C B 1$} & G2677T & rs2032582 & $\mathrm{G} / \mathrm{G}$ & $33(33.67 \%)$ & $13(41.93 \%)$ & & & $17(29.82 \%)$ & & \\
\hline & & & $\mathrm{G} / \mathrm{T}$ & $44(44.9 \%)$ & $11(35.48 \%)$ & & & $31(54.39 \%)$ & & \\
\hline & & & & $21(21.43 \%)$ & $7(22.58 \%)$ & & & $9(15.79 \%)$ & & \\
\hline & & & & $98(100 \%)$ & $31(100 \%)$ & 0.622 & $1.157(\mathrm{~T} \rightarrow \mathrm{G})$ & $57(100 \%)$ & 0.878 & $1.037(\mathrm{~T} \rightarrow \mathrm{G})$ \\
\hline & C3435T & rs 1045642 & $\mathrm{C} / \mathrm{C}$ & $19(19.19 \%)$ & $10(32.26 \%)$ & & & $12(21.05 \%)$ & & \\
\hline & & & $\mathrm{C} / \mathrm{T}$ & $55(55.56 \%)$ & $15(48.39 \%)$ & & & $33(57.9 \%)$ & & \\
\hline & & & $\mathrm{T} / \mathrm{T}$ & $25(25.25 \%)$ & $6(19.35 \%)$ & & & $12(21.05 \%)$ & & \\
\hline & & & & $99(100 \%)$ & $31(100 \%)$ & 0.193 & $1.464(\mathrm{~T} \rightarrow \mathrm{C})$ & $57(100 \%)$ & 0.606 & $1.129(\mathrm{~T} \rightarrow \mathrm{C})$ \\
\hline \multirow[t]{4}{*}{$B A X$} & G-248A & rs2279115 & $\mathrm{G} / \mathrm{G}$ & $41(41.84 \%)$ & $21(67.74 \%)$ & & & $42(75 \%)$ & & \\
\hline & & & G/A & $41(41.84 \%)$ & $4(12.91 \%)$ & & & $12(21.43 \%)$ & & \\
\hline & & & $\mathrm{A} / \mathrm{A}$ & $16(16.32 \%)$ & $6(19.35 \%)$ & & & $2(3.57 \%)$ & & \\
\hline & & & & $98(100 \%)$ & $31(100 \%)$ & 0.099 & $1.706(\mathrm{~A} \rightarrow \mathrm{G})$ & $56(100 \%)$ & $<0.001 *$ & $3.561(\mathrm{~A} \rightarrow \mathrm{G})$ \\
\hline \multirow[t]{4}{*}{ BCL2 } & C-938A & rs 4645878 & $\mathrm{C} / \mathrm{C}$ & $33(33.33 \%)$ & $13(41.94 \%)$ & & & $15(27.27 \%)$ & & \\
\hline & & & $\mathrm{C} / \mathrm{A}$ & $44(44.44 \%)$ & $10(32.26 \%)$ & & & $24(43.64 \%)$ & & \\
\hline & & & $\mathrm{A} / \mathrm{A}$ & $22(22.23 \%)$ & $\underline{8(25.80 \%)}$ & & & $\underline{16(29.09 \%)}$ & & \\
\hline & & & & $99(100 \%)$ & $31(100 \%)$ & 0.728 & $1.108(\mathrm{~A} \rightarrow \mathrm{C})$ & $55(100 \%)$ & 0.276 & $0.771(\mathrm{~A} \rightarrow \mathrm{C})$ \\
\hline \multirow[t]{4}{*}{ P53 } & C119G & rs1042522 & $\mathrm{C} / \mathrm{C}$ & $36(36.36 \%)$ & $13(41.94 \%)$ & & & $30(54.55 \%)$ & & \\
\hline & & & $\mathrm{C} / \mathrm{G}$ & $49(49.49 \%)$ & $13(41.94 \%)$ & & & $19(34.55 \%)$ & & \\
\hline & & & $\mathrm{G} / \mathrm{G}$ & $14(14.15 \%)$ & $\underline{5(16.12 \%)}$ & & & $6(10.9 \%)$ & & \\
\hline & & & & $99(100 \%)$ & $31(100 \%)$ & 0.800 & $1.079(\mathrm{G} \rightarrow \mathrm{C})$ & $55(100 \%)$ & 0.059 & $1.622(\mathrm{G} \rightarrow \mathrm{C})$ \\
\hline
\end{tabular}

nt. change - nucleotide base change in the given position (e.g. G2677T means that guanine is changed to thymine at location of 2677); rs number - reference sequence number; OR - odds ratio; $P$ value calculated for $95 \%$ confidence interval $(\mathrm{CI})$, significance level $<0.01$; * represents significant differences in allele distribution. Significant association was found in BAX SNP between the GG and GA variant genotypes and risk of cancer between the control and the mixed cancer group $(P<0.01, \mathrm{OR}=3.561, \mathrm{CI}=95 \%)$. 


\section{DISCUSSION}

The emergence of drug or multidrug resistance (MDR) in cancer cells leads to the ineffectiveness of chemotherapy. Both in leukemia and ovarian cancer, resistance against chemotherapeutic agents is a multifactorial mechanism, but overexpression of the ABCB1 membrane transporter is amongst the well-known cause of $\operatorname{MDR}(28,29)$.

To overcome MDR induced by the expression of human ABCB1, various compounds of synthetic and natural origin have been studied at the Department of Medical Microbiology and Immunobiology for more than 30 years in different cancer cell lines (lymphoma, lung, colon, breast, etc.). Several compounds have been found as promising resistance modifiers, for example, flavonoids and phenothiazines such as chlorpromazines, stilbenes, di- and triterpenes and carotenoids (60-65). Furthermore, specifically modified compounds have also been investigated, such as metal coordination complexes of tricyclic compounds, since it has been assumed that metals induce some changes in binding features to $\mathrm{ABCB} 1(61,109)$.

Besides the doxorubicin resistance due to the overexpression of ABCB1 in many cancer types, cisplatin resistance is another common problem of cancer chemotherapy (35). A number of studies have demonstrated that copper transporters (CTR1/2 and ATP7A/B) are responsible for transport of cisplatin (71-74). On the other hand, other mechanisms like altered gene expression and mismatch repair might be responsible for cisplatin resistance in certain tumors as well (31).

Drug resistance of cancer may also be due to alterations in gene expression, forasmuch changes in certain regulatory genes can lead to increased or decreased expression levels of proteins important in resistance and survival of cancer cells $(37,38,120-125)$.

The main aim of our study was to evaluate the effects of synthetic and natural compounds on drug resistance in a cisplatin-resistant human ovarian cancer cell line (A2780cis) and in a human ABCB1-transfected doxorubicin-resistant mouse T-lymphoma cell line (MDR). Before the investigation of selected compounds, these cell lines were examined by immunocytochemistry. Furthermore, distributions of certain single nucleotide polymorphisms (SNPs) in cancer-related genes were also investigated to determine their role in cancer. 


\section{Immunocytochemistry}

All cell lines were characterized with monoclonal antibodies (MABs). High level of ABCB1 expression was detected in the membrane of the MDR cells, whereas in the A2780cis, and in the control cell lines A2780 and PAR the expression of ABCB1 was not detected. Aspecific staining of the cytoplasm was shown when using MRP1 specific monoclonal antibody (MAB) in both MDR and A2780cis cell lines. The expression of estrogen or progesterone hormone receptors was undetectable in A2780/cis and PAR/MDR cell lines, but it was shown in MCF7 breast cancer control cell line.

Previously, it has been shown that this A2780cis ovarian cancer cell line does not overexpress CTR1, but it has been also demonstrated that the expression of CTR1 and CTR2 can be modified after treatment by special compounds, and this is also true for the other two transporters, the P-type transporters ATP7A and ATP7B (78). The mechanism of cisplatin resistance in the A2780cis cells is still not fully determined, therefore, further investigation is required; however, the resistance is supposedly due to a multifactorial mechanism including altered transporter expression patterns, mismatch repair and cell-cycle modification (31). We may assume that the effects of our extensively examined steroid-type compounds can be basically different from that of hormone-dependent tumors.

\section{Effects of selected compounds in cancer cells}

In our experiments semisubstituted steroids (I) and their platinum and copper complexes, hydantoin derivatives (II), alkaloids of Veratrum and Peganum species (III, IV), and saponins and phenolic components of Tribulus terrestris and Smilax excelsa (V) were examined.

\subsection{Semisubstituted steroids and selected platinum and copper complexes (I).}

A number of steroid-type molecules have been described previously to prevent drug and multidrug resistance in cancer $(130,131)$. Furthermore, metal complexes remain an important resource for the generation of chemical diversity in the search for novel therapeutic and diagnostic agents, especially in the area of anticancer drug development (111). At present, a number of metal-based compounds are known to have promising antiproliferative effects in a wide range of tumors. Furthermore, newly discovered proteins and enzymes serve as targets of anticancer coordination complex design (114). For instance, the target of tetrahedral Au(I) 
phosphine complexes displays a wide spectrum of anticancer activity in vivo, especially in cisplatin-resistant cell lines (115).

A number of studies have demonstrated that copper transporters CTR1 and CTR2, and the P-type ATPase transporter $\alpha$ and $\beta$ (ATP7AB) are responsible for transport of cisplatin (71-74). Therefore, we tried to combine the advantages of platinum and copper-based coordination complexes and resistance modifier steroid-based compounds in a wish to overcome drug resistance. In our study, thirty-five estrone- and androstane-type compounds (1-35) and copper and platinum complexes of selected compounds were examined in A2780cis and MDR cell lines. Eighteen compounds were effective as proliferation inhibitors with $\mathrm{IC}_{50}$ under $50 \mu \mathrm{g} / \mathrm{ml}$ in A2780cis cells, and fourteen were found to inhibit cell proliferation in MDR cells. Only two compounds (9 and 34) were active in both cell lines.

Then, the compounds were examined as potent resistance inhibitors. Seven of the substituted steroids (compounds 2, 5, 6, 12, 22, 25, 27) were found to be effective in inhibition of resistance in both cell lines. On the basis of the activity of the steroid samples, certain tendencies seem to be present. Both androstane derivatives and estrone ethers can be found among the active and inactive groups of compounds, consequently, the activity does not depend on the structure of the skeleton. Thus, it is rather the nature and arrangement of the functional groups that determine the activity of the compound. Compounds containing a primary amino function with $\mathrm{O}$-acetyl or $\mathrm{N}$-acetyl groups (compounds 9 , 10, 18, 23, 24, 27, $\mathbf{2 9}, \mathbf{3 3}, \mathbf{3 4}$ ) were cytotoxic for both cell types. Very polar compounds containing two or more hydroxyl groups or secondary amino groups were ineffective in our examinations (compounds $1,3,4,11,14,16,17,19-21,26,28,31,32,35)$. But most of the samples, where these groups are arranged on the D-ring of the skeleton and the $\mathrm{O}$ or $\mathrm{N}$ atom of the functional group is at 1,3-position to D-ring was found to be active in both cell types (compounds $\mathbf{2 ,} \mathbf{5}, \mathbf{6 , 1 2}, \mathbf{2 5}$ ). This structural arrangement may serve as a binding moiety on the polar protein-glycan surface of the cells and can result in an effect independent of the structure of the A ring. The distance between $\mathrm{X}$ and Y (300-400 pm) may allow a supramolecular connection on the peptide chain of the cell surface by polar-polar interaction (Figure 11, page 41). Our in vitro experimental data indicate that some of the steroid-type semisynthetic molecules can be regarded as promising structures for rational drug design as resistance inhibitors with a novel mechanism of action. 


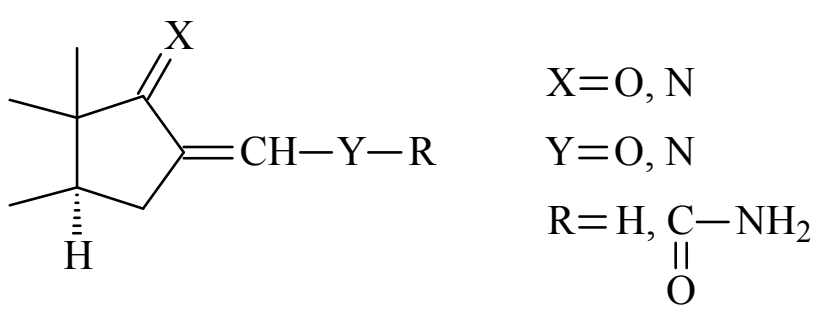

Figure 11. Structure of the most active five semisubstituted steroid-type compounds $(\mathbf{2}, \mathbf{5}$, 6, 12, 25) examined with the MDR reversal assay in both cell lines. Their common feature is the $\mathrm{O}$ or $\mathrm{N}$ atom in 1,3-position to D-ring. The distance between $\mathrm{X}$ and $\mathrm{Y}$ (300-400 pm) may allow a supramolecular connection on the peptide chain of the cell surface by polarpolar interaction.

Then, the interaction between anticancer agents and steroid-derivatives was examined. In A2780cis cell line, we did not find synergistic interaction between cisplatin and any of the steroid-type compounds. $(\mathbf{2}, \mathbf{4}, \mathbf{5}, \mathbf{1 2}, \mathbf{1 5}, \mathbf{2 2}, \mathbf{2 5})$. In MDR cell line, one compound (11) was in synergistic interaction with doxorubicin $(\mathrm{FIX}=0.45)$ and another compound $(\mathbf{2 5})$ was found to be less synergistic $(\mathrm{FIX}=0.47)$.

After the examination of these thirty-five steroids in both cell types, three compounds $(4,5,25)$ were selected to determine their effect in platinum and copper complexes. Copper complexes seem to be better inhibitors of cell proliferation than platinum-steroid complexes in both cell types according to the $\mathrm{IC}_{50}$ values. In A2780cis cells, none of the complexes were found to be better resistance inhibitors than the non-complexed steroids. The effect of platinum is questionable, since it increased the resistance when applied alone (FAR $=0.76)$, but slightly decreased the resistance in complex with compound $\mathbf{4}$ (FAR of $\mathbf{4 P}=1.12$ ). In MDR cells, both platinum and copper complexes were effective resistance inhibitors. Interestingly, 4P, 4C and 5P, 5C steroid-complexes were more effective inhibitors with higher FAR values than the steroids alone, but it is not true for $\mathbf{2 5 P}$ and $\mathbf{2 5 C}$. However, compound 25 was found to be the most effective inhibitor of resistance in MDR cells with its FAR value of 92.82 (final conc. $40 \mu \mathrm{g} / \mathrm{ml}$ ), its complexes 25P and 25C were less effective. In this experiments all compounds were evaluated at ten-fold lower concentrations (data not shown), and it was found that the FAR values were about four-fold lower. This means that these compounds act in a concentration-dependent manner, and at the higher concentration the membrane-embedded ABCB1 transporters might be oversaturated. 
In the apoptosis induction experiments none of the tested compounds induced apoptosis in A2780cis or in MDR cells. However, a non-significant increase of the percentage of apoptotic population was observed when evaluated in A2780cis cells, but the higher dose of compounds $\mathbf{5}$ and 5C only resulted in increased non-apoptotic dead cell population. Most likely these selected compounds at higher concentrations directly alter membrane structure rather than modify apoptotic pathways, thus, inducing necrosis and avoiding apoptosis in these two examined cell lines.

\subsection{Hydantoin derivatives (II).}

Various aspects of the biochemical and pharmacological properties of hydantoin derivatives have been studied, such as fungicidal, herbicidal and anti-inflammatory properties $(141,142)$. The cytotoxic activity of spirohydantoin derivatives has been tested in ovarian and breast cancer cell lines (143). It has been shown that some 1,5-disubstituted hydantoins inhibit epidermal growth factor receptor (EGFR), autophosphorylation and proliferation of human A549 cells that overexpress EGFR (144). Recent studies have shown that some diversely substituted diazaspirohydantoins have an antiproliferative effect against MCF-7 breast carcinoma, HepG-2 hepatocellular carcinoma, HeLa cervix carcinoma and HT-29 colon carcinoma cell lines (145). Furthermore, it has been shown that two spirohydantoin derivatives inhibit cell growth and induce apoptosis in leukemia and colon cancer cells (64, 146). The result of a recent study has provided evidence to support the concept that introducing accessory metal centers is a viable strategy for augmentation of the cytotoxic activity of platinum drugs (147). Further data about the in vitro cytotoxicity of new platinum(II) complexes with hydantoin ligands have demonstrated that 5-methyl-5phenylhydantoin, as well as the previously synthesized spirohydantoin compounds cyclopentanespirohydantoin and cyclohexanespirohydantoin, exert concentration-dependent cytotoxic activity in a panel of tumor cell lines, although less pronounced than that of the reference drug cisplatin (148).

In our experiments, thirty hydantoin derivatives were evaluated by the antiproliferative assay, then they were examined for their drug resistance reversal activity in MDR cells by R123 accumulation assay, finally, the mode of interactions between the resistance modifier doxorubicin and selected compounds were determined. The $\mathrm{IC}_{50}$ values varied widely between 3 and $450 \mu \mathrm{g} / \mathrm{ml}$. Non-toxic compounds with $\mathrm{IC}_{50}$ values under $100 \mu \mathrm{g} / \mathrm{ml}$ were 
selected from the 30 hydantoin derivatives (AD-26, AD-29, RW-13, KF-2, BS-1, MN-3, RW-15b, JH-63, SZ-7, LL-9, P-3 and Thioam-1) to determine their effect on resistance reversal. Compound BS-1 was the most potent inhibitor of resistance (FAR $=77.68)$, this compound was active with FAR value of 46.71 at very low $0.4 \mu \mathrm{g} / \mathrm{ml}$ concentration. Nine compounds (AD-26, AD-29, RW-13, KF-2, BS-1, MN-3, RW-15b, JH-63 and SZ-7) with high FAR values were chosen to determine their interaction with doxorubicin, out of these, most of the compounds except for SZ-7 showed synergistic interaction in MDR cells represented by FAR values under 0.5 .

All of the most effective compounds contained aromatic substituents as well as some tertiary amine fragments.

\subsection{Steroidal alkaloids of Veratrum and Peganum species (III, IV).}

The alkaloids have extensive pharmacological actions including anticancer, anti-Alzheimer's disease, anti-diabetes, antimicrobial and anti-inflammatory activities (149, 150). Vinca alkaloids are most famous for being anticancer agents, since they are well-known substrates of the ABCB1 transporter. Furthermore, Lee et al. demonstrated that the cytotoxic effects of vinca alkaloids as well as those of podophyllotoxin against certain human tumor cells are antagonized by cisplatin (150).

Therefore, newly extracted alkaloids were considered to be promising as possible ABCB1-inhibitors. The present study was undertaken to access the inhibition of MDR of cancer cells by steroidal alkaloids (A1-9) isolated from Veratrum lobelianum, V. nigrum and Peganum nigelastrum. Plants from genus Veratrum and genus Peganum were traditionally used as medicinal substances in Mongolia for a long time $(152,153)$. The main chemical ingredients in $V$. lobelianum, $V$. nigrum and $P$. nigelastrum species are steroidal and indoletype alkaloids. Some steroidal alkaloids moderately inhibited the cell proliferation of MDR cells. The $\mathrm{IC}_{50}$ values were found to be between 20.76 and $26.07 \mu \mathrm{g} / \mathrm{ml}$ for compounds A1-3, A5 and A6. The MDR inhibitory effects of the alkaloids were examined on MDR cells and the most active compounds were veralosinine (A5), veranigrine (A6) and verabenzoamine (A2). The most effective compounds at $4 \mu \mathrm{g} / \mathrm{ml}$ concentration in the MDR reversal experiment, veralosinine (A5) and veranigrine (A6) had synergistic interaction with doxorubicin. 
The mechanism by which these steroidal alkaloids inhibit ABCB1 activity is currently unknown. However, structurally these alkaloids are small lipophilic molecules with planar polycyclic skeleton and tertiary nitrogen atom and are likely to be able to enter cells by passive diffusion (177). Although, it is difficult to find structural features that are common to a large number of chemosensitisers, it has been suggested that resistance modifier agents are hydrophobic, contain two or more planar aromatic rings and tertiary nitrogen (178). The structure of steroidal alkaloids fits this profile.

\subsection{Saponins and phenolic components of Tribulus terrestris and Smilax excelsa (V).}

Saponins are generally found in the roots, flowers and seeds of the higher plants and have long been used against various diseases, to enhance natural resistance $(154,155)$. In a recent study it was found that tubeimoside I, a triterpenoid saponin extracted from Bolbostemma paniculatum, sensitizes to cisplatin in cisplatin-resistant A2780cis human ovarian cancer cells $(179,180)$.

We examined saponins and phenolic components (S1-S11) isolated from T. terrestris and S. excelsa in order to find new resistance modifiers (156-163). All of these compounds were found to be moderate inhibitors of proliferation and MDR in MDR cells. Furthermore, in the combination experiment, it was found that one of these eleven saponins, methyloprototribestin (S2) can act in a synergistic manner with doxorubicin; however the FIX value of 0.49 is on the boarder of additive effect/synergism.

When evaluating the structure-activity relationship, the activity of these saponins appears to correlate the position of sulphur-containing substituents; this may refer to the role of charge transfer complex formation while binding of these compounds to ABCB1. Since it has already been demonstrated that saponins can sensitize A2780cis cancer cell to cisplatin, these new compounds isolated from $T$. terrestris and $S$. excelsa would be promising candidates as adjuvants in cisplatin-resistant cancer therapy $(179,180)$.

\section{SNP analysis to determine their role in cancer}

Complex SNP studies may be a way of personal risk assessment and could serve as a possible treatment predictive marker for chemotherapy in several cancer types $(45,105,125)$. Certain hereditary SNPs in cancer patients are assumed to increase the development of cancer, for instance, by inducing conformational changes in the encoded protein. Hoffmeyer et al. reported that the SNP nr. rs 1045642 of the $A B C B 1$ gene correlates with ABCB1 expression 
levels, hence, determines the rate of uptake of its substrates and disease outcome $(120,125)$. Furthermore, according to a recent paper, the overexpression of BCL2 and ABCB1 proteins may predict the inefficacy of paclitaxel-based chemoradiotherapy (121).

We examined five SNPs in four cancer-related genes to determine cancer risk. The correlation of anticancer therapies and the success of treatment are not discussed in this thesis because the sample size is not big enough to draw the inference in statistical analysis. Since, we focused on hereditary SNPs that have been already included in the genome of healthy volunteers and patients before cancer developed, genomic DNA was extracted from blood, but not from the cancer tissue itself. The patients were divided into two groups: gynecological cancer group (ovarian and cervical cancer, $n=31$ ), and a mixed cancer group $(n=57)$. A group of healthy volunteers $(n=99)$ was applied as control group. The following SNPs were examined: ABCB1 (rs2032582, rs1045642), P53 (rs1042522), BCL2 (rs4645878) and BAX (rs2279115) (172, 173).

Significant differences in $B A X$ genotype frequencies with allele $G \quad(P<0.01$, $\mathrm{OR}=3.561)$, or positive trend in $P 53$ genotype frequencies with allele $\mathrm{C}(P=0.05917$, $\mathrm{OR}=1.622$ ) were found between the mixed cancer group and the control group.

No significant differences in $A B C B 1$ and $B C L 2$ genotype frequencies were found between cancer patients and the control group. However, it has already been verified that these examined SNPs are in correlation with ABCB1 levels and uptake of its substrates and disease outcome $(120,125)$. In case of $A B C B 1$, strong linkage disequilibrium was measured between its two SNPs nr. rs2032582 and rs1045642 $\left(r^{2}=0.114\right)$.

The data obtained in our study suggest that the allelic variants of $B A X$ may be predictive of cancer development. However, in this preliminary study only a limited number of samples were included. Further investigation is required to determine the correlation between $A B C B 1$ other SNPs and cancer expanding to the determination of ABCB1 expression levels in chemotherapy-resistant cancer. 


\section{NEW SCIENTIFIC RESULTS RELATED TO THE THESIS}

\section{Immunocytochemistry}

We demonstrated that the cisplatin-resistant A2780cis cell line does not express any of the $\mathrm{ABCB} 1$ and MRP1 transporters, and any of the hormone receptors of estrogen and progesterone.

\section{Effects of compounds in A2780cis and MDR cancer cell lines}

\subsection{Antiproliferative effect}

Several compounds were found to be good proliferation inhibitors in A2780cis and MDR cell lines. Copper-steroid coordination complexes seem to be better inhibitors of cells proliferation than platinum-steroid coordination complexes in both A2780cis and MDR cell lines.

Numerous compounds were found to significantly inhibit cell proliferation of MDR cells including semisubstituted steroids, hydantoin derivatives, steroidal alkaloids and saponins and phenolic components.

\subsection{Reversal of drug resistance}

Several substituted steroids were effective in the MDR reversal experiments in A780cis and MDR cell lines. Some steroids $(\mathbf{2}, \mathbf{5}, \mathbf{6}, \mathbf{1 2}, \mathbf{2 2}, \mathbf{2 5}, \mathbf{2 7})$ were found to be effective proliferation inhibitors in both A2780cis and MDR cells. When comparing structure, it seems that the activity does not depend on the structure of the skeleton, but it is rather the nature and arrangement of the functional groups that determine the activity.

Numerous hydantoin derivatives and natural compounds (steroidal alkaloids and phenolic components, and saponins) reversed resistance of MDR mouse lymphoma cells.

\subsection{Interaction of selected compounds and anticancer agents}

None of the complexes were found to be in synergistic interaction with the anticancer agent cisplatin in A2780cis cells. In MDR cells, one the steroid-type molecules with androst-5-ene structure (11) was found to have a synergistic effect in combination with doxorubicin; compound 25 showed some synergism as well.

Eight hydantoin derivatives (AD-26, AD-29, RW-13, KF-2, BS-1, MN-3, RW-15b, JH-63) containing aromatic substituents and some tertiary amine fragments showed synergistic interaction with doxorubicin in MDR cells. 
The most active alkaloids in the combination experiments in MDR cells were veralosinine (A5) and veranigrine (A6). Both are hydrophobic compounds containing two or more planar aromatic rings and a tertiary nitrogen.

Methylprototribestin (S2) was found to be the only saponin that had some synergistic interaction with doxorubicin in MDR cells.

\subsection{Apoptosis induction}

None of the steroid-type platinum and copper complexes was able to induce apoptosis either in A2780cis or in MDR cells.

\section{SNP analysis to determine their role in cancer}

The SNP nr. rs2279115 in $B A X$ gene may be predictive of cancer development, allele G might increase the probability of developing cancer. In case of the other four SNPs of ABCB1, BCL2 and P53 genes, no significant differences were found between cancer patient and healthy volunteer groups. In case of $A B C B 1$, strong linkage disequilibrium was measured between its two SNPs nr. rs2032582 and rs1045642. 


\section{SUMMARY}

The most important object of this thesis was to identify drug resistance or multidrug resistance modulator compounds of synthetic and natural origin in the examined two cell line pairs: A2780/A2780cis human ovarian cancer and PAR/MDR mouse lymphoma and cell lines. The cisplatin-resistant A2780cis cell line is an appropriate model cell line to study cisplatin resistance. The following compounds were evaluated to inhibit cell proliferation and drug resistance, and to reveal the possible interaction between them and the anticancer drug cisplatin or doxorubicin: semisubstituted steroids and their platinum and copper complexes, hydantoin derivatives, steroidal alkaloids, saponins and phenolic components. Furthermore, the apoptosis inducer potentials of steroids and their complexes were also determined.

First of all, we demonstrated immunocytochemically by using specific monoclonal antibodies that the cisplatin-resistant A2780cis cell line does not express any of the ABCB1 or MRP1 ABC-type transporters, and any of the hormone receptors of estrogen or progesterone. In control experiments, the expression of ABCB1 was detected in MDR cell, and the expression of hormone receptors was verified in MCF-7 breast cancer cells.

Then, several sets of compounds were evaluated in flow cytometric experiments to determine the multidrug resistance modulators. Out of the examined compounds, numerous were found to be effective as inhibitors of proliferation and MDR as well. One compound of steroidal type molecules with androst-5-ene (11) structure was found to have synergistic effect in combination with doxorubicin in MDR cells, compound 25 showed low level of synergism. Three compounds $(\mathbf{4}, \mathbf{5}, \mathbf{2 5})$ and their platinum and copper complexes were selected to evaluate their effects on cancer cells. Copper-steroid complexes were found to be better inhibitor of proliferation in comparison with the non-complexed steroids or platinumsteroid complexes. None of these steroid complexes was in synergistic interaction with anticancer agent cisplatin or doxorubicin, and none of them was found to be apoptosis inducers in these two cancer cell lines. None of the examined steroids and their platinum and copper complexes was found to be effective apoptosis inducer either in A2780cis or in MDR cells. 
When considering the interaction between doxorubicin and the examined compounds in MDR cells, eight hydantoins derivatives (AD-26, AD-29, RW-13, KF-2, BS-1, MN-3, RW15b, JH-63), two alkaloids (A5, A6) and a saponin-type compound (S2) indicated synergism.

In the genetic experiments, we found significant correlation between an allelic variant of BAX SNP nr. rs2279115 between control and patient groups. We did not find significant differences in the other investigated SNPs of ABCB1, BCL2 and P53 genes, however, in this preliminary study only limited number of samples were included. Further investigation is required to determine the correlation between $A B C B 1$ other SNPs and cancer expanding to the determination of $\mathrm{ABCB} 1$ expression levels in chemotherapy-resistant cancer. 


\section{XII. ÖSSZEFOGLALÓ}

A disszertáció fő céljaként tűztük ki új, szintetikusan elöállított vagy természetben előforduló drogrezisztencia- illetve multidrogrezisztencia-módosítók azonosítását. Vizsgálatainkat kétféle sejtvonalpáron végeztük: A2780/A2780cis petefészekrák és PAR/MDR egér T-limfóma sejtvonalakon. A ciszplatinrezisztens A2780cis petefészekrák sejtvonal különösen alkalmas a ciszplatinrezisztens tumorok rezisztenciamechanizmusainak tanulmányozására. A következő anyagok hatását vizsgáltuk a sejtosztódás-gátlásra és a rezisztenciamódosító képességre, valamint kölcsönhatásukat doxorubicinnal és ciszplatinnal: félszintetikus szteroidok és azok rézzel és platinával alkotott komplexei, hidantoinszármazékok, szteroid típusú alkaloidok, szaponinok és fenolos vegyületek. Továbbá vizsgáltuk a szteroidok és komplexeik esetleges apoptózist indukáló hatását is.

Első lépésként a ciszplatinrezisztens A2780cis emberi petefészekrák sejtvonalat jellemeztük immuncitokémiai módszerrel, eredményeink szerint ez a sejtvonal sem az ABCB1, sem az MRP1 ABC típusú pumpákat nem expresszálja, valamint az ösztrogén és progeszteron receptorok jelenlétét sem tudtuk kimutatni monoklonális ellenanyagokkal. Kontrollkísérletekben bizonyítottuk a doxorubicin-rezisztens MDR sejtekben az ABCB1 expresszióját, illetve a hormonreceptorok expresszióját is sikerült kimutatni MCF-7 emlőrák sejtekben.

A továbbiakban néhány anyagcsoportot vizsgáltunk áramlási citometriás kísérletekben, mint lehetséges rezisztenciamódosítókat. A vizsgált anyagok közül számos mutatott szignifikáns rezisztenciavisszafordító aktivitást. Az egyik androszt-5-én szerkezetű szteroidmolekula (11) kombinációs kísérletekben MDR sejtvonalon szinergista hatást mutatott doxorubicinnal, egy másik anyag (25) esetében is valószínüsíthető a szinergista kölcsönhatás. A 35 szteroid típusú vegyület közül hármat $(\mathbf{4}, \mathbf{5}, \mathbf{2 5})$ vizsgáltunk réz, illetve platinakomplex formájában is, melyek közül a rézkomplexek jobb sejtosztódásgátlónak, illetve rezisztenciagátlónak bizonyultak mind a nem komplexált szteroidoknál, mind a platinakomplexeknél. A kombinációs kísérletekben egyik komplex esetében sem tudtunk kimutatni szinergista kölcsönhatást ciszplatinnal vagy doxorubicinnel, valamint egyik anyag sem bizonyult hatásos apoptózisinducernek. A vizsgált szteroid típusú vegyületek, és azok 
platina- és rézkomplexei közül egyik sem bizonyult apoptózisinducernek sem az A2780cis, sem az MDR sejtvonalakon.

Kombinációs kísérletekben nyolc hidantoinszármazék (AD-26, AD-29, RW-13, KF-2, BS-1, MN-3, RW-15b, JH-63), két alkaloid típusú (A5, A6) és egy szteroid típusú (S2) molekula mutatott szinergista hatást doxorubicinnel az MDR sejtvonal.

Az genetikai vizsgálatok során sikerült szignifikáns különbséget kimutatni a $B A X$ vizsgált polimorfizmusa tekintetében a kontroll és betegcsoportok között. A többi SNP esetében ( $A B C B 1, B C L 2$ és P53 génekben) azonban nem sikerült szignifikáns különbséget meghatározni, ennek egyik oka lehet a SNP vizsgálatokba bevont kis mintaelemszám. Újabb vizsgálatok szükségesek az $A B C B 1$ további egynukeotidos polimorfizmusai és a kemoterápiás kezelésre rezisztens ráktípusok közötti összefüggés meghatározására, amely vizsgálatok során az ABCB1 fehérje expressziós szintjének meghatározása is megtörténik. 


\section{REFERENCES}

1. World Cancer Report 2008. ISBN 9789283204237. Edited by Peter Boyle and Bernard Levin. World Health Organization, 2008.

2. KSH (Központi Statisztikai Hivatal, Hungarian Central Statistical Office) data table: Death statistics by the most frequent causes of deaths (Halálozások a leggyakoribb halálokok szerint 1990-), refreshed on 29th July 2011. Internet access at http://portal.ksh.hu/pls/ksh/docs/hun/xstadat/xstadat_eves/i_wnh001.html. Downloaded on 10th November 2011.

3. Ferlay, J.; Shin, H.R.; Bray, F.; Forman, D.; Mathers, C.; Parkin, D.M. GLOBOCAN 2008, Cancer Incidence and Mortality Worldwide: IARC CancerBase No. 10 [Internet]. Lyon, France: International Agency for Research on Cancer; 2010. Internet access at http://globocan.iarc.fr. Downloaded on $14^{\text {th }}$ November 2010.

4. Hanahan, D.; Weinberg, R.A. The hallmarks of cancer. Cell, 2000, 100: 57-70.

5. Hall, K.; Blair Zajdel, M.E.; Blair, G.E. Unity and diversity in the human adenoviruses: exploiting alternative entry pathways for gene therapy. Biochem. J., 2010, 431: 321-336.

6. Ayrton, A.; Morgan, P. Role of transport proteins in drug discovery and development: a pharmaceutical perspective. Xenobiotica, 2008, 38: 676-708.

7. Dean, M. ABC transporters, drug resistance, and cancer stem cells. J. Mammary Gland Biol. Neoplasia, 2009, 14: 3-9.

8. Howell, S.B.; Safaei, R.; Larson, C.A.; Sailor, M.J. Copper transporters and the cellular pharmacology of the platinum-containing cancer drugs. Mol. Pharmacol., 2010, 77: 887-894.

9. Bohlius, J.; Herbst, C.; Reiser, M.; Schwarzer, G.; Engert, A. Granulopoiesis-stimulating factors to prevent adverse effects in the treatment of malignant lymphoma. Cochrane Database Syst. Rev., 2008, 8, CD003189.

10. Tisdale, M.J. Mechanisms of cancer cachexia. Physiol. Rev., 2009, 89: 381-410.

11. Valera, E.T.; Scrideli, C.A.; Queiroz, R.G.; Mori, B.M.; Tone, L.G. Multiple drug resistance protein (MDR-1), multidrug resistance-related protein (MRP) and lung resistance protein (LRP) gene expression in childhood acute lymphoblastic leukemia. Sao Paulo Med. J., 2004, 122: 166-171.

12. Pieters, R.; Klumper, E.; Kaspers, G.J.; Veerman, A.J. Everything you always wanted to know about cellular drug resistance in childhood acute lymphoblastic leukemia. Crit. Rev. Oncol. Hematol., 1997, 25: 11-26.

13. Baird, R.D.; Kaye, S.B. Drug resistance reversal - are we getting closer? Eur. J. Cancer, 2003, 39: 24502461.

14. Gillet, J.P.; Gottesman, M.M. Mechanisms of multi-drug resistance in cancer. In: Multi-Drug Resistance in Cancer, J. Zhou (ed.). Methods Mol. Biol., 2010, 596: 47-76.

15. Gottesman, M.M. Mechanisms of cancer drug resistance. Annu. Rev. Med., 2002, 53: 615-627.

16. Gottesman, M.M.; Fojo, T.; Bates, S.E. Multidrug resistance in cancer: role of ATP-dependent transporters. Nat. Rev. Cancer, 2002, 2: 48-58.

17. Gillet, J.P.; Efferth, T.; Remacle, J. Chemotherapy-induced resistance by ATP-binding cassette transporter genes. Biochim. Biophys. Acta, 2007, 1775: 237-262.

18. Szakács, G.; Paterson, J.K.; Ludwig, J.A.; Booth-Genthe, C.; Gottesman, M.M. Targeting multidrug resistance in cancer. Nat. Rev. Drug. Discov., 2006, 5: 219-234.

19. Kuo, M.T.; Chen, H.H.W.; Song, I.; Savaraj, N.; Ishikawa, T. The roles of copper transporters in cisplatin resistance. Cancer Metastasis Rev., 2007, 26: 71-83. 
20. Shen, D; Pastan, I; Gottesman, M.M. Cross-resistance to methotrexate and metals in human cisplatinresistant cell lines results from a pleiotropic defect in accumulation of these compounds associated with reduced plasma membrane binding proteins. Cancer Res., 1998, 58: 268-275.

21. Shen, D.W.; Goldenberg, S.; Pastan, I.; Gottesman, M.M. Decreased accumulation of (14C)carboplatin in human cisplatin-resistant cells results from reduced energy-dependent uptake. J. Cell. Physiol., 2000, 183: $108-116$.

22. Oyama, T.; Kagawa, N.; Kunugita, N.; Kitagawa, K.; Ogawa, M.; Yamaguchi, T.; Suzuki, R; Kinaga, T.; Yashima, Y.; Ozaki, S.; Isse, T.; Kim, Y.D.; Kim, H.; Kawamoto, T. Expression of cytochrome P450 in tumor tissues and its association with cancer development. Front. Biosci., 2004, 9: 1967-1976.

23. Xie, H.; Griskevicius, L; Stahle, L.; Hassan, Z.; Yasar, U.; Rane, A.; Broberg, U.; Kimby E.; Hassan, M. Pharmacogenetics of cyclophosphamide in patients with hematological malignancies. Eur. J. Pharm. Sci., 2006, 27: 54-61.

24. Pegg, A.E. Repair of O(6)-alkylguanine by alkyltransferases. Mutat. Res., 2000, 462: 83-100.

25. Hakem, R. DNA-damage repair; the good, the bad, and the ugly. EMBO J., 2008, 27: 589-605.

26. Rodriguez-Nieto, S.; Zhivotovsky, B. Role of alterations in the apoptotic machinery in sensitivity of cancer cells to treatment. Curr. Pharm. Des., 2006, 12: 4411-4425.

27. Viktorsson, K.; Lewensohn, R.; Zhivotovsky, B. Apoptotic pathways and therapy resistance in human malignancies. Adv. Cancer Res., 2005, 94: 143-196.

28. Endicott, J.A.; Ling, V. The biochemistry of P-glycoprotein-mediated multidrug resistance. Annu. Rev. Biochem., 1989, 58: 137-171.

29. Takara, K.; Sakaeda, T.; Okumura, K. An update on overcoming MDR1-mediated multidrug resistance in cancer chemotherapy. Curr. Pharm. Des., 2006, 12: 273-286.

30. Litman, T.; Brangi, M.; Hudson, E.; Fetsch, P.; Abati, A.; Ross, D.D.; Miyake, K.; Resau, J.H.; Bates, S.E. The multidrug-resistant phenotype associated with overexpression of the new $\mathrm{ABC}$ half-transporter, MXR (ABCG2). J. Cell Sci., 2000, 113: 2011-2021.

31. Köberle, B.; Tomicic, M.T.; Usanova, S.; Kaina, B. Cisplatin resistance: preclinical findings and clinical implications. Biochim. Biophys. Acta, 2010, 1806: 172-182.

32. Ueda, K.; Okamura, N.; Hirai, M.; Tanigawara, Y.; Saeki, T.; Kioka, N.; Komano, T.; Hori, R. Human Pglycoprotein transports cortisol, aldosterone, and dexamethasone, but not progesterone. J. Biol. Chem., 1992, 267: 24248-24252.

33. Goff, B.A.; Ries, J.A.; Els, L.P.; Coltrera, M.D.; Gown, A.M. Immunophenotype of ovarian cancer as predictor of clinical outcome: evaluation at primary surgery and second-look procedure. Gynecol. Oncol., 1998, 70: 378-385.

34. Masuda, H.; Ozols, R.F.; Lai, G.M.; Fojo, A.; Rothenberg, M.; Hamilton, T.C. Increased DNA repair as a mechanism of acquired resistance to cis-diamminedichloroplatinum (II) in human ovarian cancer cell lines. Cancer Res., 1988, 48: 5713-5716.

35. Stewart, D.J. Mechanisms of resistance to cisplatin and carboplatin. Crit. Rev. Oncol. Hematol., 2007, 63: $12-31$.

36. Cascorbi, I. Role of pharmacogenetics of ATP-binding cassette transporters in the pharmacokinetics of drugs. Pharmacol. Ther., 2006, 112: 457-473.

37. Choudhuri, S.; Klaassen, C.D. Structure, function, expression, genomic organization, and single nucleotide polymorphisms of human ABCB1 (MDR1), ABCC1 (MRP), and ABCG2 (BCRP) efflux transporters. Int. J. Toxicol., 2006, 25: 231-259.

38. Efferth, T.; Volm, M. Pharmacogenetics for individualized cancer chemotherapy. Pharmacol. Ther., 2005, 107: $155-176$. 
39. Sharom, F.J. ABC multidrug transporters: structure, function and role in chemoresistance. Pharmacogenomics, 2008, 9: 105-127.

40. Ross, D.D.; Doyle, L.A. Mining our ABCs: pharmacogenomic approach for evaluating transporter function in cancer drug resistance. Cancer Cell, 2004, 6: 105-107.

41. Gillet, J.P.; Gottesman, M.M. Advances in the molecular detection of ABC transporters involved in multidrug resistance in cancer. Curr. Pharm. Biotechnol., 2011, 12: 686-692.

42. Wu, C.P.; Calcagno, A.M.; Ambudkar, S.V. Reversal of ABC drug transporter-mediated multidrug resistance in cancer cells: evaluation of current strategies. Curr. Mol. Pharmacol., 2008, 1: 93-105.

43. Gottesman, M.M.; Ambudkar, S.V. Overview: $\mathrm{ABC}$ transporters and human disease. J. Bioenerg. Biomembr., 2001, 33: 453-458.

44. Ambudkar, S.V.; Dey, S.; Hrycyna, C.A.; Ramachandra, M.; Pastan, I.; Gottesman, M.M. Biochemical, cellular and pharmacological aspects of the multidrug transporter. Annu. Rev. Pharmacol. Toxicol., 1999, 34: 361-398.

45. Ambudkar, S.V.; Kimchi-Sarfaty, C.; Sauna, Z.E.; Gottesman, M.M. P-glycoprotein: from genomics to mechanism. Oncogene, 2003, 22: 7468-7485.

46. Aszalos, A. Drug-drug interactions affected by the transporter protein, P-glycoprotein (ABCB1, MDR1) I. Preclinical aspects. Drug. Discov. Today, 2007, 12: 833-837.

47. Ambudkar, S.V.; Kim, I.W.; Sauna, Z.E. The power of the pump: mechanisms of action of P-glycoprotein (ABCB1). Eur. J. Pharm. Sci., 2006, 27: 392-400.

48. Chang, G.; Roth, C.B. Structure of MsbA from E. coli: a homolog of the multidrug resistance ATP binding cassette (ABC) transporters. Science, 2001, 293: 1793-1800.

49. Higgins, C.F.; Linton, K.J. The xyz of ABC transporters. Science, 2001, 293: 1782-1784.

50. Locher, K.P. Structure and mechanism of ABC transporters. Curr. Opin. Struct. Biol., 2004, 14: 426-431.

51. Higgins, C.F.; Linton, K.J. The ATP switch model for ABC transporters. Nat. Struct. Mol. Biol., 2004, 11: 918-926.

52. Dean, M.; Rzhetsky, A.; Allikmets, R. The human ATP-binding cassette (ABC) transporter superfamily. Genome Res., 2001, 11: 1156-66.

53. Thiebaut, F.; Tsuruo, T.; Hamada, H.; Gottesman, M.M.; Pastan, I.; Willingham, M.C. Cellular localization of the multidrug-resistance gene product P-glycoprotein in normal human tissues. Proc. Natl. Acad. Sci. U.S.A., 1987, 84: 7735-7738.

54. Mottino, A.D.; Catania, V.A. Hepatic drug transporters and nuclear receptors: regulation by therapeutic agents. World J. Gastroenterol., 2008, 14: 7068-7074.

55. Seelig, A. A general pattern for substrate recognition by P-glycoprotein. Eur. J. Biochem., 1998, 251: 252261.

56. Seelig, A.; Landwojtowicz, E. Structure-activity relationship of P-glycoprotein substrates and modifiers. Eur. J. Pharm. Sci., 2000, 12: 31-40.

57. Wang, R.B.; Kuo, C.L.; Lien, L.L.; Lien, E.J. Structure-activity relationship: Analyses of p-glycoprotein substrates and inhibitors. J. Clin. Pharm. Ther., 2003, 28: 203-228.

58. Zhou, S.F. Structure, function and regulation of P-glycoprotein and its clinical relevance in drug disposition. Xenobiotica, 2008, 38: 802-832.

59. Candussio, L.; Decorti, G.; Crivellato, E.; Granzotto, M.; Rosati, A.; Giraldi, T.; Bartoli, F. Toxicologic and pharmacokinetic study of low doses of verapamil combined with doxorubicin. Life Sci., 2002, 71: 3109-3119. 
60. Molnár, J.; Prágai, B.; Berencsi, K.; Mándi, Y.; Földeák, S. Comparative study of antiproliferative effects of chlorpromazine, 7,8-dioxochlorpromazine, amantadine-N-mustard, rutin-N-mustard and alpha, beta and gamma interferon on K 562 cells in vitro. Acta microbiol. Acad. Sci. Hung., 1985, 32: 377-384.

61. Molnár, J.; Taródi, B.; Gálfi, M.; Matkovics, B.; Motohashi, N. In vitro antiproliferative effects of tricyclic psychopharmaceutical agents and synergism with some resistance modifiers. Anticancer Res., 1992, 12: 273-280.

62. Motohashi, N.; Sasaki, Y.; Wakabayashi, Y.; Sakagami, H.; Molnár, J.; Kurihara, T. Relationship between pi-electron distribution and anticancer activity of benzo(a)phenothiazines. Anticancer Res., 1992, 12: $1423-1426$.

63. Ferreira, M.J.U.; Duarte, N.; Gyémánt, N.; Radics, R.; Cherepnev, G.; Varga, A.; Molnár, J. Interaction between doxorubicin and the resistance modifier stilbene on multidrug resistant mouse lymphoma and human breast cancer cells. Anticancer Res., 2006, 26: 3541-3546.

64. Molnár, J.; Gyémánt, N.; Tanaka, M.; Hohmann, J.; Bergmann-Leitner, E.; Molnár, P.; Deli, J.; Didiziapetris, R.; Ferreira, M.J.U. Inhibition of multidrug resistance of cancer cells by natural diterpenes, triterpenes and carotenoids. Curr. Pharm. Des., 2006, 12: 287-311.

65. Spengler, G.; Handzlik, J.; Ocsovszki, I.; Viveiros, M.; Kiec-Kononowicz, K.; Molnár, J.; Amaral, L. Modulation of multidrug efflux pump activity by new hydantoin derivatives on colon adenocarcinoma cells without inducing apoptosis. Anticancer Res., 2011, 31: 3285-3288.

66. Gately, D.P.; Howell, S.B. Cellular accumulation of the anticancer agent cisplatin: a review. Br. J. Cancer, 1993, 67: 1171-1176.

67. Safaei, R.; Holzer, A.K.; Katano, K.; Samimi, G.; Howell, S.B. The role of copper transporters in the development of resistance to Pt drugs. J. Inorg. Biochem., 2004, 98: 1607-1613.

68. Holzer, A.K.; Samimi, G.; Katano, K.; Naerdemann, W.; Lin, X.; Safaei, R.; Howell, S.B. The copper influx transporter human copper transport protein 1 regulates the uptake of cisplatin in human ovarian carcinoma cells. Mol. Pharmacol., 2004, 66: 817-823.

69. Kuo, M.T.; Chen, H.H.; Song, I.S.; Savaraj, N.; Ishikawa, T. The roles of copper transporters in cisplatin resistance. Cancer Metastasis. Rev., 2007, 26: 71-83.

70. Stewart, D.J. Mechanisms of resistance to cisplatin and carboplatin. Crit. Rev. Oncol. Hematol., 2007, 63: 12-31.

71. Samimi, G.; Safaei, R.; Katano, K.; Holzer, A.K.; Rochdi, M.; Tomioka, M.; Goodman, M.; Howell, S.B. Increased expression of the copper efflux transporter ATP7A mediates resistance to cisplatin, carboplatin and oxaliplatin in ovarian cancer cells. Clin. Cancer Res., 2004, 10: 4661-4669.

72. Kalayda, G.V.; Wagner, C.H.; Buss, I.; Reedijk, J.; Jaehde, U. Altered localisation of the copper efflux transporters ATP7A and ATP7B associated with cisplatin resistance in human ovarian carcinoma cells. BMC Cancer, 2008, 8: 175.

73. Rabik, C.A.; Maryon, E.B.; Kasza, K.; Shafer, J.T.; Bartnik, C.M.; Dolan, M.E. Role of copper transporters in resistance to platinating agents. Cancer Chemother. Pharmacol., 2009, 64: 133-142.

74. Abada, P.; Howell, S.B. Regulation of cisplatin cytotoxicity by $\mathrm{Cu}$ influx transporters. Met. Based Drugs, 2010, 2010: 317581 .

75. HUGO Gene Nomenclature Committee at the European Bioinformatics Institute. Available at http://www.genenames.org. Data downloaded on 1st March 2011.

76. Hediger, M.A.; Romero, M.F.;PPeng, J-B.; Rolfs, A.; Takanaga, H.; Bruford, E.A. The ABCs of solute carriers: physiological, pathological and therapeutic implications of human membrane transport proteins. Eur. J. Physiol., 2004, 447: 465-468.

77. Blair, B.G.; Larson, C.A.; Safaei, R.; Howell, S.B. Copper transporter 2 regulates the cellular accumulation and cytotoxicity of cisplatin and carboplatin. Clin. Cancer Res., 2009, 15: 4312-4321. 
78. Blair, B.G.; Larson, C.A.; Adams, P.L.; Abada, P.B.; Safaei, R; Howell, S.B. Regulation of copper transporter 2 expression by copper and cisplatin in human ovarian carcinoma cells. Mol. Pharmacol., 2010, 77: 912-921.

79. Barry, A.N.; Shinde, U.; Lutsenko, S. Structural organization of human Cu-transporting ATPases: learning from building blocks. J. Biol. Inorg. Chem., 2010, 15: 47-59.

80. Lewinson, O.; Lee, A.T.; Rees, D.C.A. P-type ATPase importer that discriminates between essential and toxic transition metals. Proc. Natl. Acad. Sci. U.S.A., 2009, 106: 4677-4682.

81. Suzuki, M.; Gitlin, J.D. Intracellular localization of the Menkes and Wilson's disease proteins and their role in intracellular copper transport. Pediatr. Int., 1999, 41: 436-442.

82. Murata, Y.; Kodama, H.; Abe, T.; Ishida, N.; Nishimura, M.; Levinson, B.; Gitschier, J.; Packman, S. Mutation analysis and expression of the mottled gene in the mascular mouse model of Menkes disease. Pediatr. Res., 1997, 42: 436-442.

83. Chelly, J.; Tümer, Z.; Tønnesen, T.; Petterson, A.; Ishikawa-Brush, Y.; Tommerup, N.; Horn, N.; Monaco, A.P. Isolation of a candidate gene for Menkes disease that encodes a potential heavy metal binding protein. Nat. Genet., 1993, 3: 14-19.

84. Mercer, J.F.; Livingston, J.; Hall, B.; Paynter, J.A.; Begy, C.; Chandrasekharappa, S.; Lockhart, P.; Grimes, A.; Bhave, M.; Siemieniak, D.; Glover, T.W. Isolation of a partial candidate gene for Menkes disease by positional cloning. Nat. Genet., 1993, 3: 20-25.

85. Vulpe, C.; Levinson, B.; Whitney, S.; Packman, S.; Gitschier, J. Isolation of a candidate gene for Menkes disease and evidence that it encodes a copper-transporting ATPase. Nat. Genet., 1993, 3: 7-13.

86. Tanzi, R.E.; Petrukhin, K.; Chernov, I.; Pellequer, J.L.; Wasco, W.; Ross, B.; Romano, D.M.; Parano, E.; Pavone, L.; Brzustowicz, L.M.; Devoto, M.; Peppercorn, J.; Bush' A.I.; Sternlieb, I.; Pirastu, M.; Gusella, J.F.; Evgrafov, O.; Penchaszadeh, G.K.; Honig, B.; Edelman, I.S.; Soares, M.B.; Scheinberg, I.H.; Gilliam, T.C. The Wilson disease gene is a copper transporting ATPase with homology to the Menkes disease gene. Nat. Genet., 1993, 5: 344-350.

87. La Fontaine, S.; Mercer, J.F. Trafficking of the copper-ATPases, ATP7A and ATP7B: role in copper homeostasis. Arch. Biochem. Biophys., 2007, 463: 149-167.

88. Veldhuis, N.A.; Gaeth, A.P.; Pearson, R.B.; Gabriel, K.; Camakaris, J. The multi-layered regulation of copper translocating P-type ATPases. Biometals, 2009, 22: 177-190.

89. Eisses, J.F.; Kaplan, J.H. Molecular characterization of hCTR1, the human copper uptake protein. J. Biol. Chem., 2002, 277: 29162-29171.

90. Safaei, R.; Howell, S.B. Copper transporters regulate the cellular pharmacology and sensitivity to Pt drugs. Crit. Rev. Oncol. Hematol., 2005, 53: 13-23.

91. Blair, B.G.; Larson, C.A.; Adams, P.L.; Abada, P.B.; Pesce, C.E.; Safaei, R.; Howell, S.B. Copper transporter 2 regulates endocytosis and controls tumor growth and sensitivity to cisplatin in vivo. Mol. Pharmacol., 2011, 79: 157-166.

92. van den Berghe, P.V.; Folmer, D.E.; Malingré, H.E.; van Beurden, E.; Klomp, A.E.; van de Sluis, B.; Merkx, M.; Berger, R.; Klomp, L.W. Human copper transporter 2 is localized in late endosomes and lysosomes and facilitates cellular copper uptake. Biochem. J., 2007, 407: 49-59.

93. Bertinato, J.; Swist, E.; Plouffe, L.J.; Brooks, S.P.; L'abbé, M.R. Ctr2 is partially localized to the plasma membrane and stimulates copper uptake in COS-7 cells. Biochem. J., 2008, 409: 731-740.

94. Barnes, N.; Tsivkovskii, R.; Tsivkovskaia, N.; Lutsenko, S. The copper-transporting ATPases, Menkes and Wilson disease proteins, have distinct roles in adult and developing cerebellum. J. Biol. Chem., 2005, 280: $9640-9645$.

95. Ishida, S.; Lee, J.; Thiele, D.J.; Herskowitz, I. Uptake of the anticancer drug cisplatin mediated by the copper transporter Ctr1 in yeast and mammals. Proc. Natl. Acad. Sci. U.S.A., 2002, 99: 14298-24302. 
96. Rixe, O.; Ortuzar, W.; Alvarez, M.; Parker, R.; Reed, E.; Paull, K.; Fojo, T. Oxaliplatin, tetraplatin, cisplatin, and carboplatin: spectrum of activity in drug-resistant cell lines and in the cell lines of the National Cancer Institute's Anticancer Drug Screen panel. Biochem. Pharmacol., 1996, 52: 1855-1865.

97. Nicholson, D.L.; Purser, S.M.; Maier, R.H. Differential cytotoxicity of trace metals in cisplatin-sensitive and -resistant human ovarian cancer cells. Biometals, 1998, 11: 259-263.

98. Gupta, A.; Lutsenko, S. Human copper transporters: mechanism, role in human diseases and therapeutic potential. Future Med. Chem., 2009, 1: 1125-1142.

99. Lee, J.; Pena, M.M.; Nose, Y.; Thiele, D.J. Biochemical characterization of the human copper transporter Ctr1. J. Biol. Chem., 2002, 277: 4380-4387.

100. Materia, S.; Cater, M.A.; Klomp, L.W.; Mercer, J.F.; La Fontaine, S. Clusterin (apolipoprotein J), a molecular chaperone that facilitates degradation of the copper-ATPases ATP7A and ATP7B. J. Biol. Chem., 2011, 286: 10073-10083.

101. Brookes, A.J. The essence of SNPs. Gene, 1999, 234: 177-186.

102. International HapMap Consortium. The International HapMap Project. Nature, 2003, 426: 789-796.

103. Packer, B.R.; Yeager, M.; Staats, B.; Welch, R.; Crenshaw, A.; Kiley, M.; Eckert, A.; Beerman, M.; Miller, E.; Bergen, A.; Rothman, N.; Strausberg, R.; Chanock, S.J. SNP500Cancer: a public resource for sequence validation and assay development for genetic variation in candidate genes. Nucleic Acids Res., 2004, 32: D528-532.

104. Halushka, M.K.; Fan, J.B.; Bentley, K.; Hsie, L.; Shen, N.P.; Weder, A.; Cooper, R.; Lipshutz, R.; Chakravarti, A. Patterns of single nucleotide polymorphisms in candidate genes for blood pressure homeostasis. Nat. Genet., 1999, 22: 239-247

105. Kimchi-Sarfaty, C.; Oh, J.M.; Kim, I-W.; Kim, I.W.; Sauna, Z.E.; Calcagno, A.M.; Ambudkar, S.V.; Gottesman, M.M. A silent polymorphism in the MDR1 gene changes substrate specificity. Science, 2007, 315: 525-528.

106. Jun, G.; Guo. H.; Klein, B.E.; Klein, R.; Wang, J.J.; Mitchell, P.; Miao, H.; Lee, K.E.; Joshi, T.; Buck, M.; Chugha, P.; Bardenstein, D.; Klein, A.P.; Bailey-Wilson, J.E.;Gong, X.; Spector, T.D.; Andrew, T.; Hammond, C.J.; Elston, R.C.; Iyengar, S.K.; Wang, B. EPHA2 Is Associated with age-related cortical cataract in mice and humans. PLoS Genet., 2009, 5: e1000584.

107. Vieira, S.M.; Monteiro, M.B.; Marques, T.; Luna, A.M.; Fortes, M.A.; Nery, M.; Queiroz, M.; Dib, S.A.; Vendramini, M.F.; Azevedo, M.J.; Canani, L.H.; Parisi, M.C.; Pavin, E.J.; Giannella-Neto, D.; CorrêaGiannella, M.L. Association of genetic variants in the promoter region of genes encoding p22phox (CYBA) and glutamate cysteine ligase catalytic subunit (GCLC) and renal disease in patients with type 1 diabetes mellitus. BMC Med.Genet., 2011, 12: 129.

108. Chung, C.C.; Chanock, S.J. Current status of genome-wide association studies in cancer. Hum. Genet., 2011, 130: 59-78.

109. Nacsa, J.; Nagy, L.; Hevér, A.; Szabó, D.; Ocsovszki, I.; Molnár, J. The reversal of multidrug resistance and SOS-responses by metal coordination complexes of tricyclic compounds. $4^{\text {th }}$ International Symposium on Cytostatic Drug Resistance. Berlin, 27-29 $9^{\text {th }}$ September 1997. Conference proceeding: page 84.

110. McNaught, A.D.; Wilkinson, A (Eds.). IUPAC. Compendium of Chemical Terminology, 2nd ed. (the "Gold Book"). Blackwell Scientific Publications, Oxford, 1997. XML on-line corrected version: http://goldbook.iupac.org (2006-) created by Nic, M.; Jirat, J. and Kosata; B., updates compiled by Jenkins, A. ISBN 0-9678550-9-8. Last update 11th October 2011.

111. Guo, Z.; Sadler, P.J. Metals in Medicine. Angew. Chem. Int. Ed., 1999, 38: 1512-1531.

112. Lovejoy, K.S.; Todd, R.C.; Zhang, S.; McCormick, M.S.; D'Aquino, J.A.; Reardon, J.T.; Sancar, A.; Giacomini, K.M.; Lippard, S.J. Cis-Diammine(pyridine)chloroplatinum(II), a monofunctional platinum(II) antitumor agent: Uptake, structure, function, and prospects. Proc. Natl. Acad. Sci. U.S.A., 2008, 105: 8902-8907. 
113. van Rijt, S.H.; Sadler, P.J. Current applications and future potential for bioinorganic chemistry in the development of anticancer drugs. Drug. Discov. Today, 2009, 14: 1089-1097.

114. Aird, R.E.; Cummings, J.; Ritchie, A.A.; Muir, M.; Morris, R.E.; Chen, H.; Sadler, P.J.; Jodrell, D.I. In vitro and in vivo activity and cross resistance profiles of novel ruthenium(II) organometallic arene complexes in human ovarian cancer. Br. J. Cancer, 2002, 86: 1652-1657.

115. Barnard, P.J.; Berners-Price, S.J. Targeting the mitochondrial cell death pathway with gold compounds. Coord. Chem. Rev., 2007, 251: 1889-1902.

116. Powis, G.; Kirkpatrick, D.L. Thioredoxin signaling as a target for cancer therapy. Curr. Opin. Pharmacol., 2007, 7: 392-397.

117. Pilato, B.; Martinucci, M.; Danza, K.; Pinto, R.; Petriella, D.; Lacalamita, R.; Bruno, M.; Lambo, R.; D'Amico C, Paradiso, A.; Tommasi, S. Mutations and polymorphic BRCA variants transmission in breast cancer familial members. Breast Cancer Res. Treat., 2011, 125: 651-657.

118. Liber, A.F. Ovarian cancer in a mother and five daughters. Arch. Pathol., 1950, 49: 280-290.

119. Joó, J.G.; Ládi, S.; Nagy, B.Z.; Langmár, Z. Management of hereditary ovarian cancer. Orv Hetil., 2011, 152: 1596-1608.

120. Hoffmeyer, S.; Burk, O.; von Richter, O.; Arnold, H.P.; Brockmöller, J.; Johne, A.; Cascorbi, I.; Gerloff, T.; Roots, I.; Eichelbaum, M.; Brinkmann, U. Functional polymorphisms of the human multidrugresistance gene: multiple sequence variations and correlation of one allele with P-glycoprotein expression and activity in vivo. Proc. Natl. Acad. Sci. U.S.A., 2000, 97: 3473-3478.

121. Maráz, A.; Furák, J.; Pálföldi, R.; Eller, J.; Szántó, E.; Kahán, Z.; Thurzó, L.; Molnár, J.; Tiszlavicz, L.; Hideghéty, K. Roles of BCL-2 and MDR1 expression in the efficacy of paclitaxel-based lung cancer chemoradiation. Anticancer Res., 2011, 31: 1431-1436.

122. Saffari, B.; Bernstein, L.; Hong, D.C.; Sullivan-Halley, J.; Runnebaum, I.B.; Grill, H.J.; Jones, L.A.; ElNaggar, A.; Press, M.F. Association of p53 mutations and a codon 72 single nucleotide polymorphism with lower overall survival and responsiveness to adjuvant radiotherapy in endometrioid endometrial carcinomas. Int. J. Gynecol. Cancer, 2005, 15: 952-963.

123. Gadducci, A.; Di Cristofano, C.; Zavaglia, M.; Giusti, L.; Menicagli, M.; Cosio, S.; Naccarato, A.G.; Genazzani, A.R.; Bevilacqua, G.; Cavazzana, A.O. P53 gene status in patients with advanced serous epithelial ovarian cancer in relation toresponse to paclitaxel- plus platinum-based chemotherapy and long-term clinicaloutcome. Anticancer Res., 2006, 26: 687-693.

124. Gréen, H.; Söderkvist, P.; Rosenberg, P.; Horvath, G.; Peterson, C. Mdr-1 single nucleotide polymorphisms in ovarian cancer tissue: G2677T/A correlates with response to paclitaxel chemotherapy. Clin. Cancer Res., 2006, 12: 854-859.

125. Chen, K.; Hu, Z.; Wang, L.E.; Sturgis, E.M.; El-Naggar, A.K.; Zhang, W.; Wei, Q. Single-nucleotide polymorphisms at the TP53-binding or responsive promoter regions of $B A X$ and BCL2 genes and risk of squamous cell carcinoma of the head and neck. Carcinogenesis, 2007, 28: 2008-2012.

126. Pastan, I.; Gottesman, M.M.; Ueda, K.; Lovelace, E.; Rutherford, A.V.; Willingham, M.C. A retrovirus carrying an MDR1 cDNA confers multidrug resistance and polarized expression of P-glycoprotein in MDCK cells. Proc. Natl. Acad. Sci. U.S.A., 1988, 85: 4486-4490.

127. Choi K.; Frommel T.O.; Stern, R.K.; Perez C.F.; Kriegler M.; Tsuruo T. Roninson I.B. Multidrug resistance after retroviral transfer of the human $A B C B 1$ gene correlates with P-glycoprotein density in the plasma membrane and is not affected by cytotoxic selection. Proc. Natl. Acad. Sci. U.S.A., 1991, 88: 7386-7390.

128. Hamilton, T.C.; Young, R.C.; Ozols, R.F. Experimental model systems of ovarian cancer: applications to the design and evaluation of new treatment approaches. Sem. Oncol., 1984, 11: 285-298.

129. Behrens, B.C.; Hamilton, T.C.; Masuda, H.; Grotzinger, K.R.; Whang-Peng, J.; Louie, K.G.; Knutsen, T.; McKoy, W.M.; Young, R.C. Ozols, R.F. Characterization of a cis-diamminedichloroplatinum(II)- 
resistant human ovarian cancer cell line and its use in evaluation of platinum analogues. Cancer Res., 1987, 47: 414-418.

130. Honbu, T.; Ikeda, T.; Zhu, X.; Yoshihara, O.; Okawa, M.; Nafady, A.M.; Nohara, T. New steroidal glycosides from the fruits of Solanum anguivi. J. Nat. Prod., 2002, 65: 1918-1920.

131. Nguyen, V.T.B.; Darbour, N.; Bayet, C.; Doreau, A.; Raad, I.; Phung, B.H.; Dumontet, C.; Di Pietro, A.; Dijoux-Franca, M.; Guilet, D. Selective modulation of P-glycoprotein activity by steroidal saponines from Paris polyphylla. Fitoterapia, 2009, 80: 39-42.

132. Romo, J.; Rodriguez-Hahn L.; Jimenez M. Synthesis of steroidal pyrimidine N-oxides. Can. J. Chem., 1968, 46: 2807-2815.

133. Vincze, I.; Somlai, Cs.; Schneider, Gy.; Dombi, Gy.; Mák, M. Steroids, .XLV. Neighbouring group participation. 12. decomposition of (Z)-16-amidomethylene-17-beta-hydroxysteroids mediated by neighbouring group participation. Liebigs Ann. Chem., 1992, 187-192.

134. Szendi, Z.; Dombi, Gy. Vincze, I. Steroids, LIII: New routes to aminosteroids. Monatsh. Chem., 1996, 127: 1189-1196.

135. Forgó, P.; Vincze, I. Synthesis and advanced NMR structure determination of androsteno-[17,16-d]pyrimidine derivatives. Steroids, 2002, 67: 749-756.

136. Stodola, F.H.; Kendall, E.C.; McKenzie, B.F. Studies on steroid $\alpha$-ketols. II. A new partial synthesis of 5androstene-3, 16, 17-triol: an intermediate in th epreparation of 16-hydroxytestosterone. J. Org. Chem., 1941, 6: 841-846.

137. Vincze, I.; Lőkös, M.; Bakos, T.; Dancsi, A.; Mák, M. Steroids 49. Investigations on the dehydration of

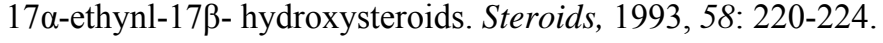

138. Weisz-Vincze, I.; Kovács, Ö.; Deák, Á. The base-catalysed reaction of androst-5-en-3ß-ol-17-one with formaldehyde. Eur. J. Steroids, 1967, 2: 139-156.

139. Clinton, R.O.; Manson, A.J.; Stonner, F.W.; Neumann, H.C.; Christiansen, R.G.; Clarke, R.L.; Ackerman, J.H.; Page, D.F.; Dean, J.W.; Dickinson, W.B.; Carabateas C. Steroidal[3,2-c]pyrazoles. II.1 Androstanes, 19-norandrostanes and their unsaturated analogs. J. Am. Chem. Soc., 1961, 83: 1478-1491.

140. Vincze, I.; Somlai, Cs.; Schneider, Gy.; Dombi, Gy.; Kálmán, A. 2-(hydroxymethyl)androstene derivatives. Liebigs Ann. Chem., 1987, 499-504.

141. Thenmozhiyal, J.C.; Wong, P.T.; Chui, W.K. Anticonvulsant activity of phenylmethylenehydantoins: a structure-activity relationship study. J. Med. Chem., 2004, 47: 1527-1535.

142. Dylag, T.; Zygmunt, M.; Maciag, D.; Handzlik, J.; Bednarski, M.; Filipek, B.; Kieć-Kononowicz K. Synthesis and evaluation of in vivo activity of diphenylhydantoin basic derivatives. Eur. J. Med. Chem., 2004, 39: 1013-1027.

143. Rajic, Z.; Zorc, B.; Raic-Malic, S.; Ester, K.; Kralj, M.; Pavelic, K.; Balzarini, J.; De Clercq, E.; Mintas, M. Hydantoin derivatives of L- and D-amino acids: synthesis and evaluation of their antiviral and antitumoral activity. Molecules, 2006, 11: 837-848.

144. Zuliani, V; Carmi, C.; Rivara, M.; Fantini, M; Lodola, A.; Vacondio, F.; Bordi, F; Plazzi, P.V.; Cavazzoni, A.; Galetti, M.; Alfieri, R.R.; Petronini, P.G.; Mor, M. 5-Benzylidene-hydantoins: synthesis and antiproliferative activity on A549 lung cancer cell line. Eur. J. Med. Chem., 2009, 44: 3471-3479.

145. Ananda Kumar, C.S.; Prasad, S.B.; Vinaya, K.; Chandrappa, S.; Thimmegowda, N.R.; Ranganatha, S.R.; Swarup, S.; Rangappa, K.S. Synthesis and antiproliferative activity of substituted diazaspiro hydantoins: a structure-activity relationship study. Invest. New Drugs, 2009, 27: 131-139.

146. Kavitha, C.V.; Nambiar, M.; Ananda Kumar, C.S.; Choudhary, B.; Muniyappa, K.; Rangappa, K.S.; Raghavan, S.C. Novel derivatives of spirohydantoin induce growth inhibition followed by apoptosis in leukemia cells. Biochem. Pharmacol., 2009, 77: 348-363.

147. Momekov, G.Ts.; Ugrinova, I.; Pasheva, E.A.; Bakalova, A.G.; Varbanov, H.P.; Ferdinandov, D.V.; Ivanov, D.S.; Konstantinov, S.M. In vitro biochemical and pharmacological evaluation of a novel 
cytotoxic dinuclearplatinum(II) complex with 3-amino-5-methyl-5-phenylhydantoin. Ann. N. Y. Acad. Sci., 2009, 1171: 649-658.

148. Bakalova, A.; Buyukliev, R.; Tcholakova, I.; Momekov, G.; Konstantinov, S.; Karaivanova, M.; Synthesis, physicochemical investigation and cytotoxic activity of new Pt(II) complexes with hydantoin ligands. Eur. J. Med. Chem., 2003, 38: 627-632.

149. Ting, Z.; Chang-Hong, W.; Zheng-Tao, W. Chemical constituents and pharmacological actions of genus Peganum: research advences. J. Int. Pharm. Res., 2010, 37: 333-345.

150. Lee, K.; Tanaka, M.; Kanamaru, H.; Hashimura, T.; Yamamoto, I.; Konishi, J.; Kuze, F. In vitro antagonism between cisplatin and vinca alkaloids. Br. J. Cancer, 1989, 59: 36-41.

151. Wei-Feng, W.; Wei-Jie, Z.; Shi-Sheng, W. Recent progress in steroidal alkaloids from Veratrum. The Proceedings of the 3rd International Conference on Functional Molecules, 2005, p. 4-7.

152. Christov, V.; Mikhova, B.; Selenge, D. Veranigrine, a new steroidal alkaloid from Veratrum nigrum L. Fitoterapia, 2009, 80: 25-27.

153. Babalakova, N.; Mikhova, B.; Christov, V.; Rocheva, S.; Javzan, S.; Selenge, D. Alkaloids from Peganum nigelastrum roots and their effects on the growth and organogenesis of cucumber. Compt. Rend. Acad. Bulg. Sci., 2011, 64: 45-52.

154. Osbourn, A.; Goss, R.J.; Field, R.A. The saponins: polar isoprenoids with important and diverse biological activities. Nat. Prod. Rep., 2011, 28: 1261-1268.

155. Francis, G.; Kerem, Z.; Makkar, H.P.; Becker, K. The biological action of saponins in animal systems: a review. Br. J. Nutr., 2002, 88: 587-605.

156. Ivanova, A.; Mikhova, B.; Klaiber, I.; Dinchev, D.; Kostova, I. Steroidal saponins from Smilax excelsa rhizomes. Nat. Prod. Res., 2009, 23: 916-924.

157. Ivanova, A.; Mikhova, B.; Kostova, I.; Evstatieva, L. Bioactive chemical constituents from Smilax excelsa. Chem Nat. Comp., 2010, 46: 295-297.

158. Kostova, I.; Dinchev, D.; Rentsch, G.H.; Dimitrov, V.; Ivanova, A. Two new sulfated furostanol saponins from Tribulus terrestris. Z. Naturforsch. C, 2002, 57: 33-38.

159. Dinchev, D.; Janda, B.; Evstatieva, L.; Oleszek, W.; Aslani, M.R.; Kostova, I. Distribution of steroidal saponins in Tribulus terrestris from different geographical regions. Phytochemistry, 2008, 69: 176-186.

160. Conrad, J.; Dinchev, D.; Klaiber, I., Mika, S.; Kostova, I.; Kraus, W. A novel furostanol saponin from Tribulus terrestris of Bulgarian origin. Fitoterapia, 2004, 75: 117-122.

161. Hoyer, G.A.; Sucrow, W.; Winkler, D. Diosgenin saponins from Dioscorea floribunda. Phytochemistry, 1975, 14: 539-542.

162. Espejo, O.; Llavot, C.; Jung, H.; Giral, F. Spirostanic diosgenin precursors from Dioscorea composita tubers. Phytochemistry, 1982, 21: 413-416.

163. Mashchenko, N.E.; Gyulemetova, R.; Kintya, P.K.; Shashkov, A.S. A sulfated glycoside from the preparation 'tribestan'. Khim. Prirod. Soed., 1990, 5: 649-652.

164. Mosmann, T. Rapid colorimetric assay for cellular growth and survival: Application to proliferation and cytotoxicity assays. J. Immunol. Methods, 1983, 65: 55-63.

165. Kars, M.D.; Iseri, O.D.; Gündüz, U.; Ural, A.U.; Arpaci, F.; Molnár, J. Development of rational in vitro models for drug resistance in breast cancer and modulation of MDR by selected compounds. Anticancer Res., 2006, 26: 4559-4568.

166. Eliopoulos, G.M.; Moellering R.C. Antimicrobial combinations. In: Lorian, V., Editor. Antibiotics in Laboratory Medicine (3rd edition.), Lippincott Williams \& Wilkins, Baltimore, MD, U.S.A. 1991, pp. 432-492.

167. Odds, F.C. Synergy, antagonism, and what the chequerboard puts between them. J. Antimicrob. Chemother., 2003, 52: 1. 
168. Fadok, V,A,; Voelker, D.R.; Campbell, P.A.; Cohen, J.J.; Bratton, D.L.; Henson, P.M. Exposure of phosphatidylserine on the surface of apoptotic lymphocytes triggers specific recognition and removal by macrophages. J. Immunol., 1992, 148: 2207-2216.

169. Martin, S.J.; Reutelingsperger, C.P.; McGahon, A.J.; Rader, J.A.; van Schie, R.C.; LaFace, D.M.; Green, D.R. Early redistribution of plasma membrane phosphatidylserine is a general feature of apoptosis regardless of the initiating stimulus: inhibition by overexpression of Bcl-2 and Abl. J Exp. Med., 1995, 182: $1545-1556$.

170. Satoh, K.; Sakagami, H.; Motohashi, N. Radical modulation activity of benzo[a]phenothiazine. Anticancer Res., 1997, 17: 2539-2543.

171. Miller, S.A.; Dykes, D.D.; Polesky, H.F. A simple salting out procedure for extracting DNA from human nucleated cells. Nucleic Acids Res., 1988, 16: 1215-1218.

172. Cascorbi, I.; Gerloff, T.; Johne, A.; Meisel, C.; Hoffmeyer, S.; Schwab. M; Schaeffeler, E.; Eichelbaum, M.; Brinkmann, U.; Roots, I. Frequency of single nucleotide polymorphisms in the P-glycoprotein drug transporter MDR1 gene in white subjects. Clin. Pharmacol. Ther., 2001, 69: 169-74.

173. Chen, K.; Hu, Z.; Wang, L.E.; Sturgis, E.M.; El-Naggar, A.K.; Zhang, W.; Wei, Q. Single-nucleotide polymorphisms at the TP53-binding or responsive promoter regions of $B A X$ and BCL2 genes and risk of squamous cell carcinoma of the head and neck. Carcinogenesis, 2007, 28: 2008-2012.

174. Sasieni, P.D. From genotypes to genes: doubling the sample size. Biometrics, 1997, 53: 1253-12561.

175. Dupont, W.D.; Plummer, W.D. Power and sample size calculations: A review and computer program. Control. Clin. Trials, 1990, 11: 116-128.

176. Musunuru, K.; Kathiresan S. HapMap and mapping genes for cardiovascular disease. Circ. Cardiovasc. Genet., 2008, 1: 66-71.

177. Klopman, G.; Srivastava, S.; Kolossvary, I.; Epand, R.F.; Ahmed, N.; Epand, R.M. Structure-activity study and design of multidrug-resistant reversal compounds by computer automated structure evaluation methodology. Cancer Res., 1992, 52: 4121-4129.

178. Zamora, J.M.; Pearce, H.L.; Beck, W.T. Physical-chemical properties shared by compounds that modulate multidrug resistance in human leukemic cells. Mol. Pharmacol., 1988, 33: 454-462.

179. Liu, H.Z.; Yu, C.; Yang, Z.; He, J.L.; Chen, W.J.; Yin, J.; Li, W.M.; Liu, H.T.; Wang, Y.X. Tubeimoside I sensitizes cisplatin in cisplatin-resistant human ovarian cancer cells (A2780/DDP) through downregulation of ERK and up-regulation of p38 signaling pathways. Mol. Med. Report, 2011, 4: 985-992.

180. Xu, Y.; Chiu, J.F.; He, Q.Y.; Chen, F. Tubeimoside-1 exerts cytotoxicity in HeLa cells through mitochondrial dysfunction and endoplasmic reticulum stress pathways. J. Proteome Res., 2009, 8: 1585-1593. 


\section{ACKNOWLEDGEMENT}

I wish to thank my supervisor, Professor József Molnár for the opportunity to work in his group at the Department of Medical Microbiology and Immunobiology. Furthermore, I wish to thank for his valuable comments and inspiration. The supportive work environment created by him considerably contributed to the success of my work.

I would like to express my greatest gratitude to Professor Yvette Mándi for the possibility to work in her Department of Medical Microbiology and Immunobiology.

I would like to acknowledge to Professor Irén Vincze, to Dr. Csaba Somlai and to Dr. Imre Labádi for their contribution to the steroid work.

I would like to thank to Professor Leonard Amaral and Professor Maria José Umbelino Ferreira from the University of Lisbon, and to Professor Neven Zarkovic from the University of Zagreb the opportunity to work in their laboratories as a guest early-stage researcher.

Here, I would like to acknowledge for the DNA samples to Dr.Veronika Szekeres (Regional Transfusion Centre of the Hungarian National Blood Transfusion Service, University of Szeged), Dr. Katalin Tápai (Regional Transfusion Centre of the Hungarian National Blood Transfusion Service, University of Szeged), Dr. Beatrix Nagy (Department of Oncology, Keszthely City Hospital), Dr. Éva Szilágyi (Division A, Department of Oncotherapy, University of Szeged) and Dr. László Hodoniczki (Division B, Department of Oncotherapy, University of Szeged).

I am really grateful to Dr. Rupert Quinnell, my English co-supervisor from the University of Leeds for the opportunity to work in his lab at the Institute of Integrative and Comparative Biology within the confines of a short-term Marie Curie scholarship.

I would like to thank Dr. Imre Ocsovszki for the flow cytometric experiments, and to Dr. Krisztina Boda for her help in the statistical calculation.

I wish to thank to Dr. Ilona Mucsi for the kind talks, for which I am really grateful as well to my colleagues, namely to Dr. Gabriella Spengler, Dr. Ana Martins, Dr. Cátia Ramalhete, Mariana Reis and Zoltán Gábor Varga, who gave me not only their wholehearted support in work but they are friends of mine, too. I really thank to Anikó Vigyikánné Váradi and Mariann Ábrahám for their technical help and for the deep talks 
during coffee breaks. Here, I wish to thank to my colleagues and staff members at the Department of Medical Microbiology and Immunobiology for creating a supportive and pleasant environment.

Finally, I would like to thank to all my friends and family for their selfless help and support during my whole life.

\section{FINANCIAL SUPPORT}

This thesis was supported financially by the following organizations and grants:

○ TÁMOP 4.2.1/B-09/1/KONV-2010-0005 (European Union, European Social Fund, University of Szeged)

National Innovation Office grants, contract nr. OMFB-1004/2007 and OMFB$00389 / 2008$

O Marie Curie fellowship of the European Union

O National Institute of Oncology

Foundation for Cancer Research Szeged 


\section{APPENDIX}

1. Semisubstituted steroids (I).
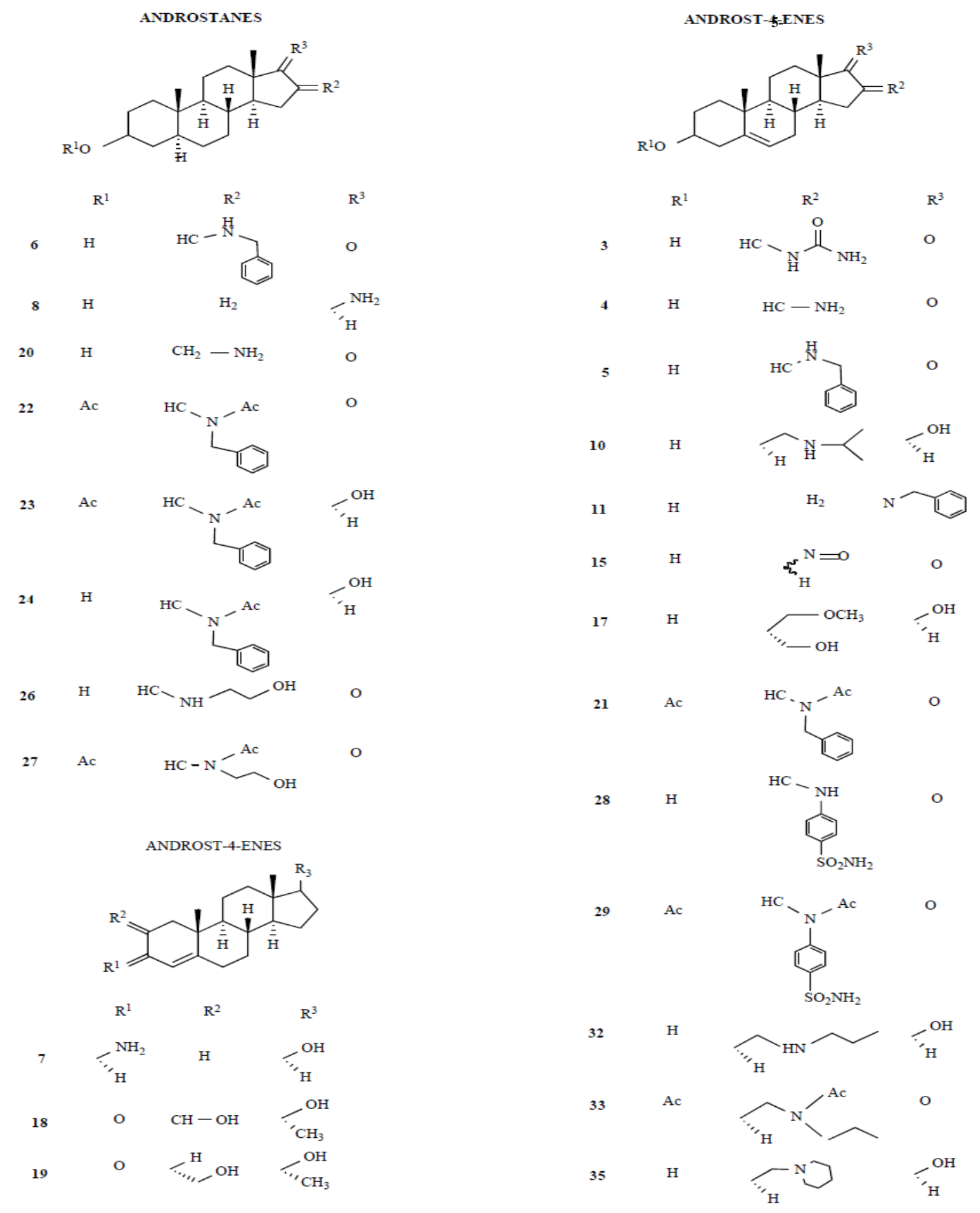


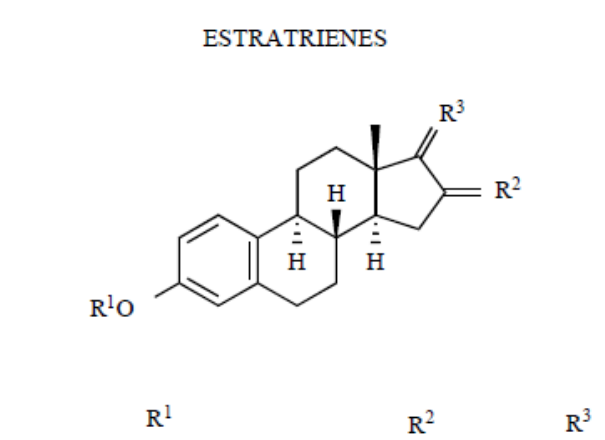

PREGNANES AND -ENES

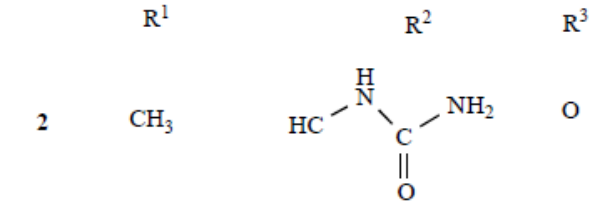

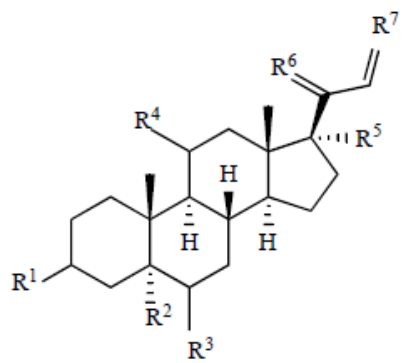

$25 \mathrm{CH} 3 \quad \mathrm{HC}^{-}{ }^{\mathrm{N}} \overbrace{\mathrm{OH}} \mathrm{O}$

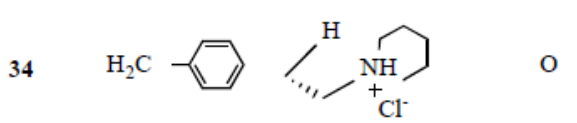

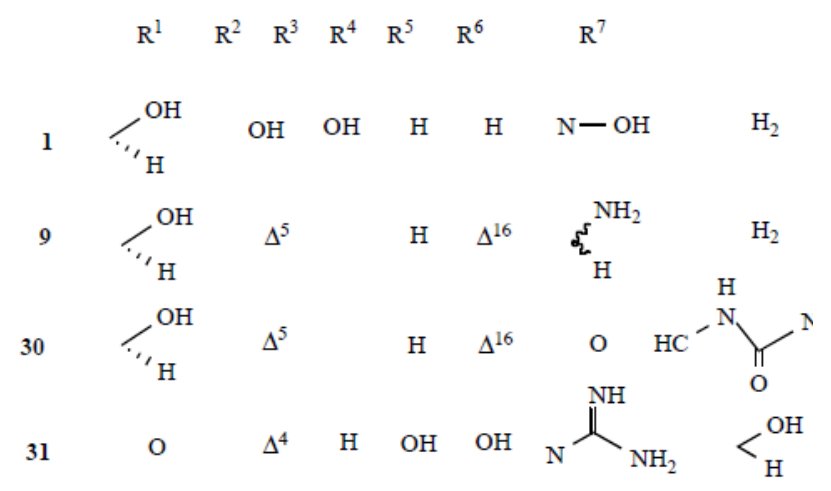

SPECIAL D-RING DERIVATIVES

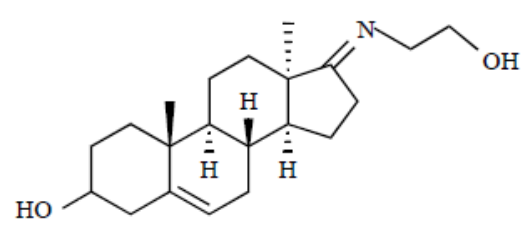

12

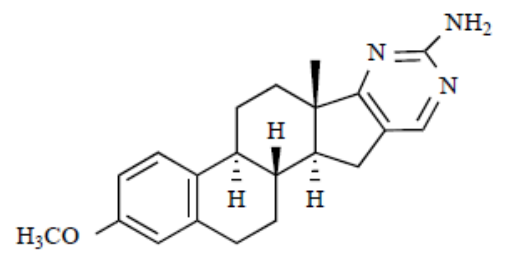

14

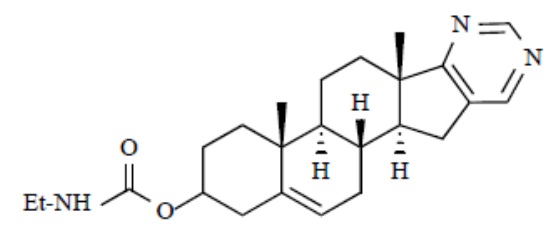

13<smiles>Cc1ccc2c(c1C)CC[C@H]1[C@@H]3CCC(=O)C=C3CC[C@H]21</smiles>

16

2. Basic structure of hydantoins (II).<smiles>O=C1CNC(=O)N1</smiles> 


\section{Alkaloids of Veratrum and Peganum species (III, IV).}

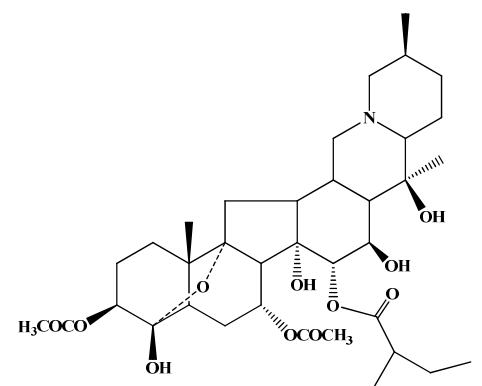

neogermitrine (1)

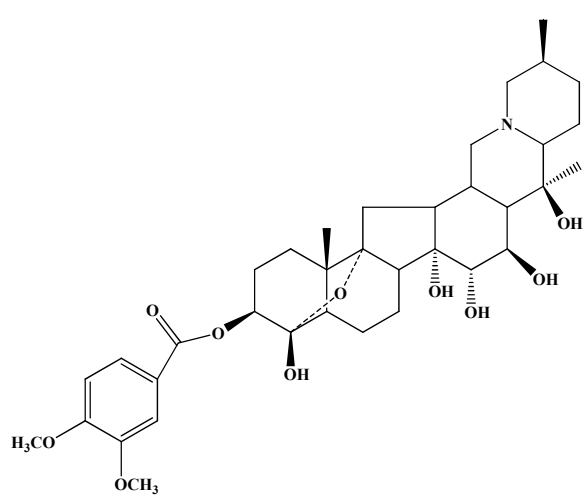

veratroilzigadenine (3)

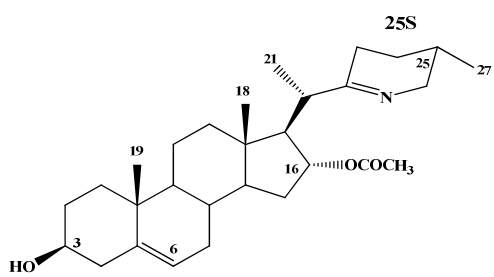

veralosinine (5)<smiles>O=c1c2ccccc2nc2n1CCC2</smiles>

deoxypeganine (7)

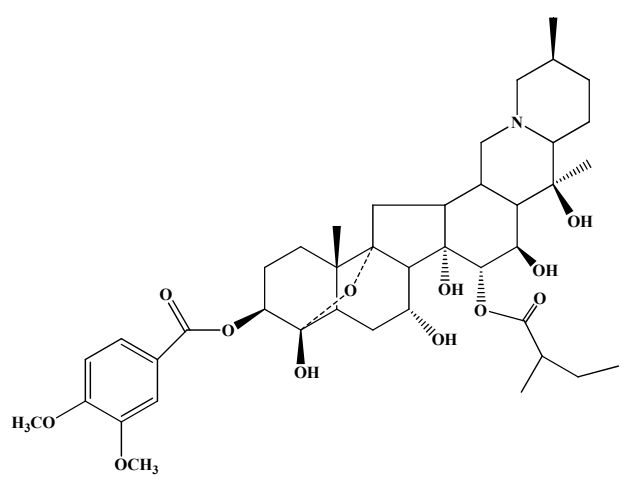

verabenzoamine (2)

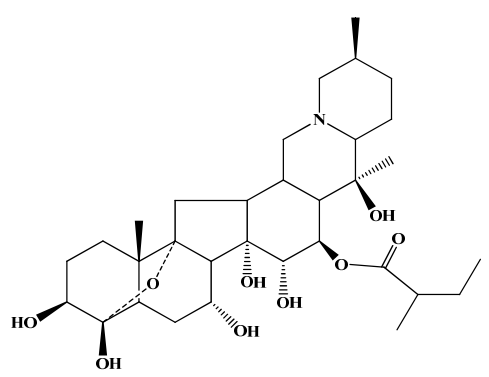

15-O-(2-methylbutyroyl)germine (4)

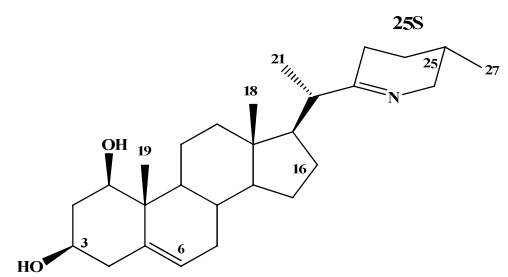

veranigrine (6)<smiles>COc1ccc2c(c1)[nH]c1c(C)nccc12</smiles>

harmine (8)<smiles>C=C1c2ccccc2N=C2C(O)CCN12</smiles>

peganine (9) 
4. Steroidal saponins and phenolic components of Tribulus terrestris and Smilax excelsa (V).

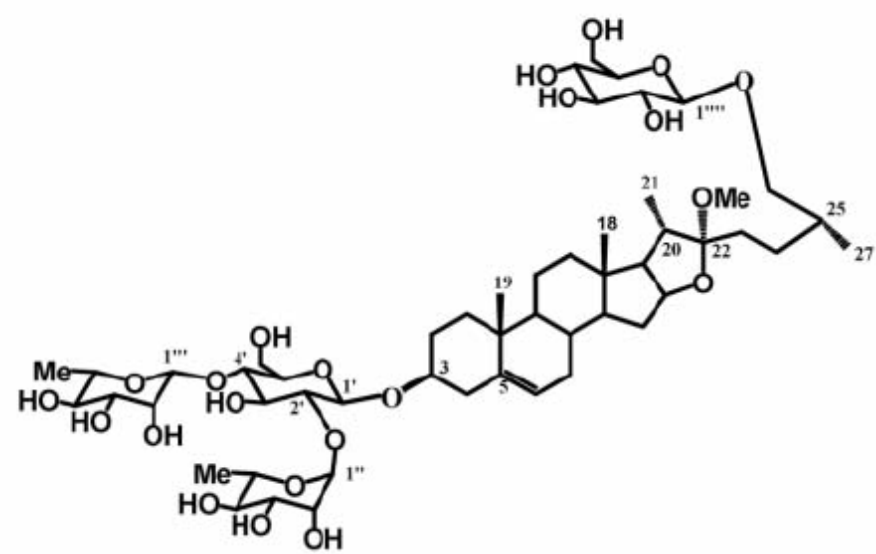

Methylprotodioscin (1)

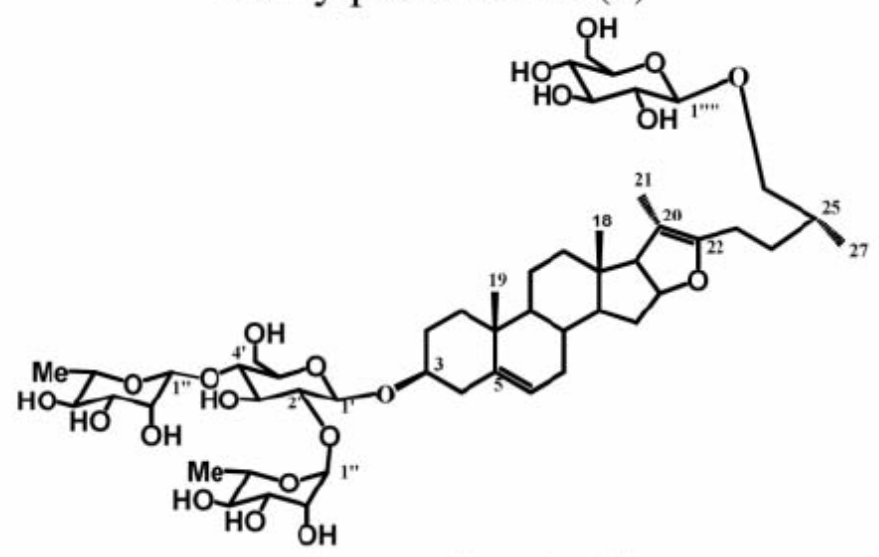

Pseudoprotodioscin (3)

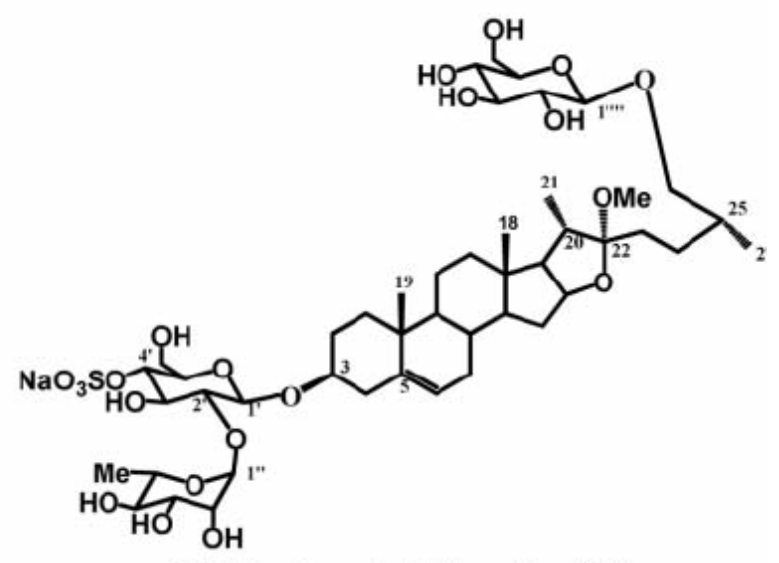

Methylprototribestin (2)

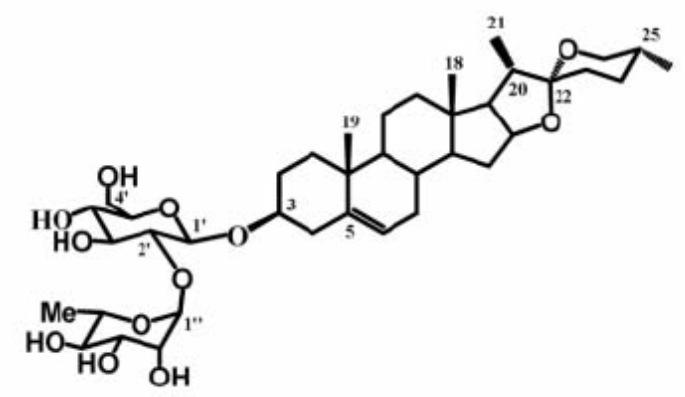

Prosapogenin A of dioscin (4)

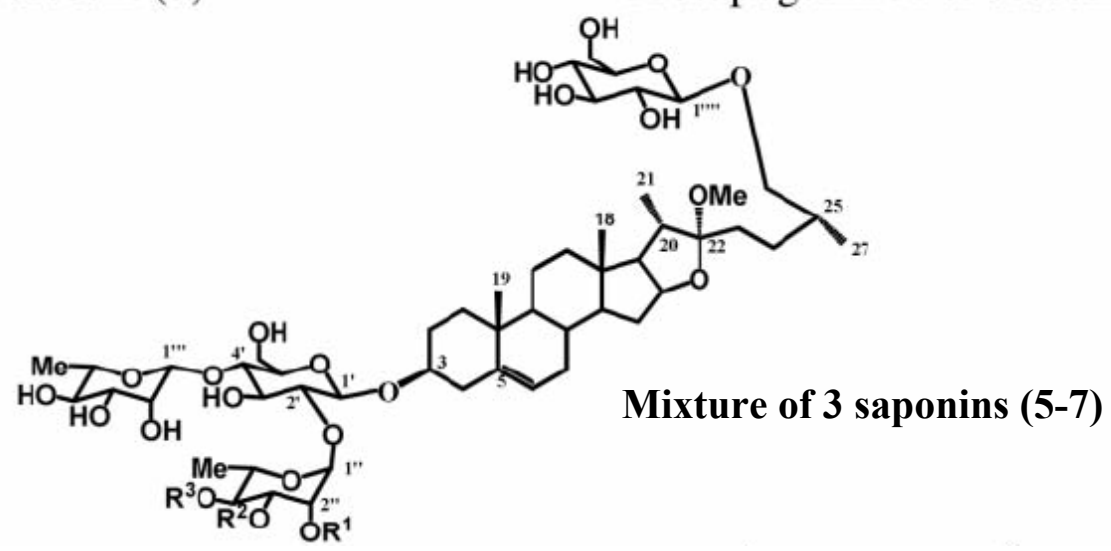

\begin{tabular}{c|c|c|c} 
& $\mathrm{R} 1$ & $\mathrm{R} 2$ & $\mathrm{R} 3$ \\
\hline $\mathbf{5}$ & OCOMe & $\mathrm{H}$ & $\mathrm{H}$ \\
\hline $\mathbf{6}$ & $\mathrm{H}$ & OCOMe & $\mathrm{H}$ \\
\hline $\mathbf{7}$ & $\mathrm{H}$ & $\mathrm{H}$ & OCOMe
\end{tabular}




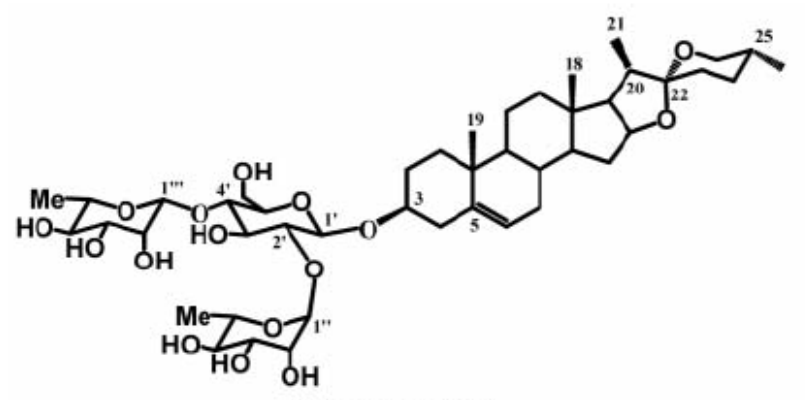

Dioscin (8)<smiles>O=C(/C=C/c1ccc(O)c(O)c1)OC1CC(C(=O)O)=CC(O)=C1O</smiles>

5-O-Caffeoylshikimic acid (10)

5. Verapamil<smiles>COc1ccc(CCN(C)CCCC(C#N)(c2ccc(OC)c(OC)c2)C(C)C)cc1OC</smiles>

7. Platinum-based chemotherapeutic agents

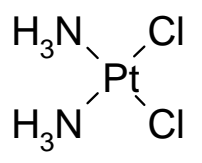

cisplatin<smiles>O=C1O[P]2(NC3CCCCC3N2)OC1=O</smiles>

oxaliplatin

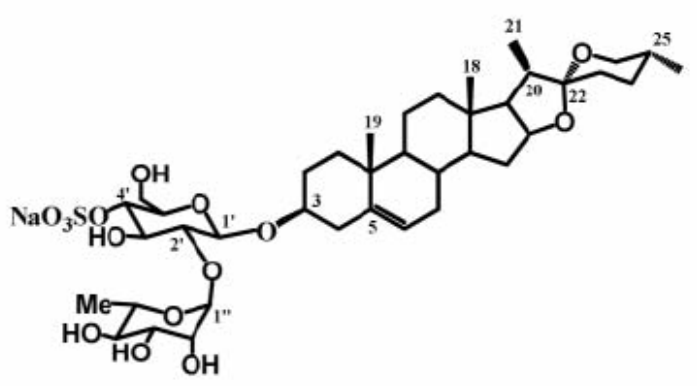

Tribestin (9)<smiles>CC(C)(C)Oc1cc(O)cc(/C=C/c2cc(O)cc(O)c2)c1</smiles>

6. Rhodamine 123<smiles>CC(=O)c1ccccc1C1=C2C=CNC=C2Oc2cnccc21</smiles>

\section{Doxorubicin}

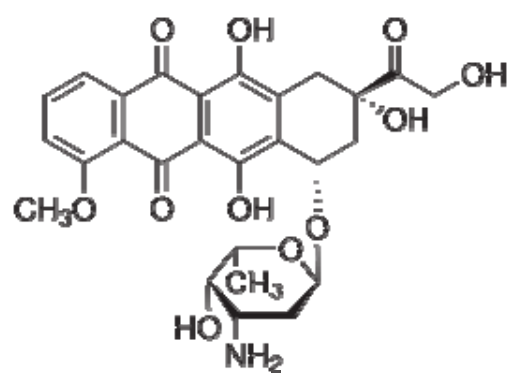<smiles>c1ccc2c(c1)Nc1c(ccc3ccccc13)S2</smiles> 
XVII. PUBLICATIONS 


\section{Publications related to the thesis}

I. Serly, J.; Vincze, I.; Somlai, Cs.; Hodoniczki, L.; Molnár, J. Synthesis and comparison of the antitumor activities of steroids on ABCB1-transfected mouse lymphoma and human ovary carcinoma. Lett. Drug Des. Dis., 2011, 8: 138-147. IF: 0.668

II. Spengler, G.; Evaristo, M.; Handzlik, J.; Serly, J.; Molnár, J.; Viveiros, M.; KiecKononowicz, K.; Amaral, L. Biological activity of hydantoin derivatives on Pglycoprotein (ABCB1) of mouse lymphoma cells. Anticancer Res., 2010, 30: $4867-$ 4871.

IF: 1.656

III. Christov, V.; Mikhova, B.; Ivanova, A.; Serly, J.; Molnár, J.; Selenge, D.; Solongo, A.; Kostova, N.; Gerelt-Od, Y.; Dimitrov, D. Steroidal alkaloids of Veratrum lobelianum Bernh. and Veratrum nigrum L. Z. Naturforsch. C., 2010, 65c: 195-200. IF: 0.718

IV. Ivanova, A.; Serly, J.; Christov, V.; Stamboliyska, B.; Molnár, J. Alkaloids derived from genus Veratrum and Peganum of Mongolian origin as multidrug resistance inhibitors of cancer cells. Fitoterapia, 2011, 85: 570-575.

IF: 1.899

V. Ivanova, A.; Serly, J.; Dinchev, D.; Ocsovszki, I.; Kostova, I.; Molnár, J. Screening of some saponins and phenolic components of Tribulus terrestris and Smilax excelsa as MDR modulators. In Vivo, 2009, 23: 545-550. 


\section{Publications not directly related to the thesis}

I. Molnár, J.; Serly, J.; Pusztai, R.; Vincze, I.; Molnár, P.; Horváth, Gy.; Deli, J.; Maoka, T.; Zalatnai, A.; Enjo, F.; Tokuda, H.; Nishino, H. Putative supramolecular complexes formed by carotenoids and ascorbic acid to reverse multidrug resistance in cancer cells. Anticancer Res., 2012, 32: XXX, accepted.

IF:1.656

II. Parekh, S.; Bhavsar, D.; Savant, M.; Thakrar, S.; Bavishi, A.; Parmar, M.; Vala, H.; Radadiya, A.; Pandya, N.; Serly, J.; Molnár, J.; Shah, A. Synthesis of some novel benzofuran-2-yl(4,5-dihyro-3,5-substituted diphenylpyrazol-1-yl) methanones and studies on the antiproliferative effects and reversal of multidrug resistance of human MDR1-gene transfected mouse lymphoma cells in vitro. Eur. J. Med. Chem., 2011, 46: 1942-1948.

IF: 3.193

III. Ivanova, A.; Batovska, D.; Todorova, I.; Stamboliyska, B.; Serly, J.; Molnár, J. Comparative study on the MDR reversal effects of selected chalcones. Int. J. Med. Chem., 2011, DOI:10.1155/2011/5307800.

IV. Cindric, M.; Cipak, A.; Serly, J.; Plotniece, A.; Jaganjac, M.; Mrakovcic, L.; Lovakovic, T.; Dedic, A.; Soldo, I.; Duburs, G.; Zarkovic, N.; Molnár, J. Reversal of multidrug resistance in murine lymphoma cells by amphiphilic dihydropyridine antioxidant derivative. Anticancer Res., 2010, 30: 4063-4069.

IF: 1.656

V. Pusztai, R.; Abrantes, M.; Serly, J.; Duarte, N.; Molnár, J.; Ferreira, M.J.U. Anti-tumorpromoting activity of lignans: inhibition of human cytomegalovirus IE gene expression. Anticancer Res., 2010, 30: 451-454.

IF: 1.656

VI. Spengler, G.; Ramalhete, C.; Martins, M.; Martins, A.; Serly, J.; Viveiros, M.; Molnár, J.; Duarte, N.; Mulhovo, S; Ferreira, M.J.U.; Amaral, L. Evaluation of cucurbitane-type triterpenoids from Momordica balsamina on P-glycoprotein (ABCB1) by flow cytometry and real-time fluorometry. Anticancer Res., 2009, 29: 3989-3994. IF: 1.428 
VII. Das, S.; Das, U.; Selvakumar, P.; Sharma, R.K.; Balzarini, J.; De Clercq, E.; Molnár, J.; Serly, J.; Baráth, Z.; Schatte, G.; Bandy, B.; Gorecki, D.K.J.; Dimmock, J.R. 3,5Bis(benzylidene)-4-oxo-1-phosphonopiperidines and related diethyl esters: potent cytotoxins with multi-drug-resistance reverting properties. ChemMedChem, 2009, 4: 1831-1840.

IF: 3.232

VIII.Szolnoki, Z.; Serly, J.; Kondacs, A.; Mándi, Y.; Somogyvári, F. Evaluation of the genetic variants of kinesin motor protein in ischemic stroke. J. Stroke Cerebrovasc. Dis., 2009, 18: 360-362.

IX. Somogyvári, F.; Dóczi, I.; Serly J.; Ahmad, S.; Nagy, E. Rapid discrimination between Candida albicans and Candida dubliniensis by using real-time PCR. Diagn. Microbiol. Infect. Dis., 2007, 58: 367-369.

IF: 2.448 